\title{
Pollinator communities and plant-pollinator interactions in fragmented calcareous grasslands
}

\author{
Dissertation \\ zur Erlangung des Doktorgrades \\ der Fakultät für Agrarwissenschaften \\ der Georg-August-Universität Göttingen
}

vorgelegt von

Birgit Meyer

geboren in Varel

Göttingen, Juli 2007 
D 7

1. Referent: Prof. Dr. Ingolf Steffan-Dewenter

2. Korreferent: Prof. Dr. Stefan Vidal

Tag der mündlichen Prüfung: 19.07.07 


\section{CONTENTS}

CHAPTER 1: PolLiNATORS IN AGRICULTURAL LANDSCAPES.................................................. 1

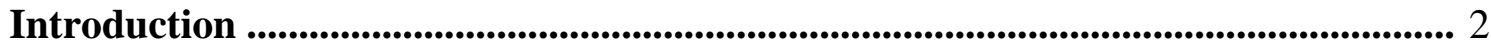

Study region and study sites .................................................................................. 3

Research objectives........................................................................................................ 6

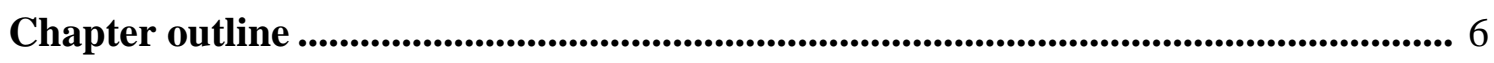

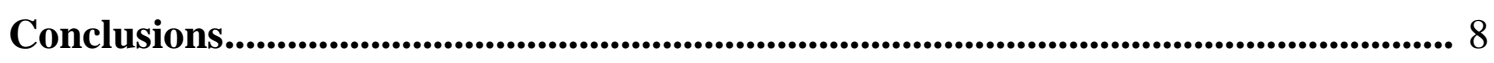

CHAPTER 2: IMPORTANCE OF LIFE HISTORY TRAITS FOR POLLINATOR LOSS

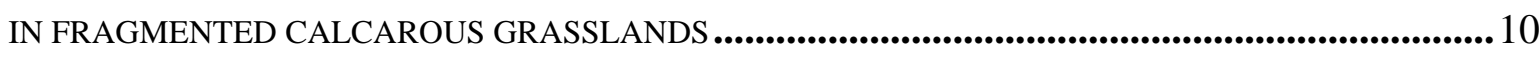

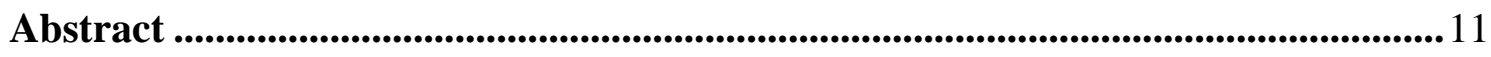

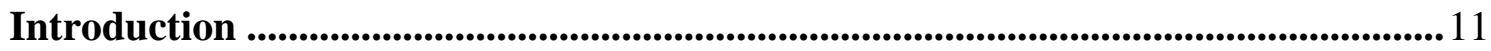

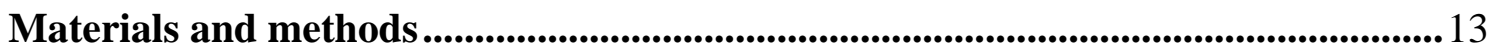

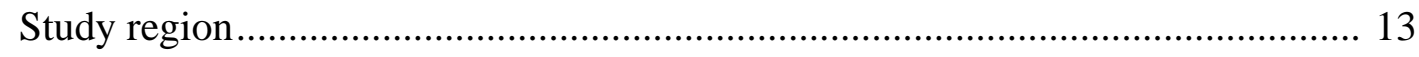

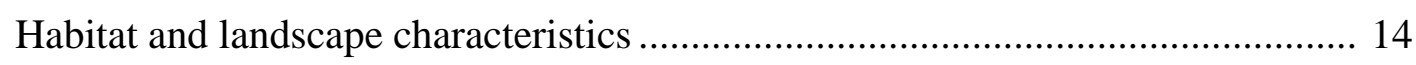

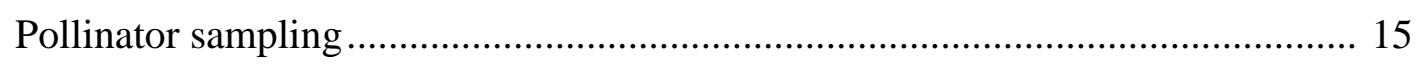

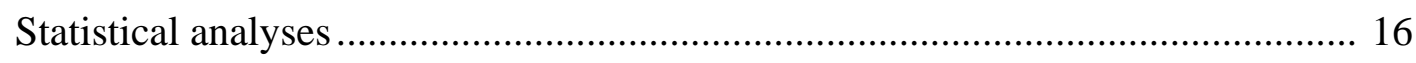

Results .................................................................................................................................................. 17

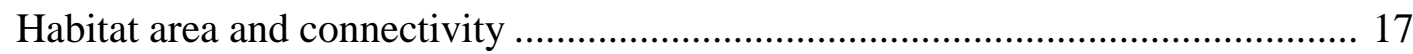

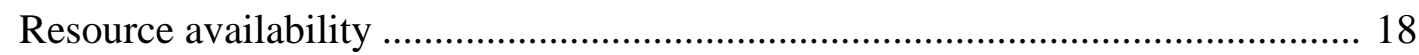

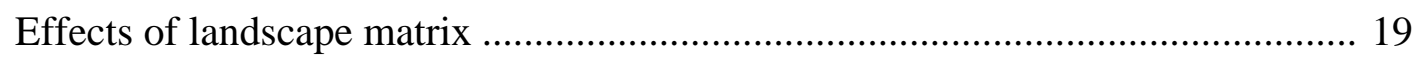

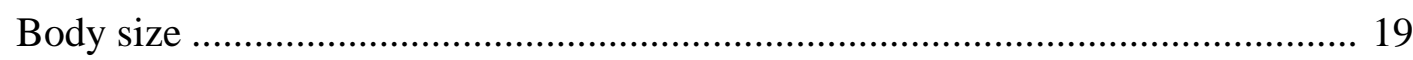

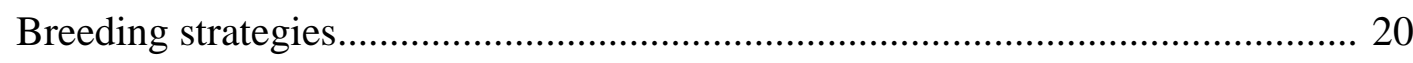

Discussion ................................................................................................................................. 21

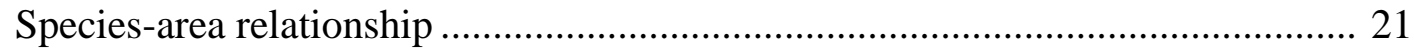

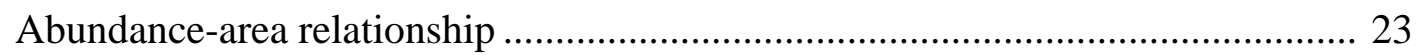

Effects of body size on species-area relationships .............................................. 23

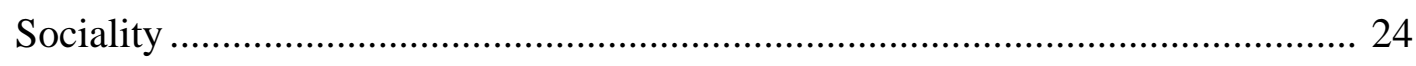

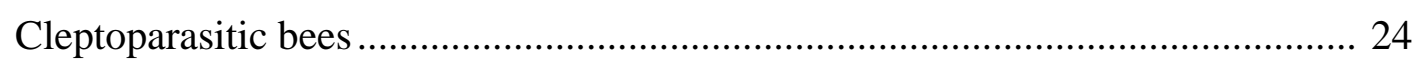

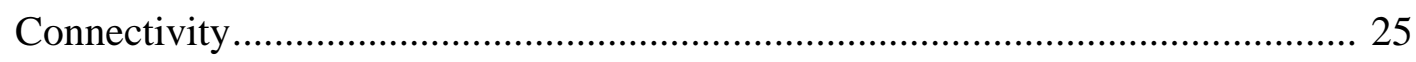

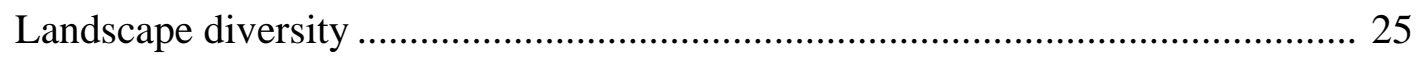

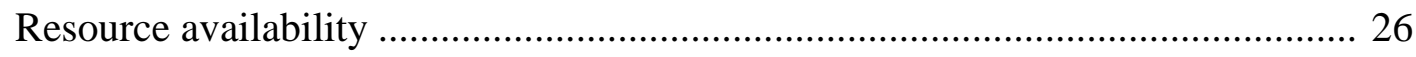

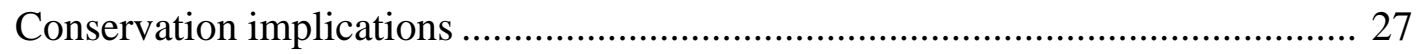


CHAPTER 3: CONTRASTING RESPONSES OF SPECIES RICHNESS AND DENSITY

OF HOVERFLIES (DIPTERA: SYRPHIDAE) TO AGRICULTURAL LAND-USE CHANGE ................... 30

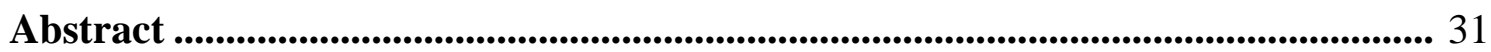

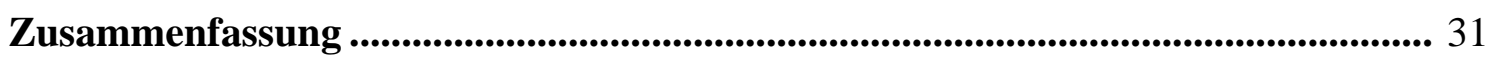

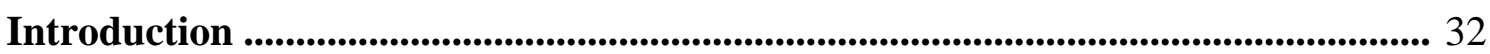

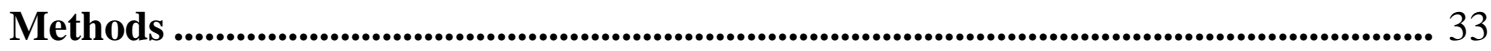

Study region and site characteristics................................................................... 33

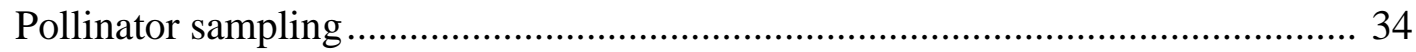

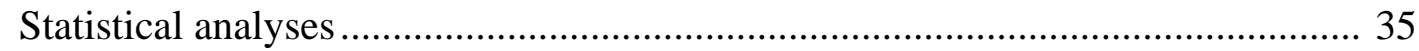

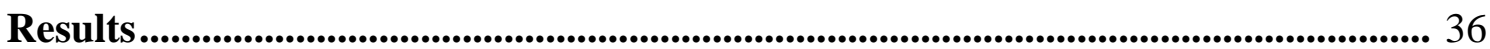

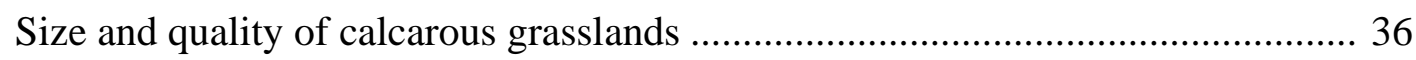

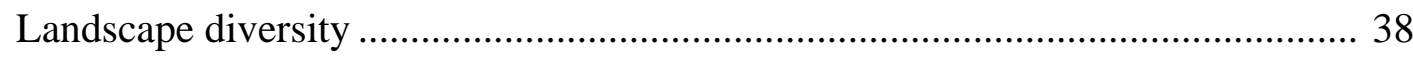

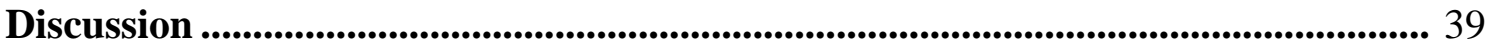

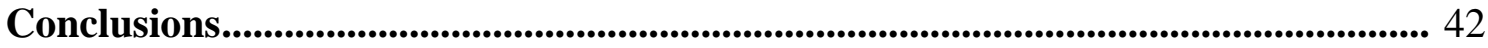

CHAPTER 4: LINKING FLOWER VISITATION, SEED SET, AND SEED PREDATION

OF PRIMULA VERIS AT MULTIPLE SPATIAL SCALES ............................................................. 45

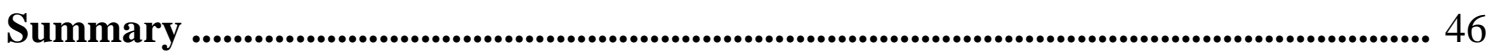

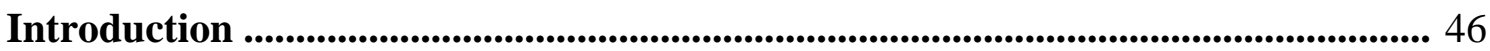

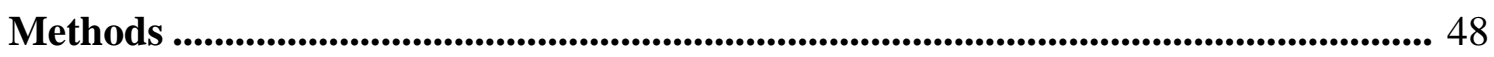

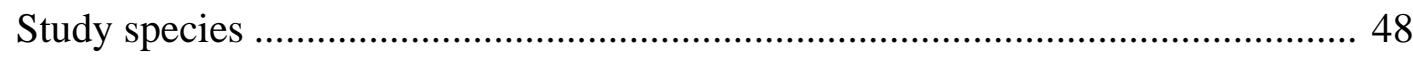

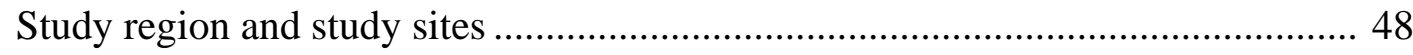

Flower visitation observation, pollen supplementation, and seed collection ......... 49

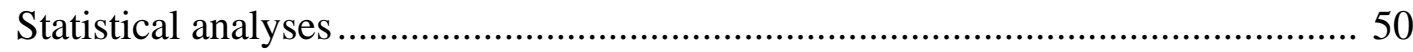

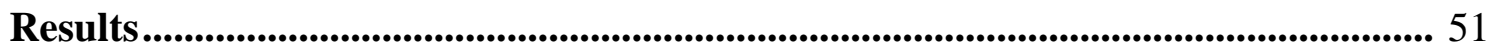

Pollinator abundance and diversity ........................................................... 51

Seed set and pollination limitation ............................................................... 54

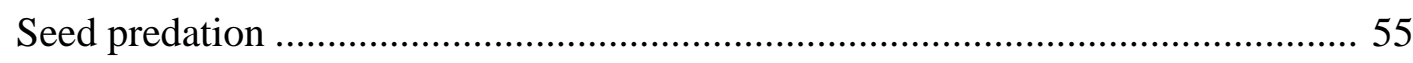

Discussion ................................................................................................................................................ 55

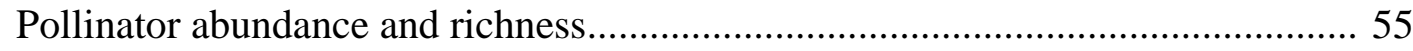

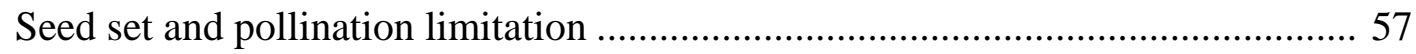

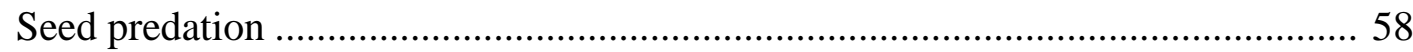

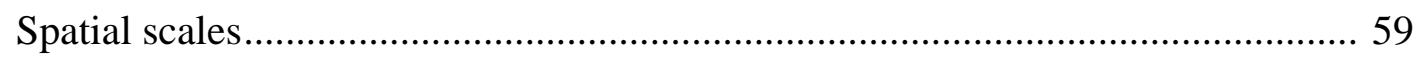


CHAPTER 5: PATCH AND LANDSCAPE EFFECTS ON POLLINATOR DIVERSITY AND SEED SET OF HIPPOCREPIS COMOSA IN AN AGRICULTURAL LANDSCAPE .............................................. 61

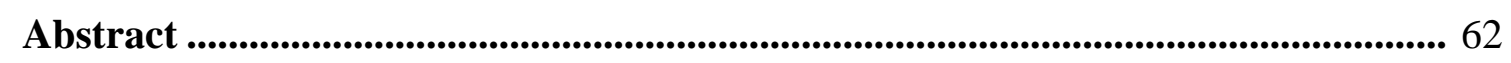

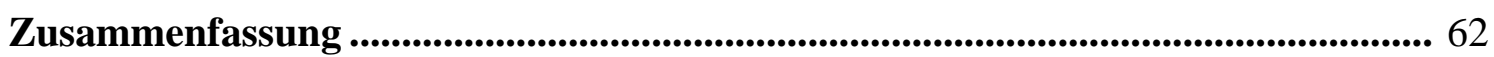

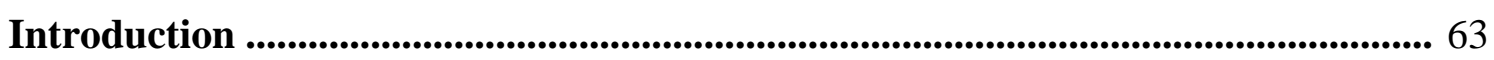

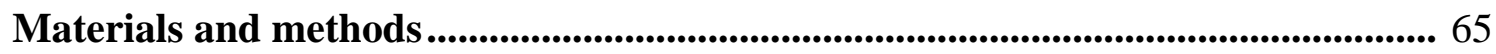

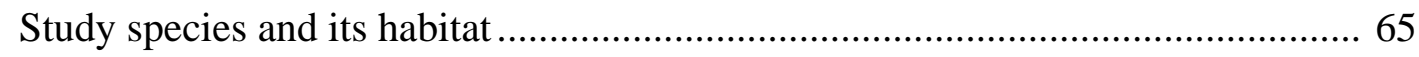

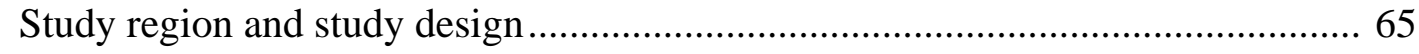

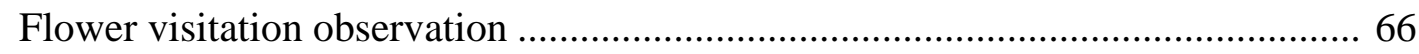

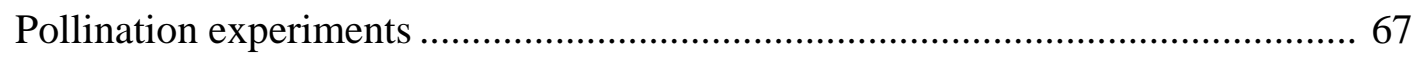

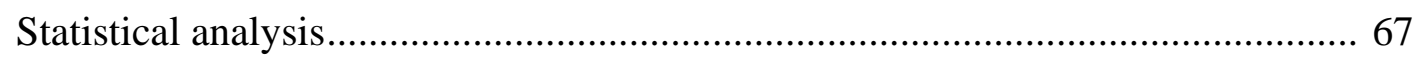

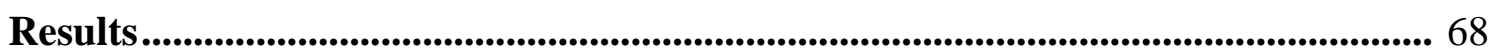

Effects of patch size, habitat area, and landscape diversity on flower visitors ...... 68

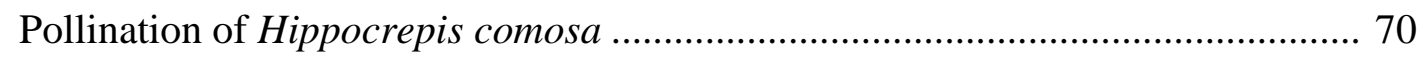

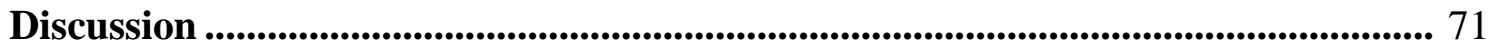

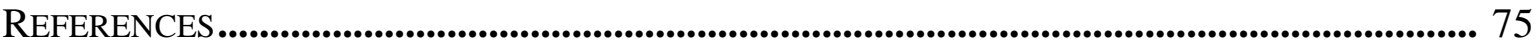

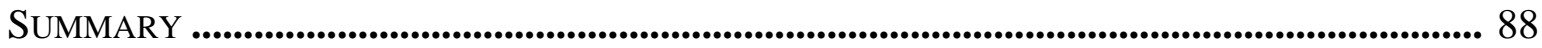

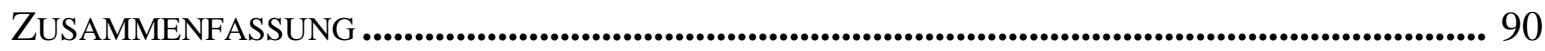

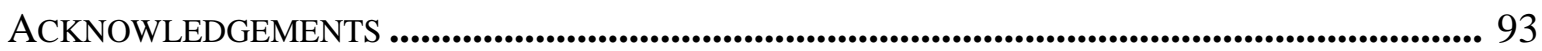

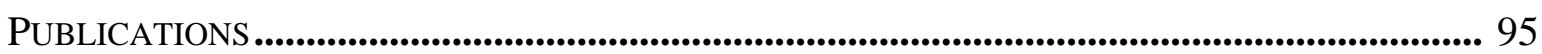

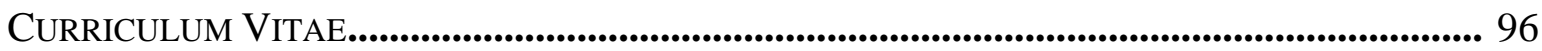




\section{CHAPTER}

1

\section{POLLINATORS IN AGRICULTURAL LANDSCAPES}

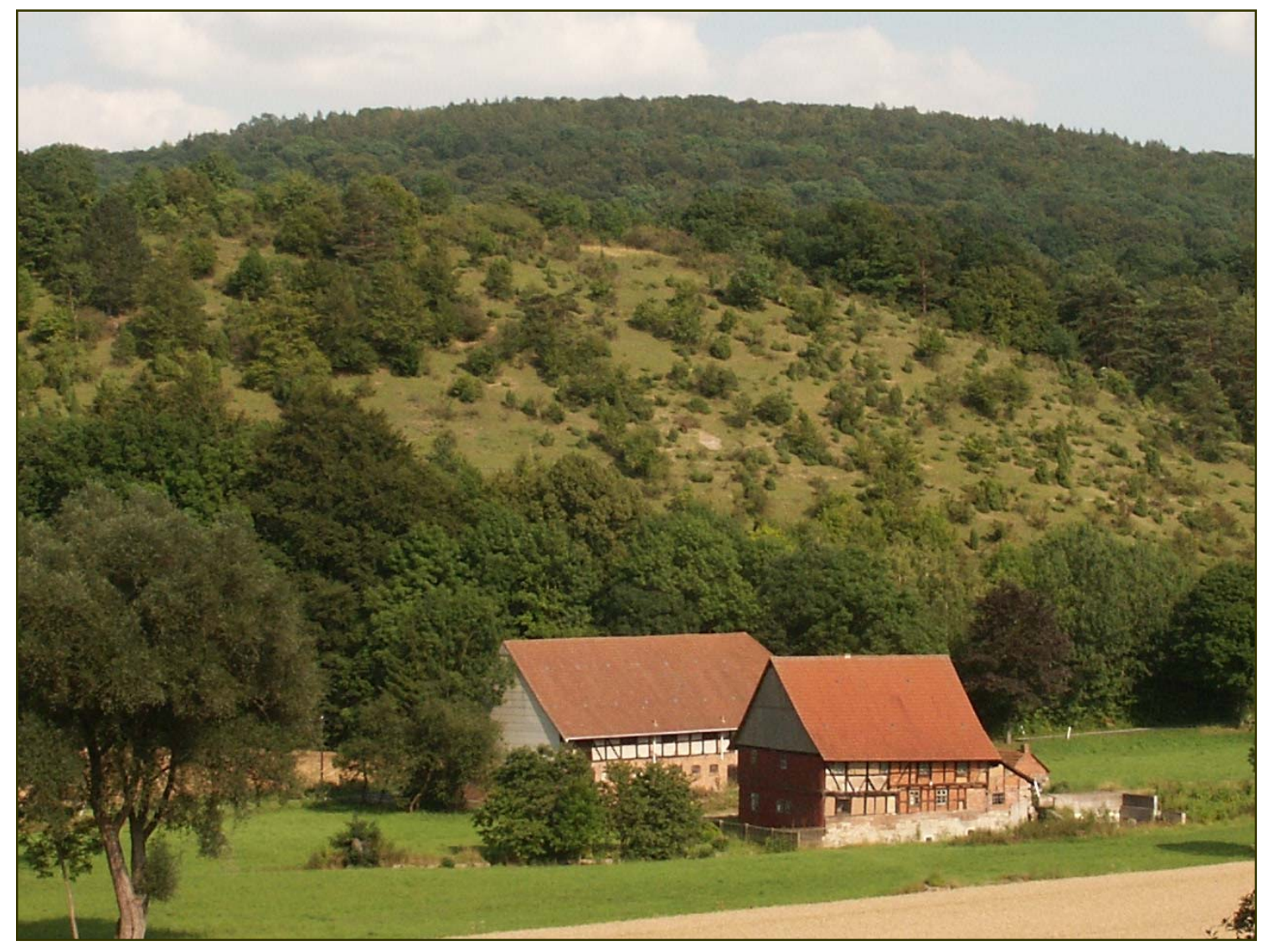




\section{Introduction}

Life is not easy for pollinators in today's agricultural landscapes. While the lowintensity agricultural practices of former times increased the biodiversity (Bignal and McCracken 1996), the intensification of farming during the last decades poses a serious threat to biodiversity in agroecosystems (Krebs 1989; Tilman et al. 2001). Flower visitors do not find sufficient pollen and nectar resources because the acreage of annual crops is increasing at the expense of flower rich perennial habitats such as grasslands, fallows, hedgerows, and field margins (Fuller 1987; Stoate et al. 2001). The few mass-flowering crops that may benefit some generalist pollinators only provide floral resources for short time intervals (Westphal et al. 2003). The use of pesticides in conventional fields reduces the diversity of weeds in arable lands (Gabriel et al. 2006). Most grasslands themselves experience a reduction in species richness and abundance of flowers because they are cultivated for early and successive harvesting with fertilizer input, reseeding, and early cutting for silage (Hopkins and Wilkins 2006).

Semi-natural habitats such as calcareous grasslands may contribute to the preservation of pollinator diversity in agroecosystems (Duelli and Obrist 2003) because they offer a rich supply of floral resources from early spring to late fall and further provide diverse microhabitats for nesting and larval development. Calcareous grasslands are therefore considered to be one of the most species-rich habitats in central Europe (WallisDeVries et al. 2002). However, they are often abandoned and left for succession since traditional land use practices such as sheep-herding have become uneconomical (Poschlod and WallisDeVries 2002). As a consequence, the total area of calcareous grasslands has decreased considerably, leaving only few remnants of small and isolated fragments in the agricultural landscape.

Fragmentation has been shown to adversely affect biodiversity in general (Fahrig 2003) and decreasing area of calcareous grassland fragments has been observed to reduce species richness of butterflies (Krauss et al. 2003). Especially species on higher trophic levels and those with poor dispersal abilities, e.g., are sensitive to the effects of fragmentation (Tscharntke et al. 2002). Thus, habitat fragmentation may not affect all species groups in the same way.

Highly mobile species, like pollinators with large foraging ranges (Walther-Hellwig and Frankl 2000; Westphal et al. 2006), are less spatially constricted to habitat fragments, but instead may also utilize the surrounding landscape matrix, at least temporarily. As opposed to monotonous agricultural areas, a diverse landscape offers additional floral resources for 
flower visitors in orchard meadows, flowering strips, gardens, and extensively used grasslands. Structural elements such as hedgerows, rocks, and forest edges provide nesting habitats or nesting materials for bees (Westrich 1989) whereas woodlands and annual crops may serve as larval habitats for many hoverfly species (Speight 2006). Hence, in addition to habitat factors, the landscape context around focal semi-natural habitats has to be considered when analysing pollinator communities (Tscharntke et al. 2005).

The detrimental effect of fragmentation and landscape homogeneity on pollinator communities potentially threatens plant-pollinator interactions on semi-natural habitats (Rathcke and Jules 1993; Kearns et al. 1998). Because of the reduction in suitable habitat and the loss of pollinators, small and sparse plant populations of insect-pollinated species may fail to attract sufficient numbers of pollinators, experience decreased visitation rates and reduced fecundity (Jennersten and Nilsson 1993; Lennartsson 2002). Pollinator limitation may be especially detrimental to self-incompatible, out-crossing plant species which obligately depend on pollinators for sexual reproduction (Aguilar et al. 2006).

\section{Study region and study sites}

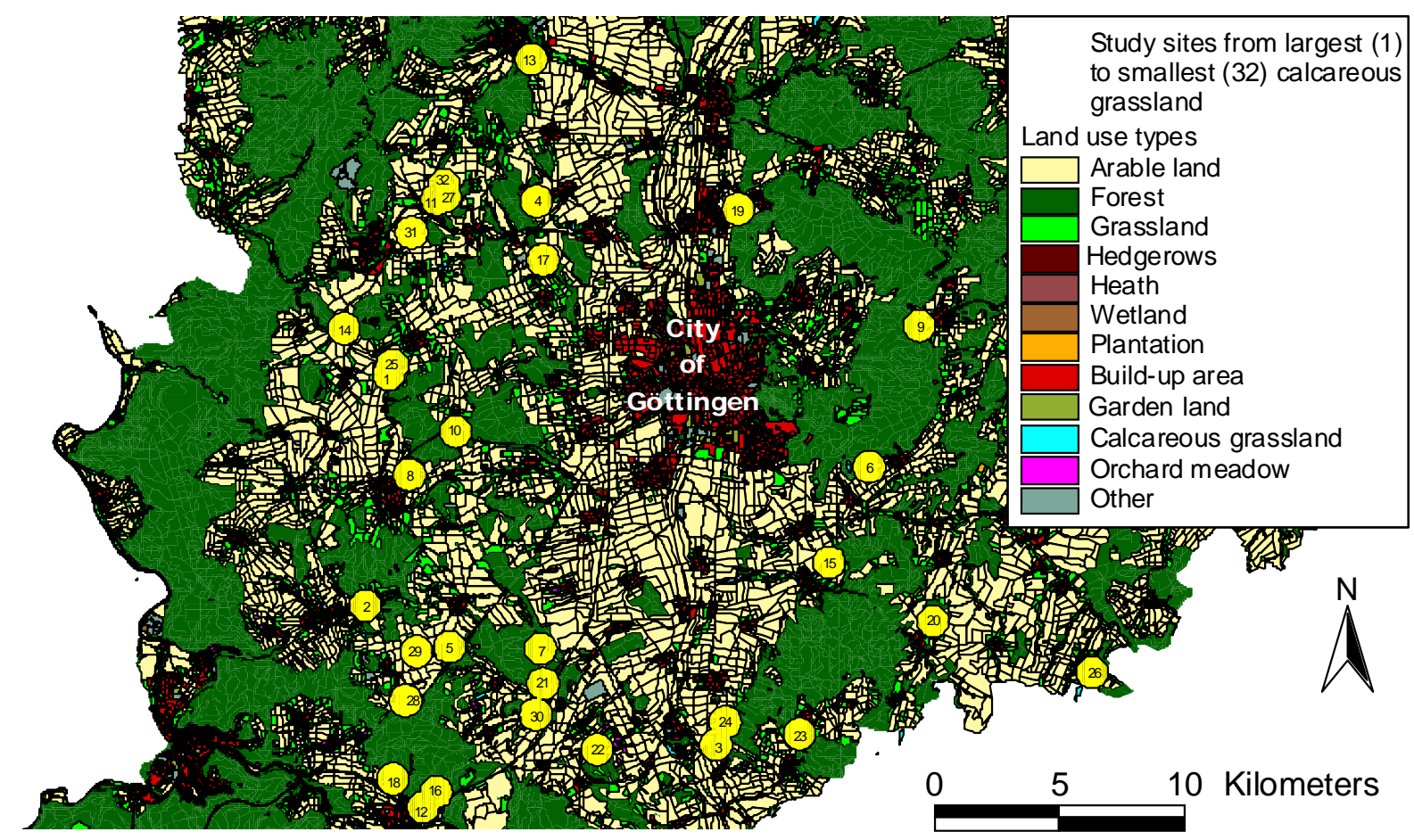

Figure 1. Location of the 32 calcareous grassland study sites around the city of Göttingen in Southern Lower Saxony, Germany 
The study region around the city of Göttingen in southern Lower Saxony, Germany, is characterized by intensively managed agricultural areas and patchily distributed fragments of semi-natural habitats. Even though the study region includes a total of 285 calcareous grassland fragments, they only cover about $0.3 \%$ of the area. For this study, 32 calcareous grasslands were selected (Fig. 1). Calcareous grasslands occur on nutrient-poor, shallow soils of calcareous rock on south or south-west facing slopes and have sharp boundaries to their surrounding matrix. They are extensively managed by sheep- or goat-herding, extensive mowing, or annual removal of woody shrubs to prevent succession. Calcareous grasslands belong to the phytosociological association Gentiano-Koelerietum and contain an exceptionally species-rich flora with xero- and thermophilic plants (Ellenberg 1996).

The selected calcareous grasslands constitute two independent gradients of habitat area and degree of isolation (Fig. 2). The study sites ranged in size from 314 to $51,395 \mathrm{~m}^{2}$. The isolation values were calculated using Hanski’s connectivity index (Hanski et al. 2000) taking into account all calcareous grasslands within a radius of $8 \mathrm{~km}$ around each study site and varied between 2,100 and 86,000 with large values indicating a low level of isolation.
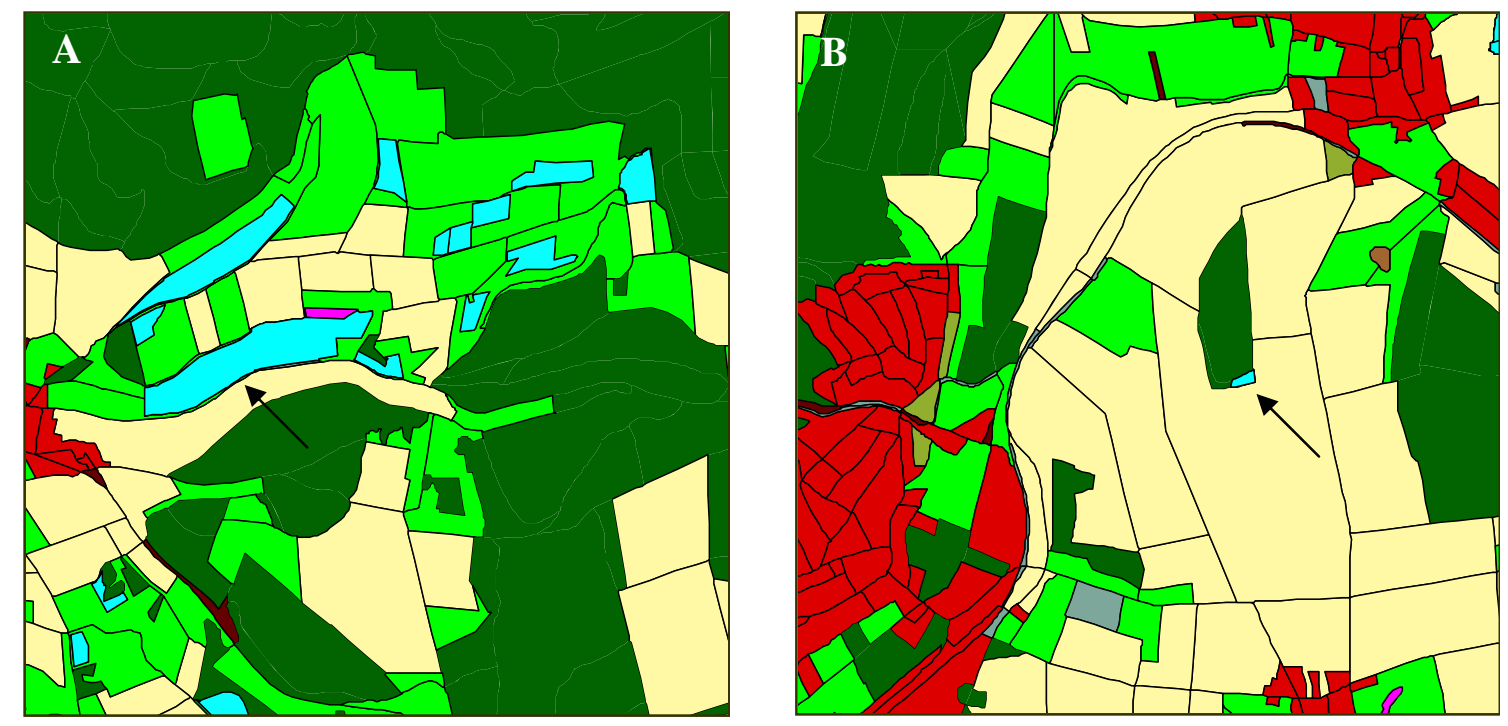

Figure 2. (A) A large, well connected and (B) a small and strongly isolated calcareous grassland in an agricultural landscape (legend s. Fig. 1). 
The selected study sites lay within landscapes of differing complexity (Fig. 3). The percentage land cover of eleven land-use types (arable land, forest, grassland, built-up area, garden land, hedgerows, calcareous grasslands, orchard meadows, fen, plantations, and other habitats) was measured at each of twelve different spatial scales ranging from 250 to $3000 \mathrm{~m}$ radius around the centre of the calcareous grassland (Fig. 4). Landscape diversity was calculated for each of the twelve spatial scales using the Shannon-Wiener index (Krebs 1989).
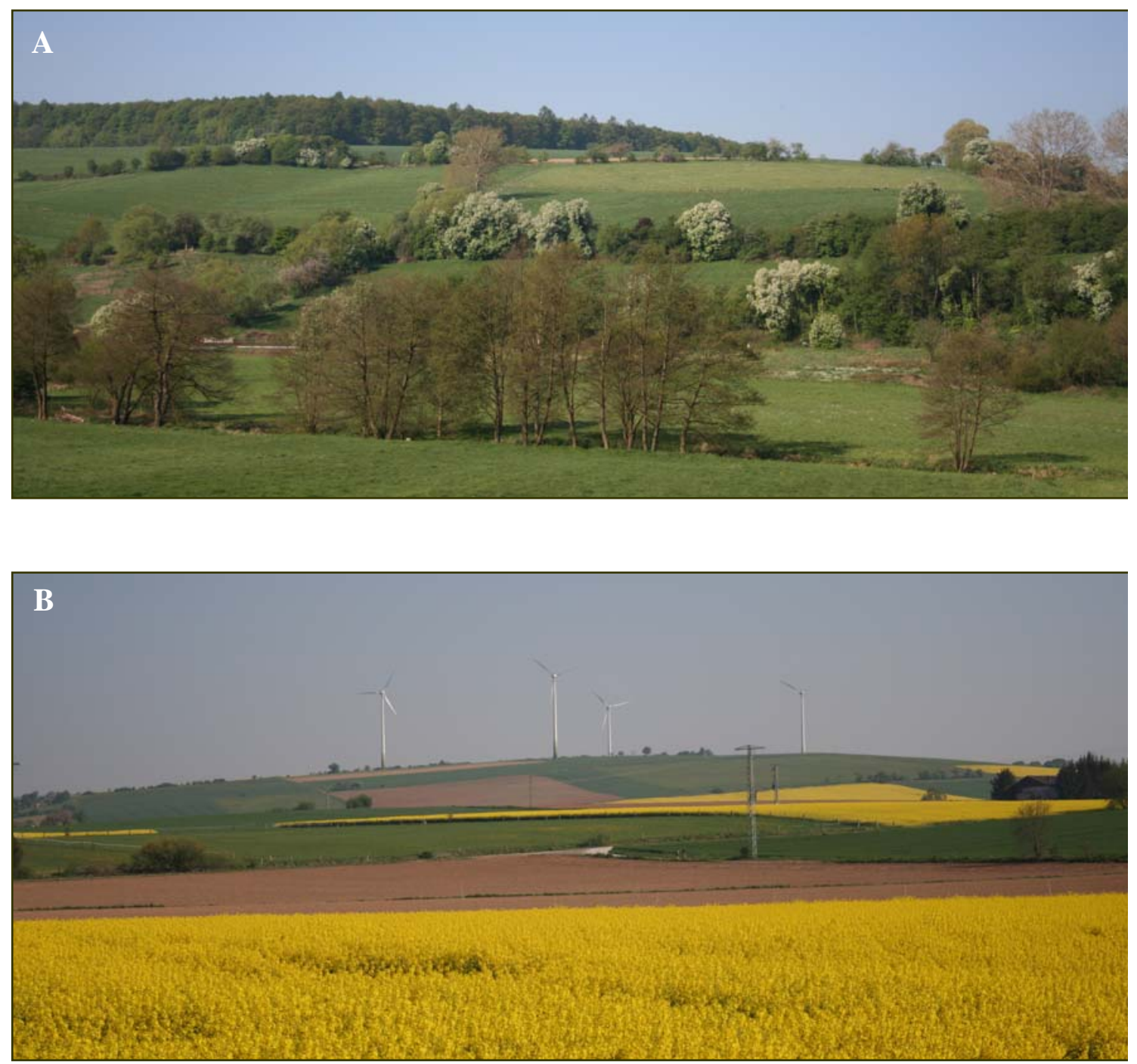

Figure 3. (A) A complex landscape with a high percentage of non-crop area (grasslands, hedges, woodlands) and (B) a structurally simple landscape with a high percentage of arable land, both north-west of Göttingen. 

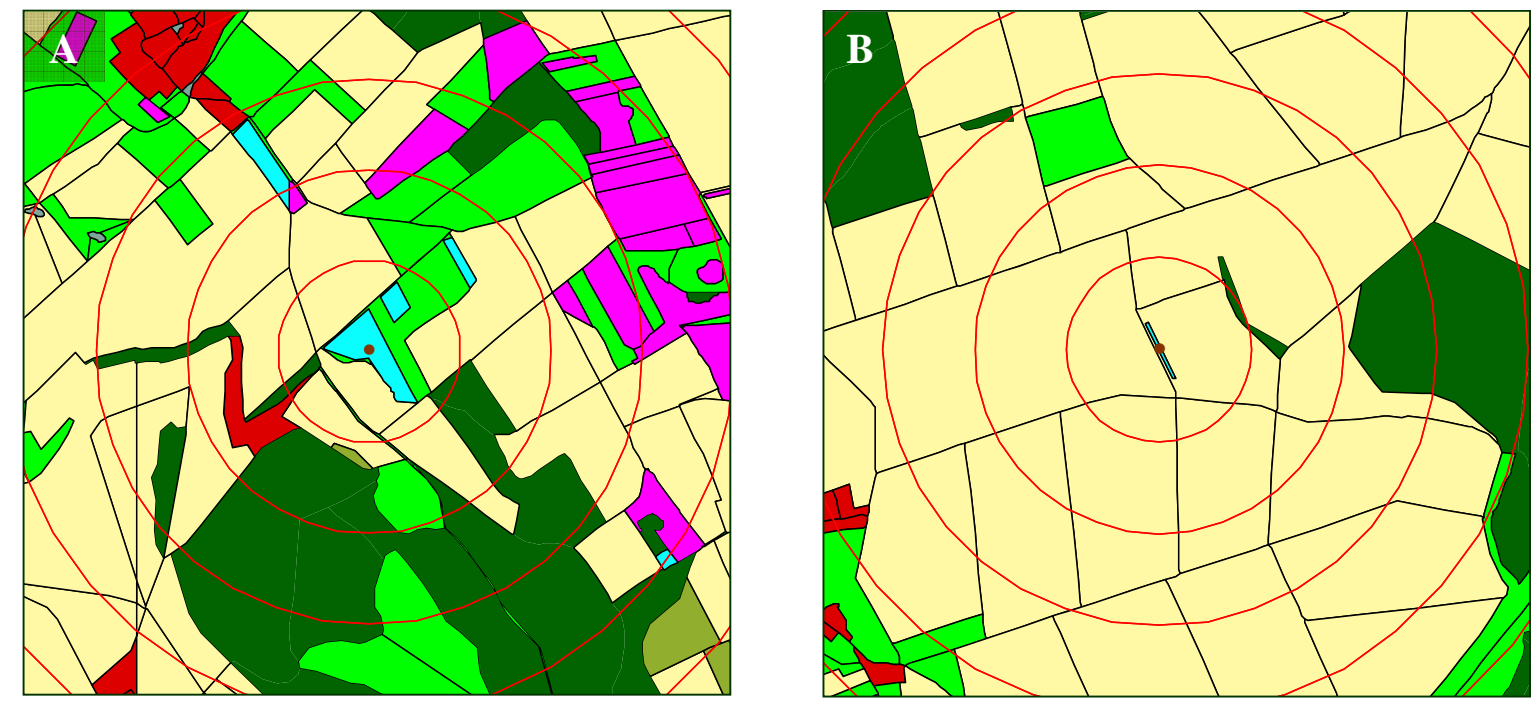

Figure 4. Landscape factors were determined in complex (A) and structurally simple (B) landscapes within each of the red circles indicating radii of 250,500, $750 \mathrm{~m}$ etc. around the focal calcareous grasslands.

\section{Research objectives}

In the following studies, the effects of fragmentation and differing landscape complexity on pollinator communities of bees (chapter 2) and hoverflies (chapter 3) are analysed and plant-pollinator interactions and reproductive success of two self incompatible grassland species, i.e. Primula veris (chapter 4) and Hippocrepis comosa (chapter 5), are examined.

\section{Chapter outline}

Importance of life history traits for pollinator loss in fragmented calcareous grasslands (Chapter 2)

This chapter analyses bee communities in 32 calcareous grasslands in an agricultural landscape around the city of Göttingen differing in size, connectivity, floral cover, and landscape context. Bee species richness was found to increase with increasing habitat size whereas density of bees was enhanced by higher floral resource availability. Increasing diversity of the surrounding landscape matrix positively influenced species richness and density of bees on calcareous grasslands at spatial scales up to $750 \mathrm{~m}$. Chapter two further examines the differences in species' responses in relation to life history traits such as dispersal ability, trophic rank and breeding strategy. Small bees with poor dispersal abilities and solitary bees were more affected by the loss of habitat area than large bees with good 
dispersal abilities, social or cuckoo (cleptoparasitic) bees. Social bees showed stronger reliance on resource availability than solitary bees. The results of chapter 2 stress the importance of considering different ecological traits of bee species for a better understanding of the effects of fragmentation.

Contrasting responses of diversity and density of hoverflies (Diptera: Syrphidae) to agricultural land use change (Chapter 3)

Chapter 3 investigates the effects of landscape context, habitat area, and resource availability on hoverfly richness and density in fragmented remnants of calcareous grasslands. Significant species-area relationships for hoverflies were observed, but no abundance-area relationships, i.e. with increasing area of calcareous grasslands species richness increased while density remained the same in all fragment sizes. Whereas hoverfly species richness was positively influenced by species richness of flowering plants, hoverfly density responded to increased floral cover. A diverse landscape positively affected the number of hoverfly species but negatively influenced the number of hoverfly individuals. The negative effect of landscape diversity on density can be explained by the different larval habitat requirements of hoverflies. A structurally poor landscape has a large proportion of annual crops that is the preferred larval habitat of a few, but dominant hoverfly species. Hence, this chapter emphasises that both, adult and larval habitat requirements, need to be considered in analysing pollinator communities.

Linking flower visitation, seed set, and seed predation of Primula veris at multiple spatial scales (Chapter 4)

This chapter examines pollination, reproductive success, and seed predation of Primula veris, a self-incompatible, declining grassland species. Mutualistic and antagonistic plant-insect interactions were analysed in differently sized patches of $P$. veris populations, in calcareous grassland fragments of differing area that were surrounded by agricultural landscapes of differing complexity. Pollination limitation was found in patches smaller than $1 \mathrm{~m}^{2}$ where supplementally hand-pollinated flowers produced more seeds per fruit than untreated flowers. The lack of pollination limitation in large patches corresponds to the elevated pollinator abundance and seed set found with increasing patch size. Pollinator abundance was further positively influenced by increased area of calcareous grassland fragments and by enhanced landscape diversity around the fragments. Seed predation by tortricid moths was most profound in large calcareous grassland fragments. This chapter illustrates that mutualistic and antagonistic relationships of pollinators and seed predators 
with $P$. veris responded to variables at different spatial scales and therefore advocates the consideration of multiple spatial scales when analysing fecundity of rare plant species.

Patch and landscape effects on pollinator diversity and seed set of Hippocrepis comosa in an agricultural landscape (Chapter 5)

Chapter 5 investigates the pollination and reproductive success of the obligately outcrossing, declining perennial herb Hippocrepis comosa. Plant-pollinator interactions were analysed in small, medium and large plant patches in differently sized calcareous grassland fragments surrounded by landscape matrices of differing diversity. Hippocrepis comosa was found to be pollination limited because supplementally hand-pollinated flowers produced more seeds per fruit than untreated flowers and because seed set was strongly reduced by decreased visitation rates. Flower visitors of $H$. comosa were most abundant in large patches demonstrating the importance of sufficiently large patches of plant species with ample rewards for pollinators in order to maintain intact plant-pollinator interactions. Because pollinator abundance was further enhanced by increased matrix heterogeneity, this chapter further emphasises the necessity of preserving a diverse agricultural landscape around the plant's habitats.

\section{Conclusions}

The different studies demonstrate that size matters: Species richness of bee and hoverfly pollinators increased with increasing area of calcareous grassland habitat illustrating that pollinator diversity is greatly dependent on the availability of semi-natural habitats such as calcareous grasslands. The abundance of flower visitors and consequently the reproductive success of Primula veris and Hippocrepis comosa were elevated in large plant patches, further demonstrating the necessity of adequate floral resources. Hence, conservation efforts need to include extensive management in semi-natural habitats such as the maintenance of calcareous grasslands by sheep-herders, land managers and environmental organisations whose work prevents calcareous grasslands from succession to scrubland and forest. Management practices should especially aim at enhancing floral availability on these grasslands providing ample rewards and supporting stable populations of pollinators.

Furthermore, a common result of all studies was a positive effect of landscape diversity on pollinators and consequently on the seed set of rare plants. Therefore, not only semi-natural areas need to be conserved, but also a complex landscape, consisting of 
extensively managed grasslands, hedgerows, orchard meadows, woodlands, and arable land, surrounding these habitats.

The effects that patch size, area of semi-natural habitat, and landscape diversity impose on pollinators and the reproductive success of rare plants demonstrate the necessity to apply multiple spatial scales in plant-pollinator analyses. The effects of habitat area and landscape complexity on different groups of bees and hoverflies further stress the importance to consider different species traits, i.e. dispersal abilities, trophic rank, breeding strategy, or different developmental stages in order to fully understand plant-pollinator interactions in agricultural landscapes. 
CHAPTER

2

IMPORTANCE OF LIFE HISTORY TRAITS FOR POLLINATOR LOSS

IN FRAGMENTED CALCAREOUS GRASSLANDS

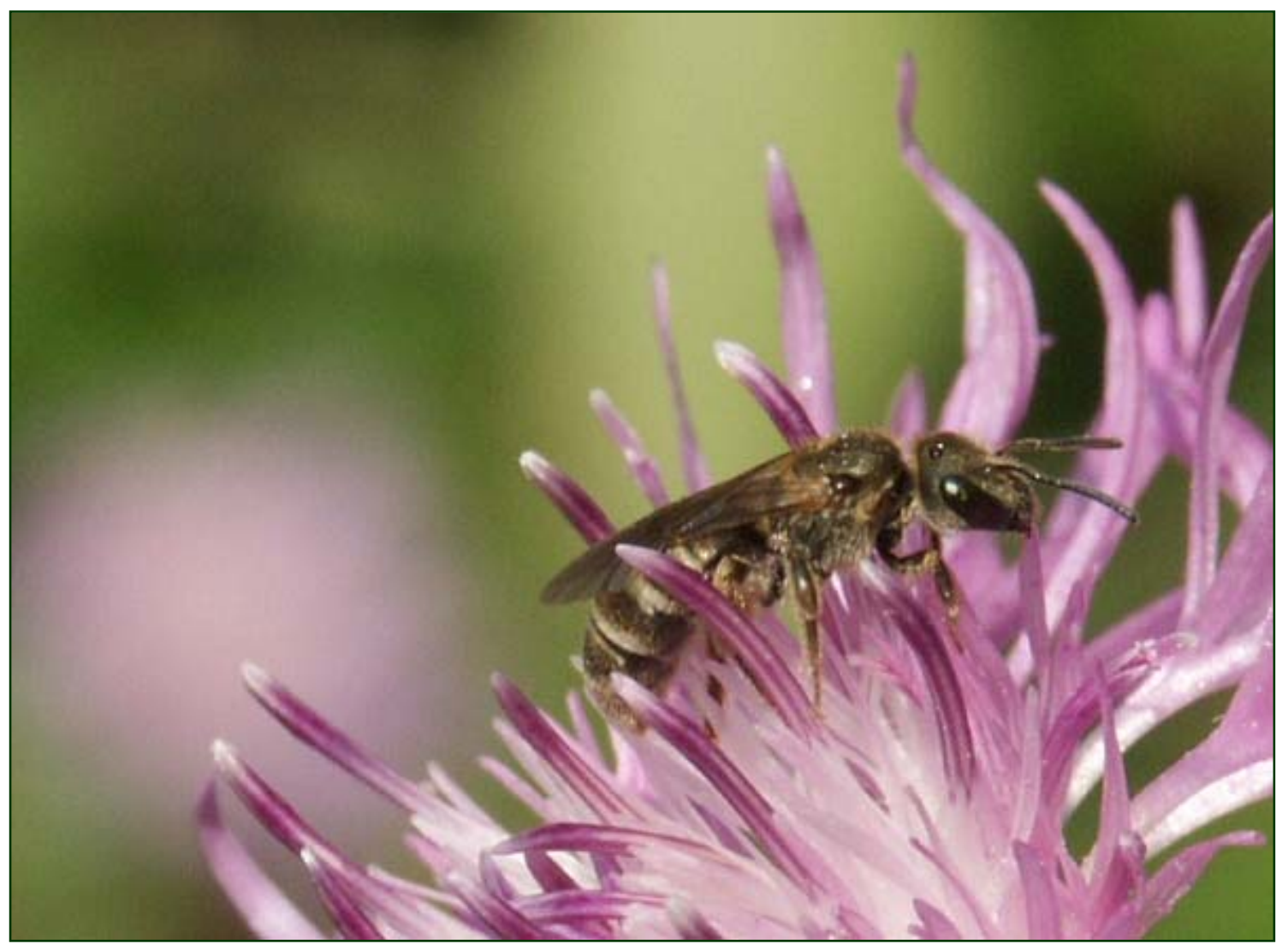




\section{Abstract}

Bees are under increasing threat because of the degradation and fragmentation of their habitats. In order to understand the factors that drive the loss of wild bees, fragmentation studies need to consider not only the size and the degree of isolation but also the quality of habitat patches and the surrounding landscape matrix. Moreover, differences in species responses in relation to life history traits such as dispersal ability, trophic rank or sociality need to be analysed. Here, we assessed bee communities in 32 calcareous grasslands around the city of Göttingen in Germany differing in size, connectivity, resource availability, and landscape context. Using transect walks, we recorded 4707 bees comprising 110 species. Richness of bee species increased with habitat size whereas density of bees was enhanced by resource availability. Increasing complexity of the surrounding landscape positively influenced species richness and density of bees on calcareous grasslands at scales up to $750 \mathrm{~m}$. Small, solitary bees were more affected by habitat area loss than large, social or cuckoo bees. Social bees showed stronger reliance on resource availability than solitary bees. We conclude that conservation of pollinator diversity in agricultural landscapes could be secured by preserving semi-natural habitats such as calcareous grasslands, enhancing their local resource availability and increasing the heterogeneity of the surrounding landscape matrix.

Key words: habitat fragmentation; landscape structure; species-area relationships; body size; social bees and solitary bees

\section{Introduction}

Bees are the most important group of pollinators in many parts of the world (LaSalle and Gauld 1993) ensuring the pollination of wild plants (Burd 1994) and agricultural crops (Klein et al. 2007). However, there is growing evidence for an ongoing decline of bees within the last decades (Westrich 1989a; Buchmann and Nabhan 1997; Biesmeijer et al. 2006), with negative consequences for pollination as one of the free ecosystem services provided by nature (Kearns et al. 1998). Therefore, it is important to determine the causes of pollinator declines in order to prevent further loss of pollinators and pollination services.

One of the most detrimental factors affecting pollinator communities is the overall loss of suitable habitat and the resulting fragmentation into smaller and more isolated habitat patches (Tscharntke and Brandl 2004). According to the theory of island biogeography, populations on these small, isolated fragments suffer from increased extinction and decreased 
immigration rates compared to large, connected fragments (MacArthur and Wilson 1967). As a consequence, species richness is higher on large, well connected habitat patches compared to small, isolated fragments. Apart from an area per se effect of habitat loss, species-area relationships may also be caused by an increase in habitat diversity with increasing patch size (Ricklefs and Lovette 1999). Heterogeneous fragments with diverse structure and vegetation offer more different resources and can therefore support a larger number of animal species (Rosenzweig 1995).

Necessary resources for solitary bees include sufficient nectar and pollen, vacant rodent burrows or suitable bare ground for below-ground nesting bees, pithy or hollow plant stems, wall or tree cavities for above-ground nesting bees, and nesting material like leaves, petals, plant hairs, resin, clay or small stones (Westrich 1989a). In agricultural landscapes of the $21^{\text {st }}$ century, bees find these diverse resources on calcareous grasslands, a semi-natural grassland type that is one of the most species-rich habitats in central Europe (WallisDeVries et al. 2002). Calcareous grasslands developed centuries ago by traditional land-use practices (Poschlod and WallisDeVries 2002). During the last decades, as land use practices like sheepand goat-herding became uneconomical, many calcareous grasslands were replaced by intensively managed agricultural land-use types or abandoned to natural succession (Poschlod and WallisDeVries 2002). The loss of calcareous grassland area leads to an increased threat to its diverse flora and fauna (e.g. Steffan-Dewenter and Tscharntke 2000; Krauss et al. 2003; Matthies et al. 2004), with negative effects on the plant-pollinator community (Rathcke and Jules 1993; Kearns et al. 1998). Some studies have reported reduced bee species richness in smaller and more isolated habitat patches (e.g. Powell and Powell 1987; Aizen and Feinsinger 1994). These results, however, have been criticised, because of a coarse taxonomic resolution that did not allow for ecological interpretations (Cane 2001). A better understanding of the effects of habitat loss can be reached by considering different ecological traits of bee species (Cane et al. 2006). Species at higher trophic levels and species with poor dispersal abilities, for example, are predicted to be more sensitive to habitat loss (Holt et al. 1999; Ewers and Didham 2006), but case studies demonstrating these predictions are rare.

In most fragmentation studies habitat fragments are considered as islands surrounded by a hostile matrix. For bees, however, remaining calcareous grassland patches are surrounded by a matrix of varying permeability (Ricketts 2001). Whereas a homogenous landscape composed of only e.g. winter wheat fields is likely to inhibit dispersal, a more diverse landscape providing pastures and other grasslands may be relatively permeable for bees. Landscape diversity may therefore indirectly alter the effects of habitat loss on bees. 
Further, landscape diversity may influence pollinator communities directly. Bees might profit from a complex matrix with orchard meadows, hedgerows, garden land and flowering crops because their foraging ranges are often larger than the extent of single habitat patches (Walther-Hellwig and Frankl 2000; Gathmann and Tscharntke 2002) and they can therefore utilise the additional, but spatially separated nesting and foraging habitats that a diverse landscape offers. Thus, in addition to local factors, there is a need to consider the landscape context around focal semi-natural habitats to deepen the understanding of factors determining the species richness and abundance of pollinator communities (Tscharntke and Brandl 2004). In analysing effects of habitat loss on diversity, one has to further take into account the quality of a habitat in terms of resource availability and diversity (Rosenzweig 1995). Particularly social species are expected to depend on the availability of large amounts of floral resources required to provision their numerous offspring.

In our study, we examine the effects of fragmentation of calcareous grassland on species richness and density of bees (Hymenoptera: Apiformes). We hypothesise that pollinator species richness and density decreases with decreasing habitat area and connectivity. We further expect that susceptibility to habitat fragmentation depends on the different life history traits of bee species. Small bees with poor dispersal abilities and species at higher trophic levels such as cleptoparasitic bees should be more sensitive to loss of calcareous grassland. In addition, we assume that increasing resource availability within patches and increasing habitat diversity in the landscape matrix benefit pollinator communities in semi-natural habitat fragments.

\section{Materials and methods}

Study region

The study was conducted in the Leine-Bergland around the city of Göttingen in Lower Saxony, Germany, in 2004. The study region is characterized by intensively managed agricultural areas and patchily distributed fragments of semi-natural habitats. Even though our study region includes a total of 285 calcareous grassland fragments, they only cover about $0.3 \%$ of the area in the study region. Calcareous grasslands occur on shallow, lime-rich soils, usually on south or south-west facing slopes and have sharp boundaries to their surrounding matrix. They belong to the plant association Gentiano-Koelerietum and are extensively managed by sheep- or goat-herding, extensive mowing, or annual removal of woody shrubs. We selected 32 calcareous grasslands around the city of Göttingen that covered the entire gradient of habitat area, connectivity, and landscape context in the study area. 
Habitat and landscape characteristics

Quantification of habitat area, connectivity, and landscape diversity is based on Krauss et al. (2003). The area of the 32 grassland fragments was measured in 2000 with a differential GPS GEOmeter 12L (GEOsat GmbH, Wuppertal, Germany) and ranged from $314-51,395 \mathrm{~m}^{2}$.

Habitat connectivity ( $C$, inverse of isolation) measurements took into account all calcareous grasslands within a radius of $8 \mathrm{~km}$ around each study site $(j)$ and were calculated using Hanski's connectivity index (Hanski et al. 2000):

$$
C_{j}=\sum_{j \neq k} \exp \left(-a d_{j k}\right) A_{k}^{b}
$$

where $A$ is the area $\left[\mathrm{m}^{2}\right]$ and $d$ the distance $[\mathrm{km}]$ from each neighbouring grassland $(k)$. The parameter $a$ is a species-specific parameter describing the dispersal ability of a species and the parameter $b$ the scaling of immigration. As we applied this index not to a single species but to an entire community, both parameters were set equal to one in this analysis. The connectivity values varied between 2,100 and 86,000 with large values signifying high connectivity. We also measured the distance to the nearest neighbouring calcareous grassland. Distance values ranged from 55 to $1894 \mathrm{~m}$.

The study region covers an area of about $1,944 \mathrm{~km}^{2}$. Land cover was separated into eleven land-use types: arable land (42.15\%), forest (36.80\%), grassland (12.14\%), built-up area $(6.24 \%)$, other habitats $(1.48 \%)$, garden land $(0.31 \%)$, hedgerows $(0.30 \%)$, calcareous grasslands $(0.26 \%)$, orchard meadows $(0.20 \%)$, fen $(0.05 \%)$, and plantations $(0.06 \%)$ (ATKIS-DLM 25/1 Landesvermessung und Geobasisinformationen Niedersachsen 19911996, Hannover Germany; ATKIS-DLM 25/2 Hessisches Landesvermessungsamt 1996, Kassel, Germany). Using Geographic Information Systems (ArcView GIS 3.2, ESRI Geoinformatik, Hannover, Germany) the percentage land cover of different habitat types was measured and landscape diversity $\left(H^{\prime}\right)$ was calculated at each of twelve different spatial scales ranging from 250 to $3000 \mathrm{~m}$ radius around the centre of the calcareous grassland using the Shannon-Wiener index (Krebs 1989). Because landscape diversity of the twelve different landscape scales correlated significantly with each other, we used only the most significant landscape scale $(250 \mathrm{~m})$ for further analysis.

Resource availability was quantified after each five-minute subunit of a transect walk by determining all plant species in flower and estimating their percent floral cover. Flower cover per subunit was averaged per study site and ranged from 5.0 to $20.5 \%$. Flower diversity was pooled and ranged from 24 to 56 flowering species per site. 
The two isolation indices, Hanski's connectivity index and distance to the nearest calcareous grassland, were correlated (Table 1). Since the distance also correlated with landscape diversity, we used only the connectivity index for further analysis. Habitat area was marginally correlated with landscape diversity at a $250 \mathrm{~m}$ radius and significantly correlated with resource availability, i.e. diversity and percent cover of flowering plants (Table 1). Because the correlation between habitat area and flower diversity was strong $(r>0.5)$, we excluded flower diversity from further analysis using only flower cover as a measure of resource availability.

Table 1. Pearson correlation coefficients $(r)$ for the independent variables of the 32 calcareous grasslands. Habitat area and connectivity were $\log 10$-transformed.

\begin{tabular}{|c|c|c|c|c|c|}
\hline & $\begin{array}{c}\text { Habitat area } \\
\qquad\left[\mathrm{m}^{2}\right]\end{array}$ & $\begin{array}{c}\text { Habitat } \\
\text { connectivity } \\
\text { index }\end{array}$ & $\begin{array}{l}\text { Distance to } \\
\text { next } \\
\text { grassland }[\mathrm{m}]\end{array}$ & $\begin{array}{c}\text { Landscape } \\
\text { diversity } \\
\text { (radius: } 250 \mathrm{~m} \text { ) }\end{array}$ & $\begin{array}{c}\text { Cover of } \\
\text { plant species } \\
\text { in flower }\end{array}$ \\
\hline Habitat connectivity index & -0.02 n.s. & & & & \\
\hline Distance to next grassland [m] & -0.09 n.s. & $-0.49 * *$ & & & \\
\hline Landscape diversity (radius: $250 \mathrm{~m}$ ) & $0.32(*)$ & 0.01 n.s. & $-0.35 *$ & & \\
\hline Cover of plant species in flower & $0.38 *$ & -0.13 n.s. & -0.03 n.s. & 0.16 n.s. & \\
\hline Number of species in flower & $0.54 * * *$ & -0.17 n.s. & -0.13 n.s. & 0.23 n.s. & 0.18 n.s. \\
\hline
\end{tabular}

Significance levels: $* * * P<0.001 ; * * P<0.01 ; * P<0.05$; $\left(^{*}\right) P<0.1$; n.s. $=$ not significant

\section{Pollinator sampling}

Bees (Hymenoptera: Apiformes) were sampled via transect walks six times from April to September 2004 on 32 calcareous grasslands. Easily distinguishable species like Apis mellifera, Bombus pascuorum, etc. were identified on the wing, other species were caught with a net and identified in the lab (Scheuchl 1996; Schmid-Egger and Scheuchl 1997; Amiet et al. 1999; Scheuchl 2000; Amiet et al. 2001; Mauss 1987). Bees were recorded within a $4 \mathrm{~m}$ corridor on sunny days with little wind. All study sites were sampled in a randomized sequence and at different times during the day (morning, noon, afternoon). To achieve adequate sample sizes, transect time varied from $20 \mathrm{~min}$ on eleven small fragments (314$\left.1,133 \mathrm{~m}^{2}\right)$ over $40 \mathrm{~min}$ on 13 medium fragments $\left(1,326-7,887 \mathrm{~m}^{2}\right)$ to $60 \mathrm{~min}$ on eight large fragments $\left(11,528-51,395 \mathrm{~m}^{2}\right)$. Counts were conducted in 5 min subunits (four subunits of 5 min duration on the small sites, eight subunits on medium and twelve subunits on large sites). Transect distance per subunit was measured to calculate bee abundance per square meter. Species numbers and abundance of all bees were pooled for each study site over the sampling period. In order to compare responses of bees to species groups in other species-area studies, 
we calculated the slope $z$ of the $\log -\log$ relationships (Rosenzweig 1995). A high value of $z$, i.e. a steeper species-area curve, indicates a higher sensitivity of a species group to area loss.

Species were assigned to groups according to their life history traits (Appendix 1): (1) body size according to the literature as a measure of dispersal ability (small bees $\leq 10 \mathrm{~mm}$; large bees > 10 mm) (Scheuchl 1996; Schmid-Egger and Scheuchl 1997; Amiet et al. 1999; Scheuchl 2000; Amiet et al. 2001; von Hagen and Aichhorn 2003) and (2) breeding strategy (social bees; solitary nest builders; cleptoparasites) (Westrich 1989b). Social bees are primitively eusocial species, including all Bombus spp. and some species of the genera Halictus and Lasioglossum. The genera Melecta, Nomada, Psithyrus and Sphecodes are cleptoparasitic bees, also called cuckoo bees. They represent a higher trophic level because their larvae feed on the brood cell provisions of their bee hosts at the expense of the host larvae. All other species are solitary bees that build their nests individually. We could not analyse bees according to their food specialisation, because there were mainly polylectic species among the sampled bees (98.1\% of bee individuals $82.7 \%$ of species). We did not include honey bees in the analyses because occurrence and densities of honey bees are largely determined by beekeepers.

\section{Statistical analyses}

The statistical analyses of the data were carried out using $\mathrm{R}$, Version 2.3.1 ( $\mathrm{R}$ Development Core Team 2006). All response variables were tested for meeting the assumptions of normality and homoscedasticity. We calculated Spearman Rank correlations, Pearson correlations and multiple regressions using type 1 sums of squares and a backward selection procedure using the step function in $\mathrm{R}$. The sequence of explanatory variables that entered the model, going from smallest to largest scale, was (1) flower cover, (2) habitat area, (3) landscape diversity (4) habitat connectivity (5) the interaction between landscape diversity and habitat area, and (6) the interaction between landscape diversity and connectivity. To analyse differential effects of the explanatory variables on different bee groups we used mixed effects models with the maximum likelihood procedure. As fixed factors we used species grouping (body size or breeding strategy nested within each patch), flower cover, habitat area, landscape diversity, connectivity, and the interactions between species groups and the patch characteristics. As the random factor in the analyses we used patch identity. Significant interactions between species groups and patch characteristics indicate significant differences in slopes of the species groups' relationship to patch characteristics.

To correct for the different sampling efforts on small, medium, and large calcareous grassland fragments, we estimated the species number we would have found if we had evenly 
sampled four subunits on each site using EstimateS, Version 7.5 (Colwell 2004). We also used the second-order Jackknife richness estimator to estimate overall species richness and calculate the percentage of sampled species in relation to total estimated species richness per habitat. To avoid effects of season-dependent species turnover, we pooled the first, second, third etc. 5 min subunits of all six transect walks per site. Small grasslands with 20 minutes transect walks have therefore four subunits, intermediate fragments with 40 min have eight and large grasslands have twelve subunits to calculate estimated species richness. Percent saturation varied between $52-80 \%$ and did not correlate significantly with habitat area $\left(\mathrm{n}=32, r_{S}=0.26, P=0.158\right)$.

\section{Results}

We recorded 4707 bee individuals representing 110 species in 21 genera (Appendix 1). The most abundant and most frequent species were Bombus lapidarius (19.2\%), Apis mellifera (16.3\%), Bombus pascuorum (9.7\%), Bombus terrestris (6.3\%), Halictus tumulorum (5.7 \%), Lasioglossum pauxillum (5.4\%), and Osmia bicolor (4.3\%).

Table 2: Multiple regression analysis of the relationship between species richness (sampled, estimated in four subunits, and estimated overall) and densities of all bees and the independent factors flower cover, habitat area, landscape diversity (radius $250 \mathrm{~m}$ around centre), habitat connectivity of the 32 calcareous grasslands, and interactions between landscape diversity and habitat area and connectivity. Habitat area and connectivity were $\log 10$-transformed. Given are $r^{2}$ of the total model and $F$ and $P$-values for significant factors.

\begin{tabular}{lllccc}
\hline & Variable in model & Effect & $F$ & $P$ & Multiple $r^{2}$ \\
\hline Sampled bee species richness & Habitat area & positive & 46.96 & $<0.001$ & 0.63 \\
& Landscape diversity & positive & 3.12 & 0.088 & \\
Estimated richness in 4 subunits & Habitat area & positive & 9.13 & 0.005 & 0.30 \\
& Landscape diversity & positive & 3.46 & 0.073 & \\
Estimated overall species richness & Habitat area & positive & 29.76 & $<0.001$ & 0.58 \\
& Landscape diversity & positive & 3.66 & 0.066 & \\
Bee abundance $\left(\right.$ per $\left.\mathrm{m}^{2}\right)$ & Habitat connectivity & negative & 4.88 & 0.036 & \multirow{2}{*}{0.26} \\
& Flowercover & positive & 6.44 & 0.017 & \\
& Landscape diversity & positive & 3.65 & 0.066 & \\
\hline
\end{tabular}

\section{Habitat area and connectivity}

A multiple regression analyses with all explanatory variables revealed that habitat area was the most important factor in determining species richness of bees (Table 2). Species numbers increased significantly with increasing size of grassland fragments (Fig. 1). The zvalue (slope of log-log regressions) was $z=0.22$. The species-area-relationship was significant for sampled species richness as well as for the estimated species richness we would have found if we had evenly sampled four subunits on each site and for overall species 
richness estimated with the second-order Jackknife richness estimator (Table 2). According to the multiple regression analysis, habitat area was not a significant factor determining bee density (Table 2).

Habitat connectivity was only significantly related to bee species richness when we analysed the second order Jackknife richness estimator, but with a negative relation (Table 2). We did not find a significant effect of connectivity on bee density.

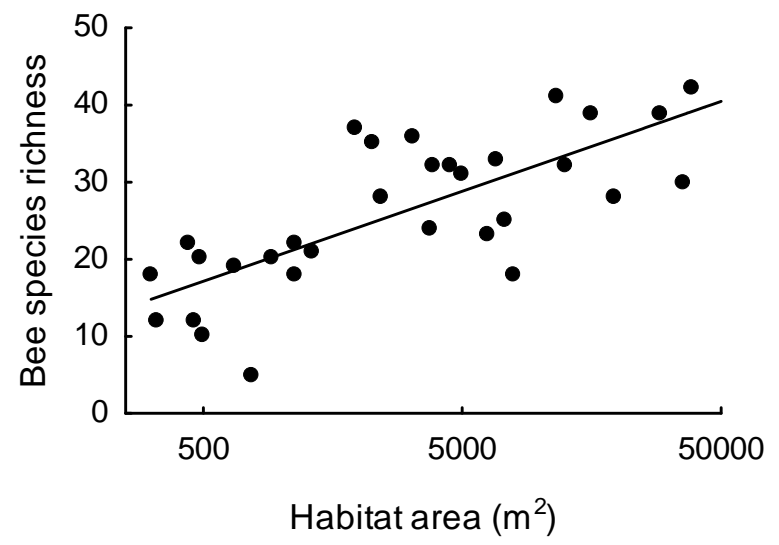

Figure 1: Relation between bee species richness and area of 32 calcareous grasslands $\left(F_{1,29}=46.96, P<0.001\right)$.

\section{Resource availability}

Flower cover was most significantly correlated to bee density. Bee abundance per $\mathrm{m}^{2}$ increased significantly with increasing percent cover of flowering plant species (Fig. 2). Flower cover was not a significant factor determining species richness.

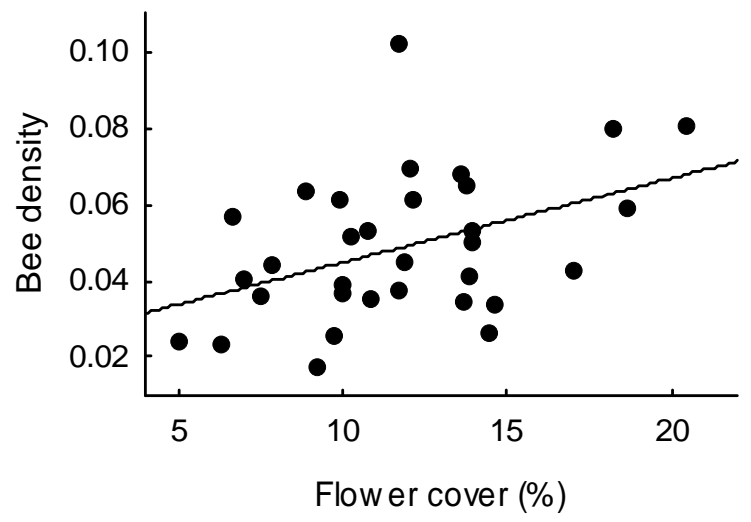

Figure 2: Relation between bee abundance per $\mathrm{m}^{2}$ and average flower cover in percent of 32 calcareous grasslands $\left(F_{1,29}=6.44, P=0.017\right)$.

\section{Effects of landscape matrix}

We analysed the effects of landscape diversity on species richness and density of bees at twelve different spatial scales (ranging from 250 to $3000 \mathrm{~m}$ radius). Landscape diversity 
had the most significant effects on species richness and density of bees at the smallest scale, i.e. at the $250 \mathrm{~m}$ radius (Fig. 3). The 500 and $750 \mathrm{~m}$ scales were still significant for density and marginally significant for species richness. The $1000 \mathrm{~m}$ scale was only marginally significant for bee density.

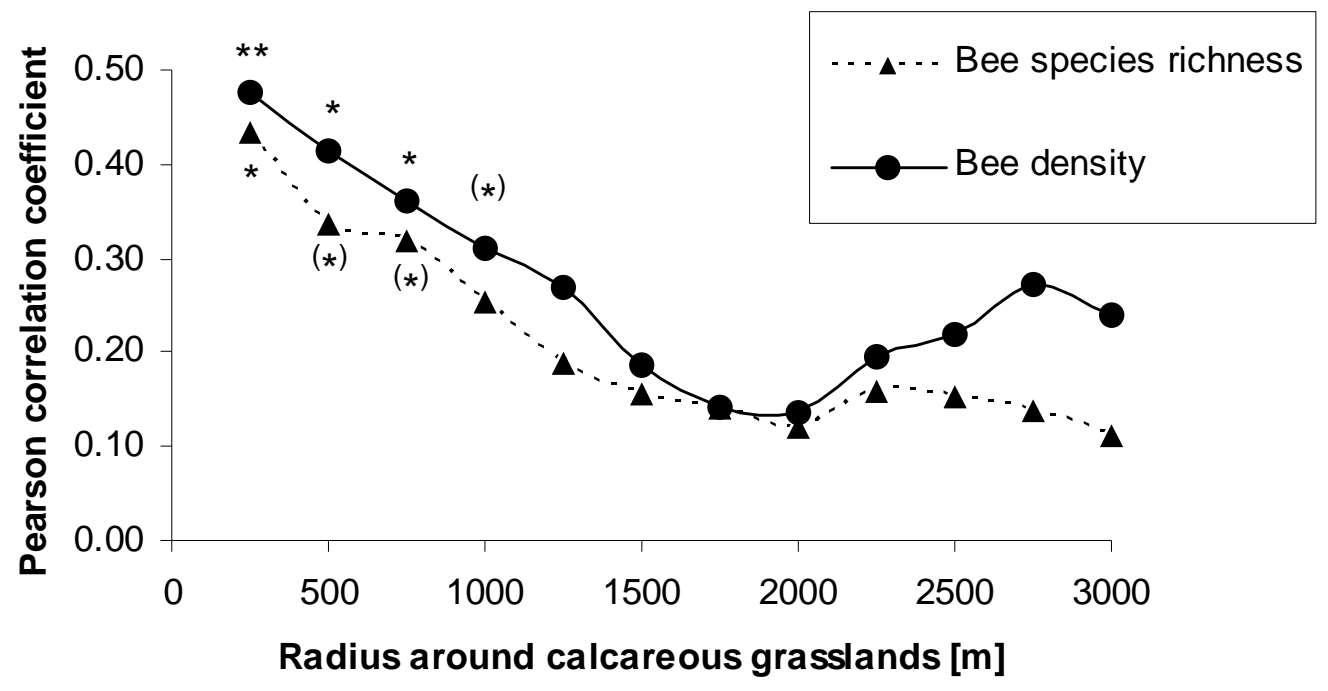

Figure 3: Pearson correlation coefficients between bee density and species richness and landscape diversity (Shannon-Wiener index) on twelve different scales ranging from 250 to $3000 \mathrm{~m}$ radius around 32 calcareous grasslands.

In the multiple regression model landscape diversity was marginally significant in determining both species richness and density of bees on calcareous grasslands (Table 2). We did not find any significant interactions between landscape diversity and habitat area or connectivity.

\section{Body size}

We compared the responses of the two different groups; bees of $10 \mathrm{~mm}$ and smaller (1843 individuals, 65 species) and bees larger than $10 \mathrm{~mm}$ (2095 individuals, 44 species) to the explanatory variables. We found that the size of the habitat fragments was the only factor that had significantly differing effects on species richness and density of small versus large bees (Table 3). Species richness (Fig. 4) as well as density increased more steeply for small than for large bees. Slopes of log-log regression lines for small bees $(z=0.32)$ and large bees $(z=0.19)$ differed significantly $(F=25.59, P<0.001)$. 
Table 3: $F$ and $P$-values of mixed effects models with body size nested within each patch, flower cover, habitat area, landscape diversity (radius $250 \mathrm{~m}$ around centre), connectivity, and the interactions between species groups and patch characteristics of the 32 calcareous grasslands as fixed factors and patch identity as the random factor. Habitat area and connectivity were log10-transformed. Significant interactions between species groups and patch characteristics indicate significant differences in slopes of species richness and densities of small versus large bees responding to patch characteristics.

\begin{tabular}{lcccc}
\hline & \multicolumn{2}{c}{ Species richness } & \multicolumn{2}{c}{ Density } \\
& $F$ & $P$ & $F$ & $P$ \\
\hline Body size & 25.59 & $<0.001$ & 4.59 & 0.041 \\
Flower cover & 8.99 & 0.006 & 5.46 & 0.027 \\
Habitat area & 37.35 & $<0.001$ & 0.43 & n.s. \\
Landscape diversity & 3.08 & 0.091 & 2.69 & n.s. \\
Habitat connectivity & 2.01 & n.s. & 0.13 & n.s. \\
Body size : Flower cover & $\mathbf{3 . 7 5}$ & $\mathbf{0 . 0 6 3}$ & $\mathbf{1 . 0 4}$ & n.s. \\
Body size : Habitat area & $\mathbf{1 3 . 7 0}$ & $<\mathbf{0 . 0 0 1}$ & $\mathbf{1 0 . 2 1}$ & $\mathbf{0 . 0 0 4}$ \\
\hline
\end{tabular}

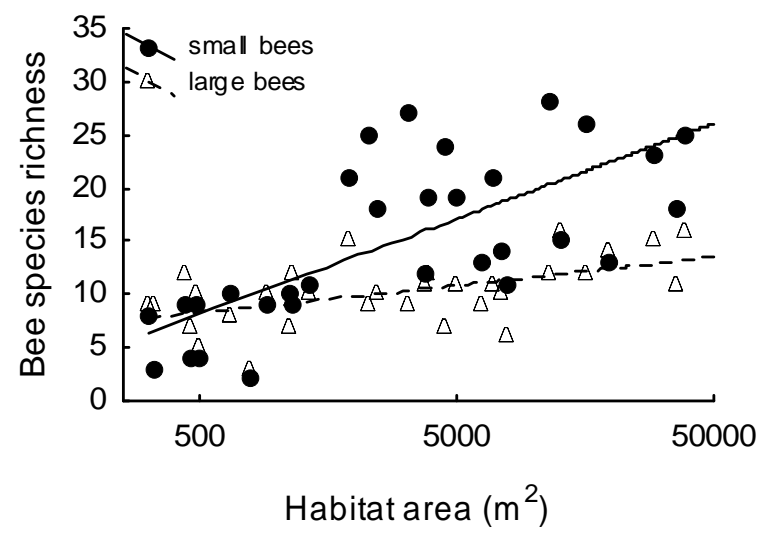

Figure 4: Relationship between species richness of small ( 65 species) and large ( 44 species) bees and area of 32 calcareous grasslands.

\section{Breeding strategies}

A multiple regression analysis comparing the responses of the three different bee groups to the explanatory variables showed that species richness of the different groups responded significantly different only to habitat area (Table 4). Solitary bee species were more sensitive to area loss than social bees or cuckoo bees (Fig. 5). Slopes of log-log regression lines for solitary $(\mathrm{z}=0.28)$ and social bees $(\mathrm{z}=0.14)$ were significantly different $(F=8.65, P=0.007)$. The $z$-value of cleptoparasites $(z=0.22)$ did not differ significantly from either solitary or social bees. Densities of the different breeding types, on the other hand, responded differently only to flower cover (Table 4); density of social bees increased more strongly with increasing flower cover than density of solitary or cuckoo bees (Fig. 6). 
Table 4: $F$ and $P$-values of mixed effects models with breeding strategy nested within each patch, flower cover, habitat area, landscape diversity (radius $250 \mathrm{~m}$ around centre), connectivity, and the interactions between species groups and patch characteristics of the 32 calcareous grasslands as fixed factors and patch identity as the random factor. Habitat area and connectivity were $\log 10$-transformed. Significant interactions between species groups and patch characteristics indicate significant differences in slopes of species richness and densities of social, solitary and cuckoo bees responding to patch characteristics.

\begin{tabular}{lcccc}
\hline & \multicolumn{2}{c}{ Species richness } & \multicolumn{2}{c}{ Density } \\
& $F$ & $P$ & $F$ & $P$ \\
\hline Breeding Strategy & 37.12 & $<0.001$ & 108.64 & $<0.001$ \\
Flower cover & 8.35 & 0.008 & 6.12 & 0.020 \\
Habitat area & 36.33 & $<0.001$ & 0.47 & n.s. \\
Landscape diversity & 3.09 & 0.090 & 2.70 & n.s. \\
Habitat connectivity & 2.15 & n.s. & 0.13 & n.s. \\
Breeding Strategy : Habitat area & $\mathbf{9 . 1 2}$ & $<\mathbf{0 . 0 0 1}$ & $\mathbf{0 . 2 6}$ & n.s. \\
Breeding Strategy : Flower cover & $\mathbf{2 . 4 8}$ & $\mathbf{0 . 0 9 4}$ & $\mathbf{7 . 4 9}$ & $\mathbf{0 . 0 0 1}$ \\
\hline
\end{tabular}

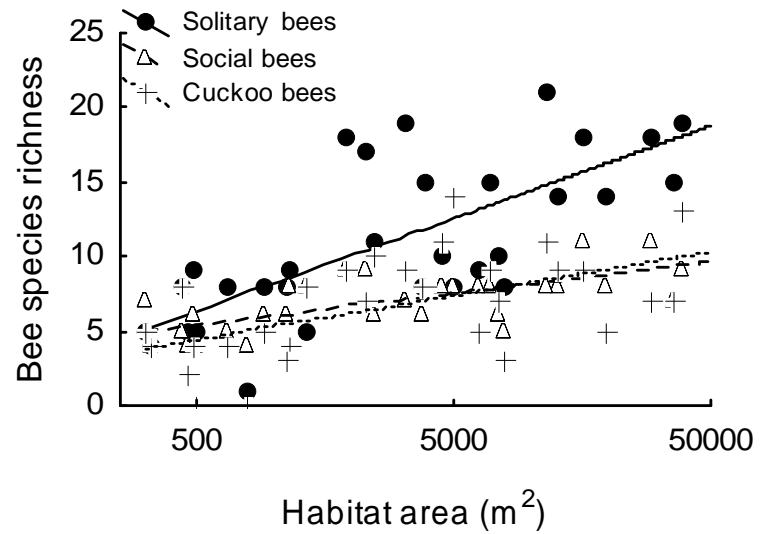

Figure 5: Relationship between species richness of solitary (61 species), social (17 species), and cuckoo (28 species) bees and area of 32 calcareous grasslands.

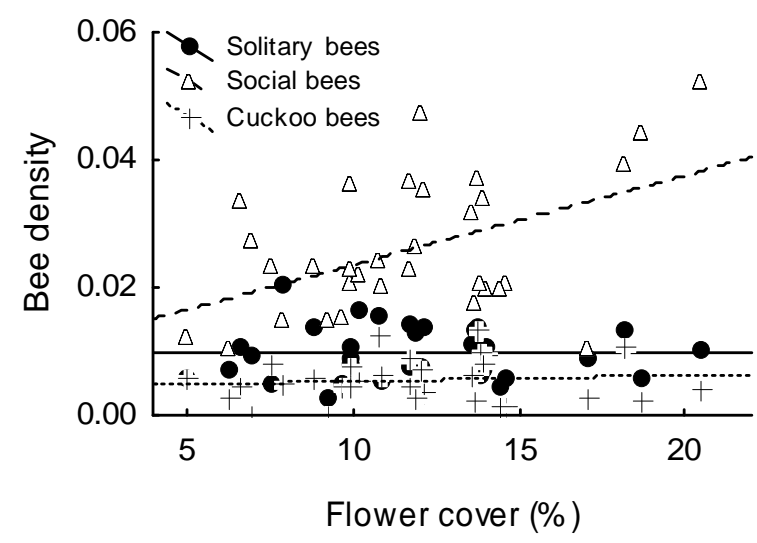

Figure 6: Relationship between densities of solitary (889 individuals), social (2502 individuals), and cuckoo (522 individuals) bees and average flower cover in percent of 32 calcareous grasslands.

\section{Discussion}

\section{Species-area relationship}

A reduction in habitat area is generally expected to have a strong, negative impact on biodiversity (Fahrig 2003). In our study, we can show a highly significant effect of decreasing size in calcareous grassland fragments on bee species richness. These results confirm typical species-area relationships that were previously demonstrated in a few other studies of bees in subtropical dry forest (Aizen and Feinsinger 1994), limestone quarries (Steffan-Dewenter et al. 2006), orchard meadows (Steffan-Dewenter 2003) and desert scrub (Cane et al. 2006). 
Small patches with local populations that go extinct because of disturbances or demographic stochasticity might not become recolonised as fast from neighbouring populations as populations on large patches, hence a greater species richness on large than on small habitat islands is expected (MacArthur and Wilson 1967).

Even though the calcareous grasslands in our study represent well defined islands of species-rich semi-natural habitat in an agricultural landscape, that provide foraging as well as nesting habitat for bees, one has to be careful applying the predictions of the theory of island biogeography to terrestrial habitats (Haila 2002) because the matrix may be permeable to bees (Andren 1994) and even provide additional foraging and nesting habitat. According to Rosenzweig (1995), mainland areas get recolonised so fast that the immigration rate does not determine their diversities. Species on non-isolated mainland habitats are therefore estimated to have a $z$-value (slope of log-log regression of species-area curves that indicate the sensitivity of a species to habitat loss) between $0.13-0.18$, whereas species on oceanic islands or isolated mainland habitats have an estimated $z$-value between $0.25-0.33$. A review by Watling and Donnelly (2006) revealed significant differences in $z$-values between true islands $($ mean $=0.259)$ and terrestrial patches within an agricultural matrix $($ mean $=0.183)$. The $z-$ value of all bee species in our study was $z=0.22$ ( $z=0.21$ for estimated species richness), a value that is very high for mainland habitats. However, this value is in accordance with other high $z$-values in observations of trap-nesting bees in orchard meadows $(z=0.23)$ (SteffanDewenter 2003) and solitary bees in limestone quarries $(z=0.33)$ (Steffan-Dewenter et al. 2006). These high values indicating a high sensitivity of bees to habitat loss might be explained by the conservative dispersal strategy and high nest site fidelity of solitary bees (Westrich 1989a).

Other insect groups show a lower sensitivity to habitat loss; Krauss et al. (2003) found a $z$-value of 0.16 for butterflies on the same calcareous grasslands. This may be because species richness does not only increase because of area per se but also because habitat diversity increases per unit area, providing microhabitats for different plant and animal species (Rosenzweig 1995). Whereas caterpillars develop directly on their host plant and butterfly diversity is only dependent on increasing plant diversity (Öckinger and Smith 2006), bees, on the other hand, build nests for their offspring. Hence they need calcareous grasslands that provide not only high plant diversity but also a wide variety of nesting sites e.g. abandoned rodent burrows, pithy or hollow plant stems, soil with suitable texture and vegetation cover, abandoned beetle burrows in dead wood, wall cavities, empty snail-shells 
etc. and nesting materials like leaves, petals, plant hairs, resin, clay, and small stones. Therefore, bees depend more on habitat size and increased habitat diversity than butterflies.

\section{Abundance-area relationship}

The equilibrium theory of island biogeography presumes that the population density for species groups remains constant with increasing area of habitat fragments (MacArthur and Wilson 1967). Our data support this theory because we found the same density of bee communities on small as well as on large sites. Our results are consistent with other studies where pollinator densities of bees (Steffan-Dewenter 2003) and butterflies (Öckinger and Smith 2006) did not correspond to an increase in habitat size. However, there are also studies that found significant increases of pollinator density with an increase in size of habitat fragments for bees (Aizen and Feinsinger 1994) and butterflies (Krauss et al. 2003). We can only conclude that abundance-area relationships remain much more ambiguous than speciesarea relationships as they might depend more on resource availability than area per se.

\section{Effects of body size on species-area relationships}

Not all species groups are expected to be equally affected by habitat fragmentation (Ewers and Didham 2006). Species at higher trophic levels (Dupont and Nielsen 2006), species with specific habitat or food requirements (Steffan-Dewenter and Tscharntke 2000), or species with poor dispersal abilities (Öckinger and Smith 2006) are generally more strongly affected by fragmentation.

Body size of a bee species is positively correlated with its foraging distance (Gathmann and Tscharntke 2002; Westphal et al. 2006). Small bees with consequently a small flight range will need a higher density of available food and nesting resources per unit area than larger and more mobile bee species (Cresswell et al. 2000). Large calcareous grasslands do have higher flowering plant species richness and flower cover, thus provide foraging as well as nesting sites in one place and are therefore more suitable for small bees with poor dispersal abilities. Large bees can afford to have spatially separate nesting and foraging sites due to their better dispersal abilities and can therefore utilize small and large calcareous grasslands equally well.

Because small grasslands contain only small populations with higher risk of extinction, viable populations of bee species depend on immigration. Large, mobile bee species can more easily colonise new patches so their greater dispersal rates might counterbalance assumed higher extinction rates in small fragments. 
The few existing studies comparing responses of pollinating insects differing in body size to area loss have been ambiguous (Steffan-Dewenter and Tscharntke 2000; Shahabuddin and Ponte 2005; Cane et al. 2006). However, our results clearly demonstrate that small bees are much more sensitive to area loss than large bees. Log-log regressions of species-area relationships give significantly different $z$-values for small $(z=0.32)$ and for large $(z=0.19)$ bee species. Density of small bees also increases strongly with increasing fragment size whereas density of large bees remained the same over fragments of all sizes. We can conclude that small bees with poor dispersal abilities are more prone to the effects of habitat loss.

\section{Sociality}

In addition to body size, susceptibility to area loss may depend on other life history traits such as solitary vs. social and nest-building versus cleptoparasitic. We observed differential responses of bees with different breeding strategies to a decrease in habitat size. The species-area relationship was strongest for solitary bees $(z=0.28)$, significantly less steep in social species $(z=0.14)$ and intermediate for cuckoo bees $(z=0.22)$.

Comparing species-area relationship of social versus non-social bees, SteffanDewenter et al. (2006) found similar results, i.e. $z=0.42$ for solitary and $z=0.16$ for social species. Contrary to their study, we can not attribute the observed effect to the immense dispersal ability of bumblebees (Walther-Hellwig and Frankl 2000; Westphal et al. 2006) because we found an almost equal distribution of the large Bombus (9 species) and the usually smaller Halictus / Lasioglossum ( 8 social species). However, social bees can be considered to be more generalist than solitary bees because the provisioning of larvae requires higher quantities of food to be brought to a colony of social bees than to a single nest of solitary bees. Stronger species-area relationships for specialist pollinators than for generalists have been demonstrated for butterflies (Steffan-Dewenter and Tscharntke 2000; Krauss et al. 2003) and bees (Steffan-Dewenter et al. 2006; Cane et al. 2006). The typically more generalist social bee species also take more advantage of matrix resources (Westphal et al. 2003) and their distribution should therefore also depend on the availability of mass flowering crops around their nesting sites.

\section{Cleptoparasitic bees}

Species at higher trophic levels might be more affected by reduced habitat area because they depend on the occurrence of species at lower trophic levels (Holt et al. 1999). Cleptoparasitic bees depend on the occurrence of nest-building species as they feed on the host's brood cell provisions. Comparing species-area relationships of cuckoo versus nest- 
building bees, Steffan-Dewenter et al. (2006) found the slope for cleptoparasitic species to be steeper than for nest-building species $(z=0.36$ versus $z=0.29)$. Contrary to this, the slope of species-area curves in our study was steeper for nest-building $(z=0.28)$ than for cleptoparasitic $(z=0.22)$ species. The slopes, however, are not significantly different. The ambiguous results may be explained by the fact that, unlike the females of most social and solitary bee species which are central place foragers, cleptoparasites are not. They do not commute between foraging places and a nest because provisioning of the brood cell is done by the host. Cuckoo bees may therefore disperse widely across the landscape and this higher mobility may obscure the effect of trophic rank on the strength of the species-area relationship.

\section{Connectivity}

The connectivity between calcareous grasslands in our study region did not have a positive effect on species richness or population densities of bee communities. This result is in accordance with 54 of 81 reviewed studies (Watling and Donnelly 2006) that showed no relationship between species richness and isolation. Our inability to find isolation effects may be explained by several factors: Firstly by the relatively low degree of isolation in our study region; grasslands were always less than $2 \mathrm{~km}$ away from their nearest neighbour. Because the foraging range of solitary bees is 150-400 $\mathrm{m}$ (Gathmann and Tscharntke 2002), of bumblebees up to $3000 \mathrm{~m}$ (Westphal et al. 2006), immigration events are probably common. Secondly, present-day species distributions may be a result of historical habitat connectivity (Helm et al. 2006) that has been lost due to habitat destruction and land use intensification and many local extinction events may not yet have occurred. And lastly, because the agricultural landscape matrix around habitat patches may not be hostile, but instead offer corridors and stepping stones of field margins, hedgerows, fallows or orchard meadows.

\section{Landscape diversity}

The effective isolation of habitat fragments that determines their species composition may be greatly influenced by the surrounding landscape quality (Ricketts 2001) and in order to accurately explain species' responses to habitat fragmentation, landscape factors need to be considered. The influence of landscape context on abundance and species richness has been shown before (Kleijn and van Langevelde 2006; Bergman et al. 2004) but empirical analysis of matrix quality in fragmentation studies has rarely been done (but see Krauss et al. 2003; Öckinger and Smith 2006). Even though we did not find any interactions between landscape diversity and habitat fragmentation, landscape diversity was important in determining the 
density and species richness of bees on calcareous grasslands. High diversity of the surrounding landscape implies the presence of habitats other than arable land and forest, which are the most abundant habitat types in the region, namely other grasslands, fallows, orchard meadows, hedgerows and gardens. These habitats provide additional foraging plants and a variety of nesting resources for bee species (Steffan-Dewenter and Tscharntke 2002), thereby enhancing population growth of different species and also increasing the permeability of the matrix, facilitating colonization and reducing extinction rates in habitat fragments (Ricketts 2001).

Landscape diversity at the scale of $250 \mathrm{~m}$ radius around the centre of the calcareous grasslands turned out to be the best predictor for species richness and density of bees; scales up to $750 \mathrm{~m}$ were significant for bee density. Our results support findings where the proportion of semi-natural habitat on small scales up to $750 \mathrm{~m}$ showed a positive correlation with species richness and abundance of solitary bees (Steffan-Dewenter et al. 2002). Interestingly, it is the landscape directly adjacent to the calcareous grasslands that is most relevant to the bees. This can be attributed to the foraging ranges of solitary bees that lie between 150 and $400 \mathrm{~m}$ (Gathmann and Tscharntke 2002). A habitat with rewarding resources within the foraging range of the bee's nest may enhance population density and species persistence. Bumble bees have foraging ranges, depending on the species, from 500 to $3000 \mathrm{~m}$ (Westphal et al. 2006); however, large bees did not respond to landscape diversity at larger spatial scales than small bees.

\section{Resource availability}

The percent flower cover on habitat fragments was the most important factor determining density of bees on calcareous grasslands. Dependency of pollinator abundance on their floral resources is self-evident and has been shown before (e.g. Potts et al. 2003; Hegland and Boeke 2006). More interesting is the strong dependence of social bee density on resource availability compared to solitary and cuckoo bees. Our results confirm studies by Hines and Hendrix (2005) and Kleijn and van Langevelde (2006) who found a positive relationship between bumble bee abundance and the availability of floral resources. Social bees have nests with many individuals; up to 600 individuals in Bombus terrestris colonies (von Hagen and Aichhorn 2003). Hence, they need to collect large amounts of food to provision their numerous offspring. A larger amount of available resources therefore supports larger colonies. 


\section{Conservation implications}

The empirical evidence presented here suggests that pollinator diversity is profoundly dependent on the availability of semi-natural habitats such as calcareous grasslands. Therefore, nature conservation agencies and agri-environment schemes need to continue and expand support for extensive management on this protected biotope by sheep herders, land managers, and environmental organisations whose work prevents calcareous grasslands from succession to scrubland and forest. Management practices should especially aim at preserving or creating habitat heterogeneity on the grasslands and also enhancing flower availability that increases bee density on calcareous grasslands.

We also showed that species richness and density is further dependent on a complex landscape around the grasslands. Therefore, in addition to the protection of semi-natural habitat patches, management schemes for conservation of bees as key pollinators should also take into account spatial scales larger than single habitat fragments. They should aim to preserve heterogeneity of landscapes, thereby providing a greater array of food and nesting resources and offering corridors to reduce patch isolation. Agri-environmental schemes that have already been implemented (organic farming, creation and restoration of field margins and flowering strips, hedgerow planting and restoration, extensification of grasslands, etc.) need to be continued and expanded. Further research on the relative importance of different scheme types is needed. Organic agriculture for example increases floral diversity and abundance, especially in structurally simple landscapes (Gabriel et al. 2006) and leads to higher bee diversity (Holzschuh et al. 2007). The resulting rise in pollinator diversity and abundance from agri-environmental schemes will secure pollination services to wild and crop plants thereby preserving plant species richness and abundance on semi-natural habitats and increasing crop yield on farmland. 
Appendix 1: Overall abundance, frequency (number of sites where a species was found), mean body length, and breeding strategy of 110 bee species on 32 calcareous grasslands in Lower Saxony, Germany

\begin{tabular}{|c|c|c|c|c|c|}
\hline Species & Abundance & Frequency & \multicolumn{2}{|c|}{ Mean body length } & Breeding strategy \\
\hline Andrena angustior & 4 & 2 & 11 & large & solitary \\
\hline Andrena bicolor & 10 & 6 & 10 & small & solitary \\
\hline Andrena carantonica & 5 & 5 & 13 & large & solitary \\
\hline Andrena chrysosceles & 19 & 10 & 9 & small & solitary \\
\hline Andrena cineraria & 4 & 4 & 12.5 & large & solitary \\
\hline Andrena falsifica & 15 & 8 & 6.25 & small & solitary \\
\hline Andrena flavipes & 28 & 11 & 10.75 & large & solitary \\
\hline Andrena fucata & 18 & 8 & 11 & large & solitary \\
\hline Andrena fulvago & 6 & 4 & 9.5 & small & solitary \\
\hline Andrena gravida & 8 & 7 & 13.25 & large & solitary \\
\hline Andrena haemorrhoa & 16 & 10 & 10.25 & large & solitary \\
\hline Andrena helvola & 3 & 3 & 10 & small & solitary \\
\hline Andrena humilis & 1 & 1 & 10.75 & large & solitary \\
\hline Andrena intermedia & 1 & 1 & 10.5 & large & solitary \\
\hline Andrena labialis & 2 & 1 & 12.5 & large & solitary \\
\hline Andrena labiata & 5 & 4 & 8.5 & small & solitary \\
\hline Andrena minutula & 52 & 21 & 6.25 & small & solitary \\
\hline Andrena minutuloides & 34 & 10 & 6.25 & small & solitary \\
\hline Andrena nigroaenea & 28 & 14 & 13.5 & large & solitary \\
\hline Andrena nitida & 27 & 15 & 12.75 & large & solitary \\
\hline Andrena proxima & 6 & 2 & 9.25 & small & solitary \\
\hline Andrena strohmella & 11 & 8 & 7 & small & solitary \\
\hline Andrena subopaca & 52 & 21 & 6.5 & small & solitary \\
\hline Andrena wilkella & 8 & 6 & 9.75 & small & solitary \\
\hline Anthidium manicatum & 1 & 1 & 13.75 & large & solitary \\
\hline Anthidium punctatum & 1 & 1 & 8.875 & small & solitary \\
\hline Anthidium strigatum & 17 & 11 & 6.5 & small & solitary \\
\hline Anthophora plumipes & 6 & 5 & 15 & large & solitary \\
\hline Apis mellifera & 769 & 26 & 14.75 & large & highly eusocial \\
\hline Bombus hortorum & 4 & 4 & 15.25 & large & social \\
\hline Bombus hypnorum & 4 & 4 & 14.5 & large & social \\
\hline Bombus lapidarius & 902 & 32 & 16 & large & social \\
\hline Bombus lucorum & 3 & 3 & 15 & large & social \\
\hline Bombus pascuorum & 454 & 32 & 13.25 & large & social \\
\hline Bombus pratorum & 12 & 8 & 12.5 & large & social \\
\hline Bombus soroeensis & 4 & 4 & 13.25 & large & social \\
\hline Bombus sylvarum & 1 & 1 & 13.5 & large & social \\
\hline Bombus terrestris & 296 & 31 & 16 & large & social \\
\hline Ceratina cyanea & 8 & 6 & 6.5 & small & solitary \\
\hline Chelostoma campanularum & 10 & 8 & 5.625 & small & solitary \\
\hline Chelostoma florisomne & 2 & 2 & 9.25 & small & solitary \\
\hline Chelostoma rapunculi & 17 & 11 & 9 & small & solitary \\
\hline Colletes cunicularius & 4 & 3 & 13 & large & solitary \\
\hline Colletes daviesanus & 1 & 1 & 8.625 & small & solitary \\
\hline Eucera nigrescens & 3 & 2 & 14.5 & large & solitary \\
\hline Halictus maculatus & 3 & 2 & 8.25 & small & social \\
\hline Halictus rubicundus & 72 & 10 & 10.25 & large & social \\
\hline Halictus simplex & 23 & 1 & 9.75 & small & solitary \\
\hline Halictus tumulorum & 266 & 26 & 7 & small & social \\
\hline Heriades truncorum & 3 & 3 & 7.375 & small & solitary \\
\hline Hylaeus annularis & 1 & 1 & 6.125 & small & solitary \\
\hline Hylaeus brevicornis & 5 & 4 & 4.75 & small & solitary \\
\hline Hylaeus communis & 9 & 7 & 5.75 & small & solitary \\
\hline Hylaeus confusus & 11 & 7 & 6.75 & small & solitary \\
\hline Hylaeus gredleri & 2 & 2 & 5.125 & small & solitary \\
\hline Hylaeus nigritus & 5 & 2 & 7.375 & small & Solitary \\
\hline
\end{tabular}


Appendix 1 (continued): Overall abundance, frequency (number of sites where a species was found), mean body length and breeding strategy of 110 bee species on 32 calcareous grasslands in Lower Saxony, Germany

\begin{tabular}{|c|c|c|c|c|c|}
\hline Species & Abundance & Frequency & \multicolumn{2}{|c|}{ Mean body length } & Breeding strategy \\
\hline Lasioglossum albipes & 15 & 7 & 7.75 & small & no information \\
\hline Lasioglossum calceatum & 31 & 18 & 8.75 & small & social \\
\hline Lasioglossum fulvicorne & 44 & 17 & 6.75 & small & solitary \\
\hline Lasioglossum laticeps & 3 & 3 & 6.75 & small & social \\
\hline Lasioglossum lativentre & 1 & 1 & 7 & small & solitary \\
\hline Lasioglossum leucopus & 7 & 7 & 5 & small & solitary \\
\hline Lasioglossum leucozonium & 1 & 1 & 8.75 & small & solitary \\
\hline Lasioglossum lineare & 6 & 1 & 7 & small & social \\
\hline Lasioglossum lucidulum & 1 & 1 & 4.5 & small & no information \\
\hline Lasioglossum minutulum & 1 & 1 & 6.5 & small & solitary \\
\hline Lasioglossum morio & 185 & 23 & 5.5 & small & social \\
\hline Lasioglossum parvulum & 1 & 1 & 6 & small & solitary \\
\hline Lasioglossum pauxillum & 256 & 26 & 5.5 & small & social \\
\hline Lasioglossum pygmaeum & 9 & 5 & 5.75 & small & no information \\
\hline Lasioglossum villosulum & 81 & 18 & 6.5 & small & solitary \\
\hline Megachile apicalis & 2 & 1 & 10 & small & solitary \\
\hline Megachile versicolor & 3 & 3 & 10.75 & large & solitary \\
\hline Megachile willughbiella & 3 & 3 & 14 & large & solitary \\
\hline Melecta albifrons & 2 & 2 & 14.75 & large & cuckoo \\
\hline Melitta haemorrhoidalis & 9 & 3 & 12 & large & solitary \\
\hline Melitta leporina & 1 & 1 & 11.75 & large & solitary \\
\hline Nomada bifasciata & 3 & 3 & 10.75 & large & cuckoo \\
\hline Nomada fabriciana & 7 & 4 & 8.75 & small & cuckoo \\
\hline Nomada flava & 19 & 12 & 11.75 & large & cuckoo \\
\hline Nomada flavoguttata & 61 & 20 & 6 & small & cuckoo \\
\hline Nomada fucata & 12 & 7 & 9 & small & cuckoo \\
\hline Nomada goodeniana & 8 & 7 & 11.75 & large & cuckoo \\
\hline Nomada guttulata & 1 & 1 & 7.5 & small & cuckoo \\
\hline Nomada lathburiana & 2 & 2 & 11.25 & large & cuckoo \\
\hline Nomada marshamella & 27 & 16 & 11.25 & large & cuckoo \\
\hline Nomada panzeri & 1 & 1 & 8.5 & small & cuckoo \\
\hline Nomada ruficornis & 27 & 13 & 9.25 & small & cuckoo \\
\hline Nomada sexfasciata & 4 & 2 & 13 & large & cuckoo \\
\hline Nomada sheppardana & 27 & 7 & 5.75 & small & cuckoo \\
\hline Nomada succincta & 46 & 22 & 11.25 & large & cuckoo \\
\hline Osmia aurulenta & 17 & 6 & 10.25 & large & solitary \\
\hline Osmia bicolor & 205 & 28 & 9.75 & small & solitary \\
\hline Osmia leaiana & 3 & 2 & 8.75 & small & solitary \\
\hline Osmia rufa & 10 & 4 & 11.25 & large & solitary \\
\hline Osmia spinulosa & 6 & 4 & 7.5 & small & solitary \\
\hline Osmia uncinata & 2 & 2 & 9 & small & solitary \\
\hline Psithyrus bohemicus & 13 & 12 & 20.25 & large & cuckoo \\
\hline Psithyrus campestris & 1 & 1 & 18.25 & large & cuckoo \\
\hline Psithyrus rupestris & 10 & 8 & 17.5 & large & cuckoo \\
\hline Psithyrus sylvestris & 9 & 5 & 14.5 & large & cuckoo \\
\hline Sphecodes crassus & 19 & 10 & 6 & small & cuckoo \\
\hline Sphecodes ephippius & 110 & 21 & 6.75 & small & cuckoo \\
\hline Sphecodes ferruginatus & 40 & 9 & 7.25 & small & cuckoo \\
\hline Sphecodes geoffrellus & 1 & 1 & 5.5 & small & cuckoo \\
\hline Sphecodes gibbus & 20 & 10 & 9.75 & small & cuckoo \\
\hline Sphecodes hyalinatus & 30 & 8 & 5.75 & small & cuckoo \\
\hline Sphecodes monilicornis & 10 & 6 & 8.5 & small & cuckoo \\
\hline Sphecodes niger & 10 & 6 & 5.25 & small & cuckoo \\
\hline Sphecodes rufiventris & 2 & 2 & 8 & small & cuckoo \\
\hline
\end{tabular}


CHAPTER

3

CONTRASTING RESPONSES OF

SPECIES RICHNESS AND DENSITY OF HOVERFLIES

(DIPTERA: SYRPHIDAE)

TO AGRICULTURAL LAND-USE CHANGE

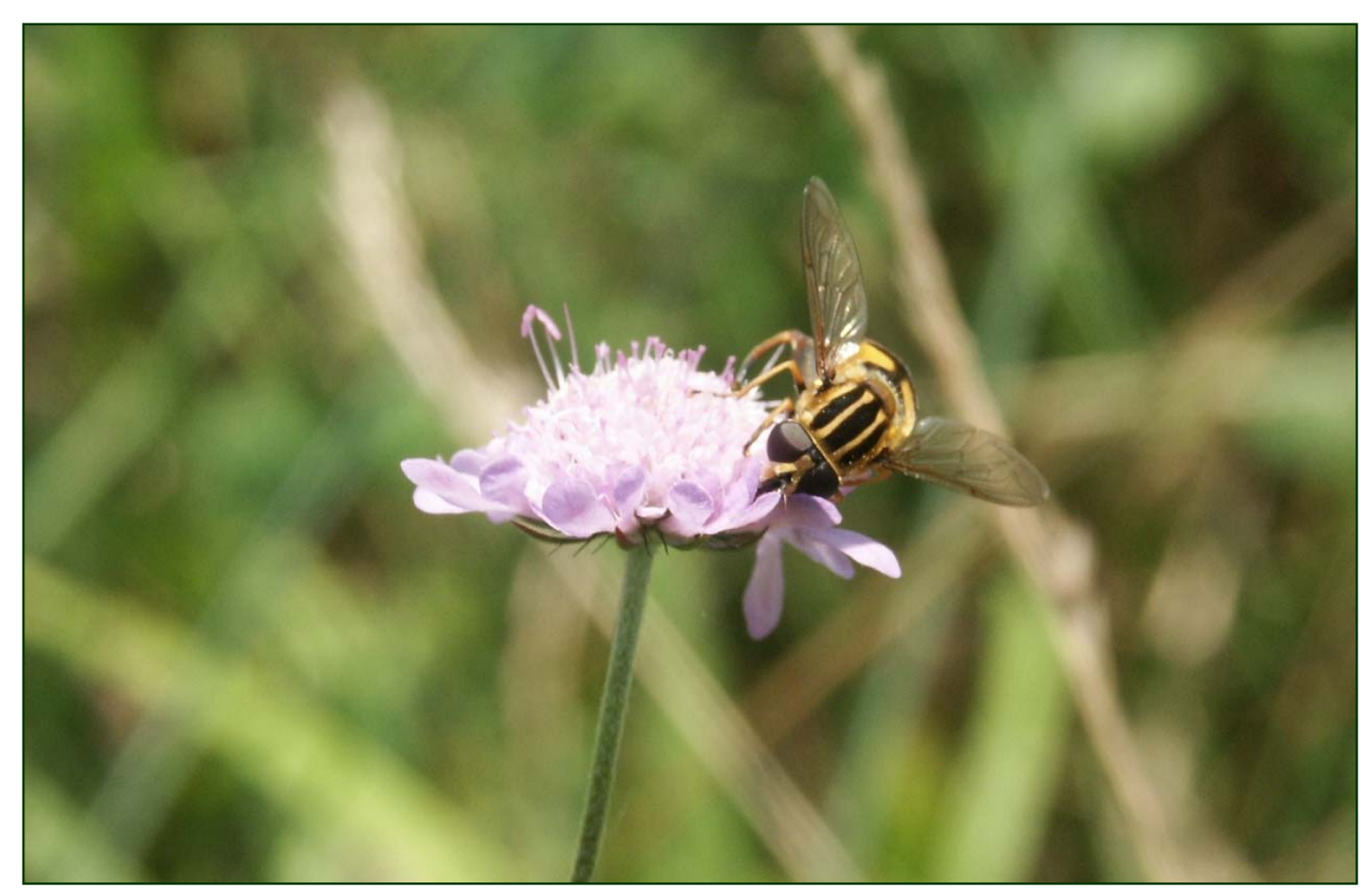




\section{Abstract}

Hoverflies in agroecosystems have gained much attention recently because the larvae of some species are efficient control agents of crop aphids and adult hoverflies provide pollination services to wild flowers and flowering crops. Hence, it is of great value to determine habitat- and landscape-level factors that drive hoverfly communities in agricultural landscapes. We assessed density and species richness of hoverflies on 32 calcareous grasslands, constituting a semi-natural habitat for adult hoverflies, via six transect walks from April to September 2004. Our results show that both, local habitat factors and landscape factors, influenced hoverflies, and that their effects on species richness and density were quite contrary. Hoverfly species richness was affected by qualitative factors such as the species richness of flowering plants, the area of calcareous grasslands (with increased habitat heterogeneity on larger fragments), and a diverse landscape offering various micro- and macrohabitats for adults and larvae. Hoverfly abundance, in contrast, depended on quantitative factors such as the amount of pollen and nectar resources for adults and the availability of larval macrohabitats in the surrounding matrix. Most interestingly, species guilds responded to specific land-use types such as annual crops and woodland at different spatial scales indicating variation in mobility and the degree of spillover effects among neighbouring landscape elements. We conclude that, in order to maintain abundant and species rich hoverfly communities in agricultural landscapes, both, adult and larval habitat requirements, have to be met.

\section{Zusammenfassung}

Der Bedeutung von Schwebfliegen in der Agrarlandschaft ist unlängst stärker in den wissenschaftlichen Fokus gerückt, da ihre Larven wichtige Gegenspieler der Blattläuse auf landwirtschaftlichen Flächen darstellen und die adulten Tiere zur Bestäubung von Wild- und Kulturpflanzen beitragen. Es ist daher von großer Bedeutung, Faktoren zu finden, die die Schwebfliegengemeinschaften auf lokaler und landschaftlicher Ebene in Agrarlandschaften bestimmen. Der Artenreichtum und die Dichte der Schwebfliegen wurden mittels sechs Transektbegehungen von April bis September 2004 auf 32 Kalkmagerrasen, die ein naturnahes Adulthabitat darstellen, erfasst. Unsere Ergebnisse zeigen, dass sowohl lokale als auch Landschaftsfaktoren die Schwebfliegengemeinschaften beeinflussten und dass sich der Artenreichtum und die Dichte in ihrer Reaktion gegenläufig verhielten. Der Artenreichtum wurde durch qualitative Faktoren wie dem Blütenpflanzenreichtum, der Habitatgröße (mit einer höheren Habitatheterogenität auf größeren Magerrasen) und der Landschaftsdiversität 
bestimmt, die alle zu einer Verfügbarkeit diverser Mikro- und Makrohabitate für Larven und Imagines beitragen. Im Gegensatz dazu wurde die Schwebfliegendichte von quantitativen Faktoren wie der Menge der Pollen- und Nektarressourcen für Imagines und dem Anteil der Larvalhabitate in der umgebenden Landschaftsmatrix determiniert. Die unterschiedlichen Gilden reagierten auf die spezifischen Larvalhabitate auf verschiedenen Skalenebenen, was auf unterschiedliche Mobilität und differenzierten Grad der räumlichen Übertragungseffekte zwischen den benachbarten Landnutzungen schließen lässt. Aus unseren Ergebnissen schließen wir, dass sowohl die Habitatansprüche der Imagines als auch die der Larven erfüllt sein müssen, um individuenstarke und artenreiche Schwebfliegengemeinschaften in der Agrarlandschaft zu erhalten.

Keywords: Functional groups, Habitat fragmentation, Land-use intensification, Larval habitat requirements, Pollinators, Resource availability, Spatial scales, Species-area relationships

\section{Introduction}

Recently the importance of hoverflies (Diptera: Syrphidae) in agricultural landscapes gained much attention in ecological studies. Two valuable ecosystem services are often strongly connected to hoverfly occurrence: Larvae of many species are efficient biocontrol agents for aphid populations on crops (Tenhumberg and Poehling 1995) and adult hoverflies provide pollination services to wild flowers and crops (Sugiura 1996; Vance et al. 2004).

In modern agroecosystems, however, hoverflies are facing considerable challenges because of agricultural intensification. Species with aphidophagous larvae feeding on aphid colonies in crops are susceptible to pesticide applications (Niehoff and Poehling 1995). Other species are adversely affected by monotonous agricultural landscapes, as these landscapes lack specific macro- and microhabitats for the highly differentiated and diverse larval feeding habits in the hoverfly family. Further, reduced availability of flower-rich semi-natural habitats (Tscharntke et al. 2005) and lack of wild flowers in arable fields (Gabriel et al. 2006) are limiting the nectar resources needed for high energy flight and pollen resources needed by females for egg maturation (Haslett 1989).

Calcareous grasslands, established centuries ago by land-use practices like sheep- and goat-herding (Poschlod and WallisDeVries 2002), offer nectar and pollen resources of many different plant species from early spring to late fall and therefore represent a potential source habitat for hoverfly populations in agricultural landscapes (Duelli and Obrist 2003). In recent decades, however, as traditional land-use practices became uneconomical, many calcareous 
grasslands were replaced by intensively managed agricultural land-use types or abandoned to natural succession (Poschlod and WallisDeVries 2002). The suitability of calcareous grasslands as hoverfly habitat may depend on the size of the remaining grassland fragments (Ouin et al. 2006) with corresponding availability of microhabitats for different larval guilds, and availability of pollen and nectar resources for adults (Kleijn and van Langevelde 2006).

At the landscape scale, accessibility of diverse habitats is important especially for those hoverflies that need to switch between different habitats for foraging, mating, larval development, and overwintering. Whereas coverage of semi-natural habitats increases overall species richness (Kleijn and van Langevelde 2006), different guilds may depend differently on certain land-use types within the agricultural landscape (Schweiger et al. 2007). While forest is generally considered the most species rich land-use type because it offers many overwintering and larval microhabitats (Speight 2006), arable land is the most abundant landuse type in agricultural landscapes and may positively influence aphidophagous species feeding in crops. Thus, agricultural landscapes of the temperate regions are potentially suitable for hoverflies, and may in turn greatly profit from ecological services as biological pest control and pollination.

By assessing hoverfly communities on semi-natural calcareous grassland fragments, we addressed the following hypotheses:

1. Size and quality of calcareous grassland habitat positively influence hoverfly diversity and density.

2. Landscape diversity increases overall species richness of hoverflies.

3. Availability of different land-use types, i.e. forest and arable land positively affects species with respective larval macrohabitat requirements.

\section{Methods}

\section{Study region and site characteristics}

The study was conducted in 2004 in the Leine-Bergland in Lower Saxony, Germany. The study region covers an area of about $1,944 \mathrm{~km}^{2}$ and is mostly dominated by intensively managed arable land (42.2 \%) and forest (36.8 \%) (ATKIS-DLM 25/1 Landesvermessung und Geobasisinformationen Niedersachsen 1991-1996, Hannover Germany; ATKIS-DLM 25/2 Hessisches Landesvermessungsamt 1996, Kassel, Germany). Calcareous grasslands are patchily distributed fragments of semi-natural habitats in this agricultural landscape and cover only about $0.3 \%$ of the area. Calcareous grasslands occur on shallow, lime-rich soils, usually on south or south-west facing slopes. They belong to the plant association Gentiano- 
Koelerietum and are managed by sheep- or goat-herding, extensive mowing, or annual removal of woody shrubs.

We selected 32 calcareous grasslands around the city of Göttingen embedded within landscapes of varying complexity and covering gradients of habitat area, flowering plant species richness, and floral abundance. The percent land cover of eleven different land-use types (arable land, forest, grassland, built-up area, garden land, hedgerows, calcareous grasslands, orchard meadows, fen, plantations, and other habitat) was measured at twelve different spatial scales ranging from 250 to $3000 \mathrm{~m}$ radius around the centre of the calcareous grasslands using Geographic Information Systems (GIS, ARC/View 3.2 ESRI Geoinformatik, Hannover, Germany). Percent cover of the two most abundant land-use types, arable land and forest, ranged from 7.5 to 99.0 and 0.0 to $69.7 \%$, respectively. Percent cover of the eleven different land-use types was further used to calculate landscape diversity $\left(H^{\prime}\right)$ on each of the twelve scales applying the Shannon-Wiener index (Krebs 1989). The area of the calcareous grassland fragments was measured with a differential GPS GEOmeter 12L (GEOsat GmbH, Wuppertal, Germany) and ranged from $314-51,395 \mathrm{~m}^{2}$. Resource availability was quantified after each pollinator sampling date by determining all plant species in flower within the sampled area and estimating their percent floral cover. Flower diversity ranged from 24 to 56 flowering species per site, flower cover ranged from 5.0 to $20.5 \%$.

\section{Pollinator sampling}

Hoverflies (Diptera: Syrphidae) were sampled via transect walks six times from April to September 2004 on 32 calcareous grasslands. Syrphidae within a 4 m corridor were either identified on the wing (Episyrphus balteatus, Syritta pipiens, Eristalis tenax) or caught with a net and identified in the lab (van Veen 2004). Some individuals could not be identified to species level and were either determined to genus level (Heringia spec., Paragus spec., and Pipizella spec.) or to species groups (Cheilosia albitarsis/ranunculi, Eumerus strigatus/sogdianus, Melanostoma mellinum/scalare, Pipiza bimaculata/noctiluca, and Platycheirus scutatus/splendidus). All study sites were sampled in a randomized sequence between 0900 and 1800 hours on sunny days with little wind. To achieve adequate sample sizes, transect time varied from 20 min on eleven small fragments (314-1,133 $\mathrm{m}^{2}$ ) over 40 min on 13 medium fragments $\left(1,326-7,887 \mathrm{~m}^{2}\right)$ to $60 \mathrm{~min}$ on eight large fragments $(11,528$ $51,395 \mathrm{~m}^{2}$ ). Total transect time was divided into 5 min subunits. Transect length per subunit was measured to calculate syrphid abundance per square meter. Species numbers and abundance of all hoverflies were pooled for each study site over the sampling period.

According to their larval macrohabitat requirements, hoverfly species were assigned to 
groups of crop and forest species using a database on the biological traits of European hoverflies (“Syrph the Net”, Speight 2006; Monteil 2006, Appendix 1). Forest hoverflies are diverse species with zoophagous, saprophagous, and phytophagous larval feeding types. They occur in coniferous or deciduous forests as their preferred habitat and use various microsites such as trunk cavities, rot holes, tree sap runs, forest litter, dung, and woodland basidiomycetes. Crop hoverflies are mostly zoophagous species that feed on aphids in annual crops. When both crop and forest were cited as the preferred macrohabitats, we assigned species to crop as it was the most dominant and variable land-use type in the study region. Thus, some crop species may also be associated with forest in some part of their life cycle, whereas all forest species were strictly limited to woodlands.

\section{Statistical analyses}

The statistical analyses of the hoverfly data were carried out using R, Version 2.3.1 ( $R$ development core team 2006). We calculated multiple regressions using type I sums of squares. This means, terms were added sequentially, from first to the last term, to the null model containing only the intercept. This procedure allows terms in the model to be correlated and hypotheses to become conditionally dependent upon one another (Schmid et al. 2002). The sequence of explanatory variables that entered the model was (1) landscape diversity, (2) habitat area, (3) species richness of flowering plants, and (4) flower cover. All response variables were tested for meeting the assumptions of normality and homoscedasticity and were log10-transformed when necessary.

Table 1. Pearson correlation coefficients $(r)$ for the independent variables of the 32 calcareous grasslands. Habitat area was log10-transformed.

\begin{tabular}{lcccc}
\hline & $\begin{array}{c}\text { Habitat area } \\
{\left[\mathrm{m}^{2}\right]}\end{array}$ & $\begin{array}{c}\text { Landscape diversity } \\
\text { (radius: 250 m) }\end{array}$ & $\begin{array}{c}\text { Landscape diversity } \\
\text { (radius: 750 m) }\end{array}$ & $\begin{array}{c}\text { Cover of plant } \\
\text { species in flower }\end{array}$ \\
\hline Landscape diversity (radius $250 \mathrm{~m}$ ) & $0.32^{(*)}$ & & & \\
Landscape diversity (radius $750 \mathrm{~m})$ & $0.32^{(*)}$ & $0.72^{* * *}$ & 0.16 & 0.18 n.s. \\
Cover of plant species in flower & $0.38^{*}$ & $0.16 \mathrm{n} . \mathrm{s}$. & 0.24 & 0.23 n.s. \\
Species richness of flowering plants & $0.54^{* * *}$ & 0.24 & & \\
\hline
\end{tabular}

Significance levels: *** $P<0.001$; ** $P<0.01$; * $P<0.05$; $\left.{ }^{*}\right) P<0.1$; n.s. $=$ not significant

Because the landscape diversity within the twelve different landscape scales correlated significantly with each other, we determined the most relevant spatial scales with simple correlations and used only one scale in each multiple regression (250 m for species richness and $750 \mathrm{~m}$ for syrphid density). Habitat area was marginally correlated with landscape diversity at the 250 and the 750 m radius and significantly correlated with the diversity and 
percent cover of flowering plants (Table 1). Because the correlation between habitat area and flower diversity was strong (Pearson- $r>0.5$ ), we tested different orders of these two factors in the regression models.

The subunits of the transect walks were used in rarefaction methods to correct for the different sampling efforts on small, medium, and large calcareous grassland fragments (Gotelli and Colwell 2001). We estimated the species number on four subunits on each site simulating even sampling on study sites of differing sizes and we calculated the second-order Jackknife richness estimator for overall species richness using EstimateS, Version 7.5 (Colwell 2004). To avoid effects of season-dependent species turnover, we pooled the first, second, third etc. 5 min subunits of all six transect walks per site.

For identifying scale dependency and the importance of larval feeding habitat, we correlated i) overall species richness and density with landscape diversity, ii) species richness and density of aphidophagous crop-associated species with percent arable land, and iii) species richness and density of forest-associated species with percent forest cover on twelve spatial scales from 250 to 3000 m radius around the calcareous grasslands.

\section{Results}

Altogether 3560 hoverfly individuals representing 75 species or species groups were sampled (Appendix A). The most ubiquitous and by far the most abundant species was Episyrphus balteatus, occurring on all sites and making up $41.18 \%$ of all individuals. Other frequent and abundant hoverflies were Sphaerophoria scripta (16.35\%), Syrphus vitripennis (7.33 \%), Eristalis tenax (6.69 \%), and Syrphus torvus (4.35 \%).

Almost two thirds of all collected hoverfly individuals prefer crop as their main macrohabitat. These 2297 individuals constitute only eleven species. Even though not identified to species, Melanostoma mellinum/scalare was determined a crop species because crop is cited as the preferred habitat for both species. A large number of species, 43 species with 1114 individuals, have forest as their preferred habitat. All Heringia species occurring in Lower Saxony and both species of Platycheirus scutatus/splendidus are associated with forest.

Size and quality of calcareous grasslands

Because both flower diversity and habitat area were strongly correlated with each other, we constructed two alternative models with habitat area either entered before or after flower diversity. When habitat area was fitted after flower diversity, both habitat area $\left(F_{1,27}=25.50, \quad P<0.001\right)$ and flower diversity $\left(F_{1,27}=36.13, \quad P<0.001\right)$ had highly 
significant effects on hoverfly species richness. If fitted before flower diversity (Table 2), habitat area still had a highly significant effect $\left(F_{1,27}=54.76, P<0.001\right)$, while flower diversity slightly decreased in significance $\left(F_{1,27}=6.87, P=0.014\right)$. Hence, the area of calcareous grassland habitats and the species richness of flowering plants on these habitats were important factors in determining the species richness of hoverflies (Table 2).

Table 2. Multiple regression analysis of the relationship between species richness (sampled, estimated overall, and estimated in four subunits) and densities of hoverflies, and the independent factors landscape diversity (radius of $250 \mathrm{~m}$ around centre for species richness, $750 \mathrm{~m}$ for densities), habitat area, flower diversity, and flower cover of the 32 calcareous grasslands (d.f. = 1, 27). Habitat area and hoverfly densities were log10transformed. Given are $r^{2}$ of the total model, $F$-values and the direction of the regression for significant factors.

\begin{tabular}{lcccccccc}
\hline & \multicolumn{2}{c}{$\begin{array}{c}\text { Sampled hoverfly } \\
\text { species richness }\end{array}$} & \multicolumn{2}{c}{$\begin{array}{c}\text { Estimated overall } \\
\text { species richness }\end{array}$} & \multicolumn{2}{c}{$\begin{array}{c}\text { Estimated richness in } \\
\text { four subunits }\end{array}$} & \multicolumn{2}{c}{ Hoverfly density } \\
\hline Multiple $r^{2}$ & \multicolumn{2}{c}{0.73} & \multicolumn{2}{c}{0.68} & \multicolumn{2}{c}{0.31} & \multicolumn{2}{c}{0.37} \\
& F-value & Direction & F-value & Direction & F-value & Direction & F-value & Direction \\
Landscape diversity & $14.03^{* * *}$ & + & $10.21^{* *}$ & + & 1.60 & n.s. & $4.58^{*}$ & - \\
Habitat area & $54.76^{* * *}$ & + & $40.75^{* * *}$ & + & $3.44^{* *}$ & + & 2.13 & n.s. \\
Flower diversity & $6.87^{*}$ & + & $5.14^{*}$ & + & $5.83^{*}$ & + & 2.02 & n.s. \\
Flower cover & 1.17 & n.s. & 0.13 & n.s. & 1.47 & n.s. & $6.48^{*}$ & + \\
\hline
\end{tabular}

Significance levels: *** $P<0.001 ; * * P<0.01 ; * P<0.05$; $^{(*)} P<0.1$; n.s. $=$ not significant

Species numbers increased significantly with increasing size of grassland fragments (Fig. 1) and with increasing flowering plant diversity (Fig. 2). The species-area-relationship was significant for sampled species richness as well as for overall species richness estimated with the second-order Jackknife richness estimator and marginally significant for the species richness estimated for four subunits (Table 2).

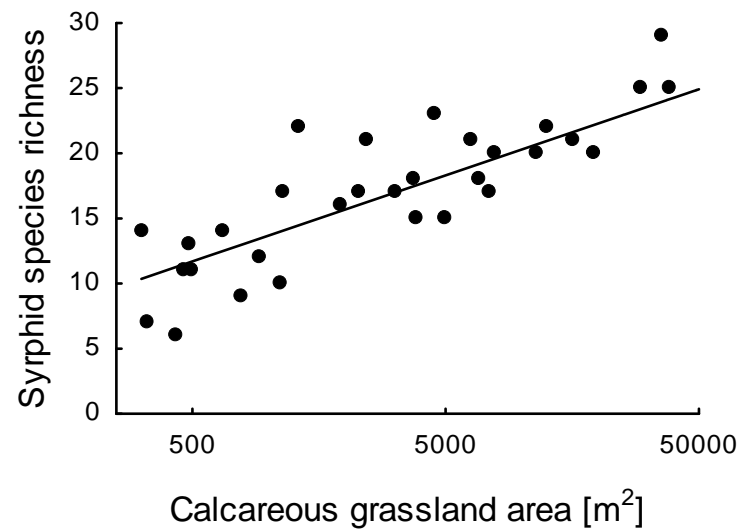

Figure 1. Relation between syrphid species richness and area of 32 calcareous grasslands $\left(F_{1,27}=54.76, P<0.001\right)$.

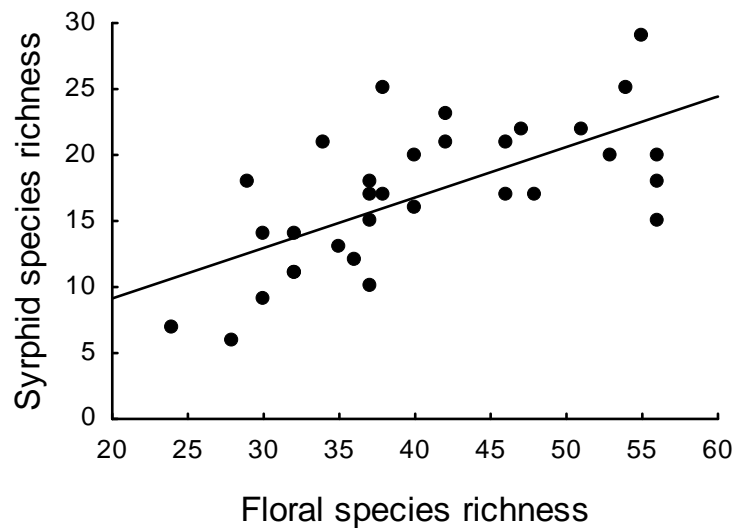

Figure 2. Relation between species richness of syrphid flies and flowering plants on 32 calcareous grasslands $\left(F_{1,27}=6.87, P=0.014\right)$. 
Whereas floral species richness influenced hoverfly species richness, abundance of floral resources influenced hoverfly density (Table 2); more hoverflies were caught on grasslands with high availability of flowering plants (Fig. 3). Area of calcareous grasslands did not have an effect on hoverfly density.

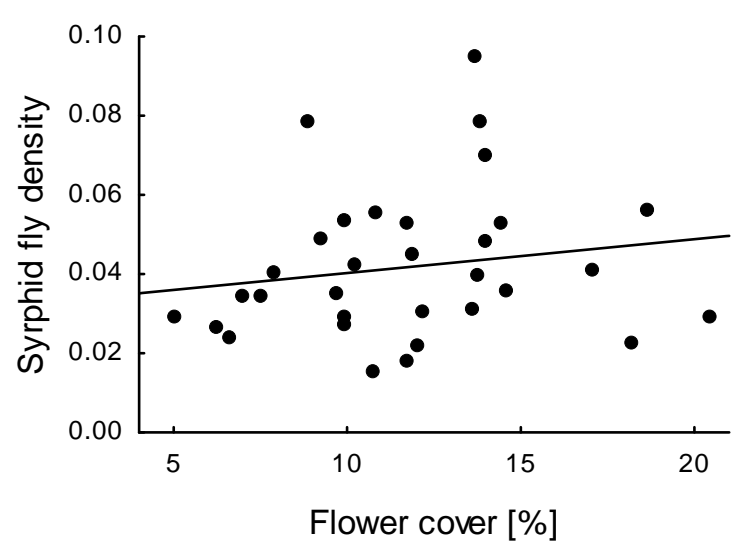

Landscape diversity
Figure 3. Relation between syrphid abundance per $\mathrm{m}^{2}$ and average flower cover in percent of 32 calcareous grasslands $\left(F_{1,27}=6.48, P=0.017\right)$.

When landscape diversity increased within a $250 \mathrm{~m}$ radius around the calcareous grasslands, species richness of hoverflies increased as well (Table 2, Fig. 4A). Contrary to species richness, density of hoverflies was negatively influenced by an increase in landscape diversity within a $750 \mathrm{~m}$ radius around the grassland fragments (Table 2, Fig. 4A). In the study region, landscape diversity is inversely related to the percent cover of arable land (Pearson- $r=-0.65, P<0.001$ ), but not correlated with forest (Pearson- $r=-0.01, P=0.953$ ). Because hoverfly abundance was made up to a large extent by species that might rely on specific larval habitats such as annual crops (64.5 \% of all individuals) or forests (31.3 \%) for larval development, we correlated species richness and density of these two groups with the availability of their larval habitat. Density of crop-aphidophagous hoverflies were positively correlated with the percent cover of arable land (Fig. 4B). This effect was most significant at the $750 \mathrm{~m}$ scale. Density of obligate forest hoverflies was highly correlated with the percent cover of woodland (Fig. 4C), reacting most strongly at scales from 750 to $1500 \mathrm{~m}$ radius around the grasslands. Whereas species richness of crop hoverflies did not correlate with percent cover of arable land, species richness of forest hoverflies positively correlated with the amount of available woodland. These correlations were strongest at scales of 1250 and $1500 \mathrm{~m}$ around the grassland fragments. 
(A) Landscape diversity

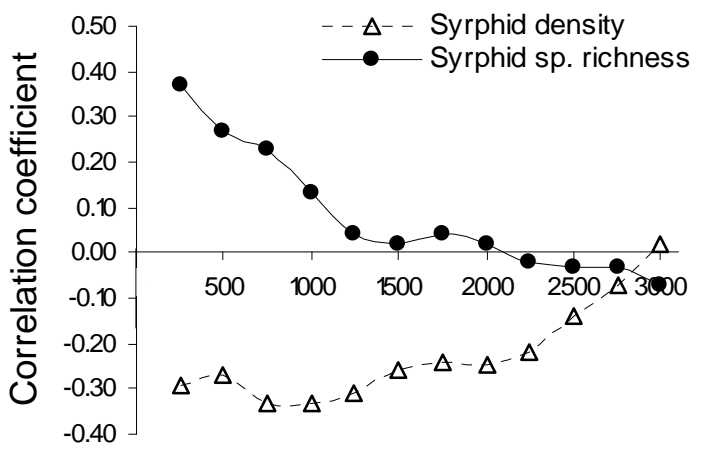

(B) Arable land

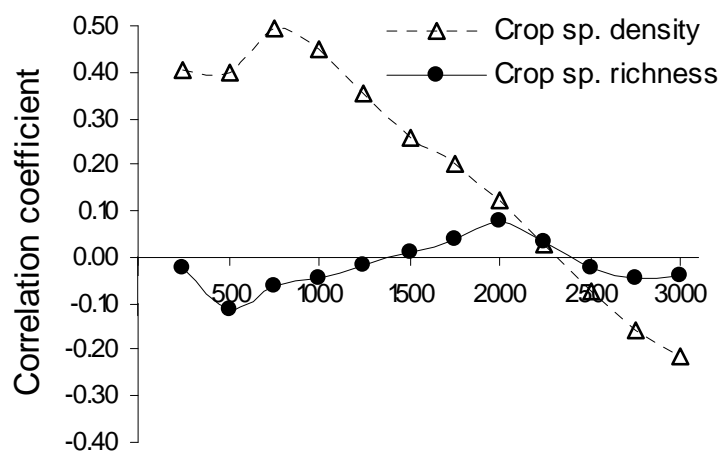

(C) Forest

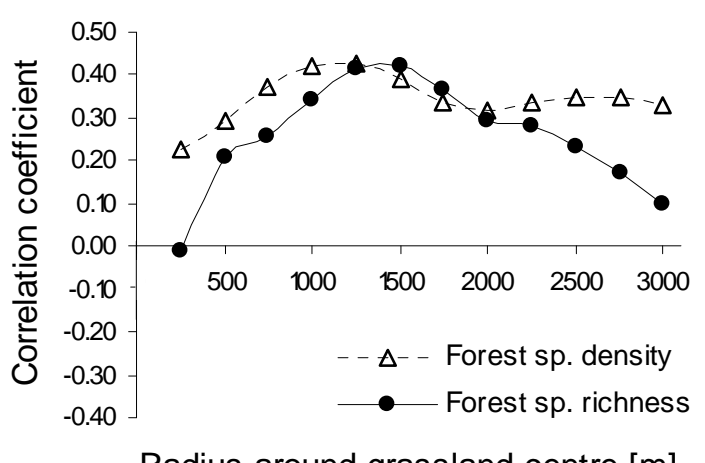

Radius around grassland centre $[\mathrm{m}]$

Figure 4. Pearson correlation coefficients between syrphid density and species richness of (A) all syrphid flies versus landscape diversity (Shannon-Wiener index); (B) crop species versus the percentage of arable land; and (C) forest species versus the percentage of forest on twelve different scales ranging from 250 to $3000 \mathrm{~m}$ radius around 32 calcareous grasslands. Coefficients larger than 0.35 denote a significant correlation $(P<0.05)$.

\section{Discussion}

On a local scale, we found a significant species-area relationship of hoverflies on calcareous grasslands. An increase in hoverfly species richness with increasing habitat area has recently been shown for forest fragments in France (Ouin et al. 2006), but the observed 
species-area relationship was attributed to a sampling effect (Rosenzweig 1995). The authors argue that uniform sampling in small and large patches would have underestimated richness in large patches because of increased habitat heterogeneity (Schoereder et al. 2004) and suggest applying rarefaction methods in future analyses of species-area relationships (Gotelli and Colwell 2001). In our study, we found significant species-area relationships for uniform sampling size and for estimated species richness using rarefaction methods on semi-natural grassland fragments, ruling out a sampling effect as the only explanation for species-arearelationships. Large habitat fragments support diverse hoverfly communities with stable populations that are less prone to extinctions than small hoverfly populations in small grassland fragments (Whittaker 1998). Unlike species number, abundance was not dependent on habitat size, but on the flower cover on the study sites (Kleijn and van Langevelde 2006). Adult syrphids need nectar for high-energy hovering flight and females need pollen as a protein source for reproduction (Haslett 1989). Therefore calcareous grassland fragments with high amounts of flowering plants are attractive and can support a large number of hoverflies.

High habitat heterogeneity on large fragments might be another factor explaining the observed species area relationship (Rosenzweig 1995). Species richness of flowering plants, one component of habitat heterogeneity of the calcareous grassland habitat, even though highly correlated with habitat size, still explained much of the variation not explained by habitat area. Adult hoverflies are usually polylectic, visiting a wide range of plants that provide large amounts of nectar and pollen and are easily reached by their short proboscis (Branquart and Hemptinne 2000). Phytophagous hoverfly larvae, however, are often more specialised and sometimes feed only on certain plant families, genera, or even species (e.g. Cheilosia fraterna on Cirsium palustre; Ch. ranunculi on Ranunculus bulbosus, Speight 2006), thus explaining the strong dependency on plant diversity. Because larval requirements of hoverflies are highly differentiated, other unrecorded factors of habitat heterogeneity may additionally account for the observed species-area relationship. For example, large calcareous grasslands may offer more rotting logs to xylophagous species; ant, wasp, and bumble bee nests to specialised zoophagous hoverflies; and sheep dung for coprophagous species compared to small grassland fragments.

Heterogeneity was further of importance to hoverflies on a larger landscape scale, i.e. increased species richness was observed in habitats embedded within a highly diverse landscape matrix. Although exhibiting species-area relationships, calcareous grassland are not necessarily islands in a hostile and thus uninhabited matrix (Ricketts 2001). Complex landscapes are composed of many different habitat types such as hedgerows, woodlands, 
ponds, pasture, and crop fields, all of potential importance to larvae of many different functional groups and feeding habits (Schweiger et al. 2007). Hence, a diverse landscape may facilitate hoverfly movement between optimal habitats or support a diverse hoverfly community themselves (Kleijn and van Langevelde 2006; Burgio and Sommaggio 2007; Hendrickx et al. 2007).

The response of hoverfly density to landscape diversity was directly opposed to the response of hoverfly species richness as we observed more hoverfly individuals in homogenous landscapes. According to Schweiger et al. (2007), land-use change differentially affects different groups of hoverfly species depending e.g. on the specific larval food and microhabitat. Hoverflies are traditionally considered to be associated with forest habitats where overwintering and larval development of many species takes place (Branquart and Hemptinne 2000). Accordingly, we found increased numbers of forest dwelling hoverflies on grasslands with high amounts of woodland in the surrounding landscape. We also observed increased species richness, because woodlands offer various microhabitats for many hoverfly species, e.g. aphids on coniferous or deciduous trees, decaying wood, sap runs, tiny ponds between branches, or basidiomycete fungi (Speight et al. 2006). The negative effect of landscape diversity on overall hoverfly density is largely due to the most dominant hoverfly guild, i.e. species whose larvae feed on aphids in annual crops, because the amount of arable land is inversely related to landscape diversity. As aphidophagous larvae in monotonous annual crops show no niche differentiation into microhabitats (Sadeghi and Gilbert 2000), we did not observe an increase in species richness of crop dwelling species with increasing amount of arable land. Like in all hoverfly species, the adults of the aphidophagous guild need pollen and nectar resources and hence profit from high floral abundances and a diverse landscape.

Whereas landscape diversity was correlated strongest to overall species richness on the smallest scale of $250 \mathrm{~m}$, abundance was affected at larger scales; $750 \mathrm{~m}$ for aphidophagous and 750-1500 $\mathrm{m}$ for forest species. These scales are higher than the maximum $200 \mathrm{~m}$ foraging ranges suggested for three aphidophagous species by Wratten et al. (2003) and instead support findings of Kleijn and van Langevelde (2006) who suggest that hoverflies are optimally related to landscape context on scales of 500-1000 m. Hence, species richness is composed of many but less abundant and less mobile species, and density is mainly made up by a few, but extremely abundant and very mobile species. Especially species such as $E$. balteatus, the most abundant and highly mobile species, is likely to disperse in high numbers out of larval crop habitats into flower rich calcareous grassland habitats when the former 
become unsuitable for adults. However, little is known about the temporal and spatial dynamics of such spill-over processes in agricultural landscapes (Rand and Louda 2006).

\section{Conclusions}

Hoverfly species richness depended on qualitative factors such as the diversity of flowering plants, the area of calcareous grasslands by means of increased habitat heterogeneity on larger fragments, and a diverse landscape. Hoverfly abundance on the other hand was affected by quantitative factors such as the amount of floral resources on the habitat fragments and the availability of larval habitat in the landscape.

To ensure ecosystem functions that hoverflies provide, such as pollination and biological pest control, one might chose abundance of pollinators with aphidophagous larvae as the target species. It would seem that ubiquitous hoverflies such as E. balteatus, that are effective antagonists to aphids as larvae (Tenhumberg and Poehling 1995) and pollinators on flowering crops such as rape (Jauker, unpublished data) as adults, might be the species of the highest interest. Thus, increasing crop land to a certain extent would still sufficiently support the hoverfly guild which is most relevant for ecosystem services. However, too much arable land, as measured on large scales, depresses even crop-associated hoverfly species, most likely because suitable adult feeding habitat becomes the limiting factor (Jervis and Kidd 1996). Most importantly, increased density is gained at the cost of diversity, both in species richness and functional diversity (Fontaine et al. 2006). Conservation of functional and taxonomic diversity, however, has been determined the major goal of conservation efforts worldwide as declared in the Convention on Biological Diversity signed in Rio de Janeiro in 1992 by 189 countries.

Hence a well balanced landscape providing woodland area and crops as well as large semi-natural habitats such as calcareous grasslands, orchard meadows, pasture, fallows, and hedgerows with high abundance and diversity of flowering plants is needed to preserve species richness and abundance of hoverflies and corresponding functional diversity in an agricultural landscape. 
Appendix 1. Overall abundance, frequency (number of sites where a species was found), and larval feeding habit of 75 syrphid species or species groups on 32 calcareous grasslands in Lower Saxony, Germany. Denoted are species that have forest (F) or crop (C) as their preferred macrohabitat according to information from Syrph the Net ((Monteil 2006) Speight et al. 2006).

\begin{tabular}{|c|c|c|c|}
\hline Syrphid species & Abundance & Frequency & Larval feeding habit \\
\hline Caliprobola speciosa & 1 & 1 & xylophagous $^{\mathrm{F}}$ \\
\hline Cheilosia albitarsis/ranunculi & 16 & 10 & phytophagous \\
\hline Cheilosia antiqua & 1 & 1 & phytophagous \\
\hline Cheilosia barbata & 5 & 4 & phytophagous \\
\hline Cheilosia flavipes & 3 & 2 & phytophagous \\
\hline Cheilosia fraterna & 1 & 1 & phytophagous \\
\hline Cheilosia impressa & 2 & 2 & phytophagous \\
\hline Cheilosia lenis & 1 & 1 & phytophagous \\
\hline Cheilosia nebulosa & 2 & 1 & phytophagous $^{F}$ \\
\hline Cheilosia psilophthalma & 1 & 1 & phytophagous \\
\hline Cheilosia scutellata & 1 & 1 & phytophagous $^{\mathrm{F}}$ \\
\hline Cheilosia soror & 31 & 17 & phytophagous $^{\mathrm{F}}$ \\
\hline Cheilosia vernalis & 1 & 1 & phytophagous \\
\hline Cheilosia vulpina & 5 & 4 & phytophagous $^{\mathrm{C}}$ \\
\hline Chrysogaster solstitialis & 4 & 1 & saprophagous $^{\mathrm{F}}$ \\
\hline Chrysotoxum bicinctum & 14 & 8 & zoophagous (aphids) ${ }^{\mathrm{F}}$ \\
\hline Chrysotoxum cautum & 4 & 3 & zoophagous \\
\hline Chrysotoxum verralli & 1 & 1 & zoophagous (aphids) \\
\hline Criorhina floccosa & 1 & 1 & saprophagous ${ }^{\mathrm{F}}$ \\
\hline Dasysyrphus albostriatus & 2 & 2 & zoophagous $^{\mathrm{F}}$ \\
\hline Dasysyrphus tricinctus & 1 & 1 & zoophagous $^{\mathrm{F}}$ \\
\hline Didea fasciata & 4 & 4 & zoophagous (aphids) ${ }^{\mathrm{F}}$ \\
\hline Didea intermedia & 1 & 1 & zoophagous (aphids) ${ }^{\mathrm{F}}$ \\
\hline Epistrophe eligans & 16 & 12 & zoophagous (aphids) $^{\mathrm{C}}$ \\
\hline Epistrophe grossulariae & 4 & 2 & zoophagous (aphids) $^{\mathrm{F}}$ \\
\hline Episyrphus balteatus & 1466 & 32 & zoophagous (aphids) ${ }^{\mathrm{C}}$ \\
\hline Eristalis arbustorum & 34 & 14 & saprophagous ${ }^{\mathrm{F}}$ \\
\hline Eristalis interrupta & 88 & 22 & saprophagous $^{\mathrm{F}}$ \\
\hline Eristalis intricaria & 2 & 2 & saprophagous $^{\mathrm{F}}$ \\
\hline Eristalis lineata & 6 & 4 & saprophagous $^{\mathrm{F}}$ \\
\hline Eristalis pertinax & 76 & 22 & saprophagous ${ }^{\mathrm{F}}$ \\
\hline Eristalis tenax & 238 & 30 & saprophagous $^{\mathrm{F}}$ \\
\hline Eumerus ornatus & 3 & 2 & sapro/phytophagous \\
\hline Eumerus strigatus/sogdianus & 3 & 2 & sapro/phytophagous \\
\hline Eumerus tricolor & 4 & 2 & sapro/phytophagous $^{\mathrm{F}}$ \\
\hline Eupeodes corollae & 39 & 16 & zoophagous (aphids) ${ }^{\mathrm{C}}$ \\
\hline Eupeodes luniger & 2 & 2 & zoophagous (aphids) ${ }^{C}$ \\
\hline Eupeodes nitens & 1 & 1 & zoophagous (aphids) ${ }^{\mathrm{F}}$ \\
\hline Ferdinandea cuprea & 2 & 2 & sapro/xylophagous $^{F}$ \\
\hline Helophilus hybridus & 3 & 2 & saprophagous \\
\hline Helophilus pendulus & 25 & 15 & saprophagous $^{F}$ \\
\hline Helophilus trivittatus & 26 & 11 & saprophagous \\
\hline Heringia heringi & 1 & 1 & zoophagous $^{\mathrm{F}}$ \\
\hline Herinqia spec. & 7 & 6 & zoophagous $^{\mathrm{F}}$ \\
\hline
\end{tabular}


Appendix 1. (continued)

\begin{tabular}{|c|c|c|c|}
\hline Syrphid species & Abundance & Frequency & Larval feeding habit \\
\hline Lapposyrphus lapponicus & 10 & 9 & zoophagous (aphids) ${ }^{\mathrm{F}}$ \\
\hline Melanostoma mellinum/scalare & 74 & 26 & phyto-/zoophagous (aphids) ${ }^{\mathrm{C}}$ \\
\hline Meligramma cincta & 2 & 1 & zoophagous (aphids) $^{\mathrm{F}}$ \\
\hline Meliscaeva auricollis & 2 & 2 & zoophagous (aphids) ${ }^{\mathrm{C}}$ \\
\hline Meliscaeva cinctella & 1 & 1 & zoophagous (aphids) ${ }^{\mathrm{F}}$ \\
\hline Merodon equestris & 3 & 3 & sapro/phytophagous ${ }^{\mathrm{F}}$ \\
\hline Microdon mutabilis & 4 & 4 & zoophagous \\
\hline Myathropa florea & 35 & 15 & sapro/xylophagous $^{\mathrm{F}}$ \\
\hline Neoascia podagrica & 1 & 1 & saprophagous $^{\mathrm{F}}$ \\
\hline Paragus spec. & 8 & 8 & zoophagous \\
\hline Pipiza bimaculata/noctiluca & 5 & 3 & zoophagous (aphids) \\
\hline Pipizella spec. & 38 & 16 & zoophagous \\
\hline Platycheirus albimanus & 3 & 2 & zoophagous (aphids) ${ }^{\mathrm{C}}$ \\
\hline Platycheirus europaeus & 1 & 1 & zoophagous (aphids) ${ }^{\mathrm{F}}$ \\
\hline Platycheirus scutatus/splendidus & 1 & 1 & zoophagous (aphids) $^{\mathrm{F}}$ \\
\hline Rhingia campestris & 2 & 2 & saprophagous $^{\mathrm{F}}$ \\
\hline Scaeva pyrastri & 18 & 12 & zoophagous (aphids) ${ }^{\mathrm{C}}$ \\
\hline Scaeva selenitica & 28 & 7 & zoophagous (aphids) $^{\mathrm{F}}$ \\
\hline Sericomyia silentis & 1 & 1 & saprophagous $^{\mathrm{F}}$ \\
\hline Sphaerophoria scripta & 582 & 32 & zoophagous (aphids) ${ }^{\mathrm{C}}$ \\
\hline Syritta pipiens & 48 & 18 & saprophagous $^{\mathrm{F}}$ \\
\hline Syrphus ribesii & 90 & 26 & zoophagous (aphids) ${ }^{\mathrm{C}}$ \\
\hline Syrphus torvus & 155 & 23 & zoophagous (aphids) ${ }^{\mathrm{F}}$ \\
\hline Syrphus vitripennis & 261 & 30 & zoophagous (aphids) ${ }^{\mathrm{F}}$ \\
\hline Volucella bombylans & 8 & 6 & zoophagous $^{\mathrm{F}}$ \\
\hline Volucella pellucens & 2 & 2 & sapro-/zoophagous $^{\mathrm{F}}$ \\
\hline Xanthandrus comtus & 2 & 2 & zoophagous ${ }^{\mathrm{F}}$ \\
\hline Xanthogramma citrofasciatum & 15 & 9 & zoophagous (aphids) \\
\hline Xanthogramma pedissequum & 8 & 7 & zoophagous (aphids) \\
\hline Xylota segnis & 2 & 2 & sapro-/xylophagous ${ }^{\mathrm{F}}$ \\
\hline Xylota sylvarum & 1 & 1 & saprophagous ${ }^{\mathrm{F}}$ \\
\hline
\end{tabular}


CHAPTER

4

LINKING FLOWER VISITATION, SEED SET, AND SEED PREDATION OF PRIMULA VERIS AT MULTIPLE SPATIAL SCALES

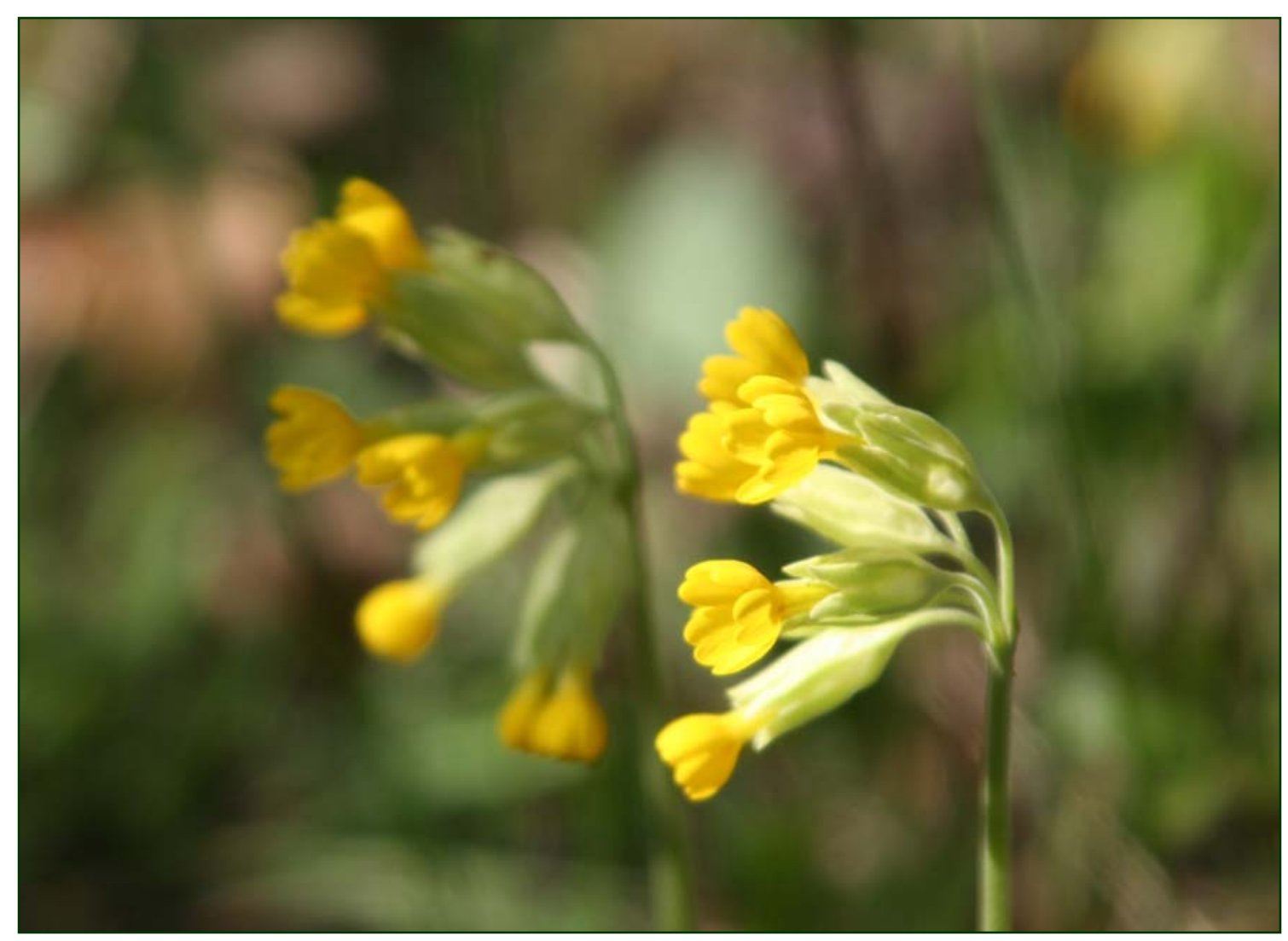




\section{Summary}

1 We examined pollination service, reproductive success, and seed predation of Primula veris, a self-incompatible, declining plant species in fragmented remnants of semi-natural habitats in an agricultural landscape in Germany. Mutualistic and antagonistic plant-insect interactions were analysed in differently sized patches of $P$. veris populations in calcareous grassland fragments of differing area that were surrounded by agricultural landscapes of differing complexity.

2 Pollinator abundance was positively influenced by factors at three different spatial scales: i) by increasing size of $P$. veris patches, ii) by increasing area of calcareous grassland fragments, and iii) by increasing landscape diversity around the fragments. Taxonomic richness of pollinators was positively influenced by an increase in patch size.

3 Seed set was strongly reduced in small patches which we propose is caused by pollen limitation due to the decreased pollinator abundance. Further evidence of pollination limitation was found in patches smaller than $1 \mathrm{~m}^{2}$ where hand-pollinated flowers set more seeds per fruit than open-pollinated flowers.

4 Seed predation by tortricid moths ranged from 0 to $100 \%$ of the examined fruits and was most profound in large calcareous grassland fragments.

5 Because pollination services responded to variables at smaller spatial scales than seed predation, we suggest considering multiple spatial scales when analysing mutualistic and antagonistic relationships of rare plant species.

Keywords: calcareous grasslands, habitat area, heterostylous, landscape diversity, patch size, pollination limitation, pollinators, rare plant species, reproductive success, self-incompatible

\section{Introduction}

Most of the nearly 250,000 angiosperms existing today are pollinated by animals and the majority, when analysed for fecundity, show evidence of pollination limitation (Burd 1994). A possible cause for pollination limitation is the decline of pollinators due to anthropogenic factors such as land use changes, use of agricultural pesticides and herbicides, and invasive species (Kearns et al. 1998). One of the most detrimental consequences of agricultural land use change is habitat fragmentation that is potentially disrupting plantpollinator interactions (Rathcke and Jules 1993). Semi-natural calcareous grasslands habitats are especially under threat from fragmentation because of the intensification of agriculture 
management and the abandonment of traditional land-use practices like sheep- or goatherding, (Poschlod and WallisDeVries 2002). Calcareous grasslands are among the habitats with the highest taxonomic diversity in Western Europe and harbour many rare plant species (Ellenberg 1996). Small and isolated habitat remnants support populations of these species only in small-sized patches that are more likely to go extinct than large populations (Fischer and Stöcklin 1997).

Fragmented plant populations suffer from pollinator limitation on two different spatial scales. First, a habitat reduced in size with limited availability of food and nesting resources supports less diverse pollinator communities at lower densities (Buchmann and Nabhan 1997). Second, small patches of flowering plants within the habitat fragments might lack ample rewards of nectar and pollen thereby failing to recruit sufficient numbers of resident pollinators (Rathcke 1983). Reduced pollinator abundance in agricultural landscapes may not be entirely due to fragmentation, but may also be caused by a third factor; the homogeneity of the landscape matrix that surrounds the plant populations (Weibull et al. 2000; SteffanDewenter et al. 2001; Morandin et al. 2007).

Declining pollinator abundances can lead to an insufficient supply of conspecific pollen to the plant stigma thereby preventing adequate fertilization of the ovules and reducing seed set. Pollinator limitation due to fragmentation is especially detrimental in selfincompatible, obligately out-crossing plant species which completely depend on pollinators for sexual reproduction (Aguilar et al. 2006).

Because reproductive success is ultimately determined by the number of seeds that will germinate and themselves produce offspring, studies analysing survival of plant populations need to consider not only the mutualistic relationship of a plant species with its pollinators but also antagonistic relationships such as pre-dispersal seed predation (Brody and Mitchell 1997).

In this study, we focus on Primula veris, a self-incompatible, perennial plant species that is declining in Central Europe due to the loss of nutrient-poor grassland habitat. To account for responses of biotic interactions at multiple spatial scales, we apply a nested design to analyse the effects of three different factors of agricultural land use change acting at different spatial scales, i.e. reduced patch size, area loss of calcareous grassland habitat, and reduced diversity of the surrounding landscape on pollinator abundance, seed set, and seed predation of $P$ veris. We further test for pollinator limitation by performing pollination experiments where seed set of hand-pollinated versus open-pollinated flowers is compared, and by relating measured seed set to observed flower visitation (Dafni et al. 2005). 


\section{Methods}

\section{Study species}

Primula veris L. (Primulaceae) is an herbaceous perennial hemicryptophyte that occurs in nutrient-poor grasslands and forest edges on calcareous soils in Europe and Asia (Philippi 1993). In our study area, the rosette first emerges in February; an umbel with up to 20 yellow deep-tubed flowers on a single stalk appears in April. Primula veris often forms a prominent yellow flowering cover in nutrient-poor calcareous grasslands in early spring. The flowers of $P$. veris are distylous and allogamous (Wedderburn and Richards 1990); only cross-pollination between the long-styled pin flowers and the short-styled thrum flowers results in seed set. The entomophilous $P$. veris is a generalist with respect to its pollinators, being visited by members of Hymenoptera, Diptera, Coleoptera and Lepidoptera (Woodell 1960). Most of the reproduction is sexually, but vegetative propagation by rhizomes may occur, forming clusters of ramets (Tamm 1972; Kéry et al. 2000). Primula veris is a longliving plant, lasting over 50 years in an adequate habitat (Inghe and Tamm 1988), but disappears when grasslands are abandoned to succession (Lindborg et al. 2005). Because of the fragmentation of its semi-natural calcareous grassland habitat, $P$. veris is an endangered species in the study region, included in the Red Data Book as "vulnerable" (Garve 1994).

\section{Study region and study sites}

The study region around the city of Göttingen in southern Lower Saxony, Germany, is characterized by intensively managed agricultural areas and patchily distributed fragments of semi-natural habitats. Calcareous grasslands, the habitat of P. veris, are highly fragmented and only cover about $0.3 \%$ of the area. They occur on nutrient-poor, shallow soils of calcareous rock on south or south-west facing slopes. Calcareous grasslands belong to the phytosociological association Gentiano-Koelerietum and contain a very species-rich flora with xero- and thermophilic plants (Ellenberg 1996).

In 2000 and 2005, we selected 16 and 15 calcareous grasslands with $P$. veris populations, respectively, of which eleven grasslands were common to both years resulting in 20 different sites over both years. Calcareous grassland fragments covered a gradient of size and landscape diversity. The area of the calcareous grassland fragments was measured in 2000 with a differential GPS GEOmeter 12L (GEOsat GmbH, Wuppertal, Germany) and ranged from 314 to $51,395 \mathrm{~m}^{2}$. The percent land cover of different habitat types (arable land, forest, grassland, built-up area, garden land, hedgerows, calcareous grasslands, orchard meadows, fen, plantations, and other habitats) was measured using Geographic Information Systems 
(GIS, ARC/View 3.2 ESRI Geoinformatik, Hannover, Germany). Landscape diversity $\left(H^{\prime}\right)$ was calculated at each of twelve different spatial scales ranging from 250 to $3000 \mathrm{~m}$ radius around the centre of the grasslands using the Shannon-Wiener index (Krebs 1989). Because landscape diversity of the twelve different landscape scales correlated significantly with each other, we used only the most significant landscape scale $(250 \mathrm{~m})$ for further analysis.

All $P$. veris individuals on a calcareous grassland fragment were defined as one population. The total population size on each study site was determined at the end of the flowering period by counting the total number of effective reproductive plants in populations of up to 2,000 individuals. In larger populations, P. veris individuals were estimated by determining plant abundance per $\mathrm{m}^{2}$ and multiplying by the populated area. Population size ranged from 411 to $c .100,000$ individuals.

In addition to habitat area and landscape diversity, we further analysed pollination of $P$. veris at the patch scale. A patch was defined as a subpopulation of $P$. veris that was at least $2 \mathrm{~m}$ apart from a neighbouring subpopulation. On each site we selected small $\left(<1 \mathrm{~m}^{2}\right)$, medium $\left(1-2 \mathrm{~m}^{2}\right)$, and large patches $\left(>2 \mathrm{~m}^{2}\right)$ wherever possible for a total of 45 patches in 2000 and 44 patches in 2005, ranging from 10 to 1,600 individuals $\left(0.1-37.0 \mathrm{~m}^{2}\right)$ per patch. This way we could analyse patches of different sizes nested within habitats of different area. Importantly, patch size and habitat area were not correlated (Table 1).

\section{Flower visitation observation, pollen supplementation, and seed collection}

In each patch, ten plants were randomly chosen and observed twice from April $18^{\text {th }}$ to $29^{\text {th }} 2000$ and three times from April $14^{\text {th }}$ to May $3^{\text {rd }}$ in 2005 . Observations took place between 0900 and 1730 hours on sunny days with little wind and at least $16^{\circ} \mathrm{C}$. All study sites were observed in a randomized sequence and at different times during the day. The observation time was 15 minutes each, in which all visitors were noted and identified on the wing to the lowest taxonomic level possible. Noted were also the number of inflorescences and the number of single flowers visited by each pollinator.

Ten additional plants per patch were randomly marked when flower buds first emerged. These open-pollinated plants were collected in July when the seeds had ripened. To assess pollination limitation, ten additional single flowers on five plants in each patch were randomly chosen, marked and cross-pollinated by hand with pollen from the opposite morph type of a neighbouring patch and collected when seeds had ripened. Fruits were dried at room temperature in paper bags and analysed for predation by insects. When a fruit was predated, usually all seeds were damaged and turned into crumbs. Seeds per plant were counted and divided by the number of non-predated fruits thereby using number of seeds per fruit as a 
measure of reproductive success.

\section{Statistical analyses}

For the analyses of flower visitation, data were pooled over the entire observation time; reproductive data were averaged per patch. The total population size of $P$. veris individuals was highly correlated with the area of calcareous grassland fragments and the number of plants per patch highly correlated with patch size (Table 1). For further analyses, we therefore used habitat area and patch size as measures for population and patch level analysis, respectively.

Table 1. Pearson correlation coefficients $(r)$ for the independent variables of 20 calcareous grasslands with 31 populations and 89 patches of Primula veris in 2000 and 2005. Correlations were calculated on patch $(n=89)$, population $(\mathrm{n}=31)$, and site scale $(\mathrm{n}=20)$, respectively. All variables except landscape diversity were $\log 10$ transformed for analyses.

\begin{tabular}{lcccc}
\hline & Patch size & Plants per patch & Population size & Calc. grassland area \\
\hline Plants per patch & $0.87^{* * *}$ & & & \\
Population size & 0.15 & 0.13 & & \\
Calc. grassland area & 0.14 & 0.08 & $0.62^{* * *}$ & \\
Landscape diversity & 0.05 & -0.06 & 0.24 & 0.42 \\
\hline
\end{tabular}

Significance levels: ${ }^{* *} P<0.001 ;{ }^{* *} P<0.01 ; * P<0.05 ;(*) P<0.1 ;$ n.s. $=$ not significant

The statistical analyses of the data were carried out using $\mathrm{R}$, Version 2.4.1 ( $\mathrm{R}$ Development Core Team 2006). All response variables were tested for meeting the assumptions of normality and homoscedasticity. Pollinator densities, richness, and seeds per fruit were square root-transformed; predation rates were arcsine-transformed for analyses.

To analyse flower visitation, seed set and seed predation on the different spatial scales of patch, habitat, and landscape, we applied a nested design with patch factors nested within site factors. We used linear mixed effects models (Pinheiro and Bates 2000) fitted by maximum likelihood in the nlme package (Version 3.1-79) of R 2.4.1. Fixed effects terms were added sequentially, and models differing in their fixed effects structures were compared using F-tests and Akaike information criterion (AIC, Burnham and Anderson 2002). The minimal adequate model was the one with the lowest AIC. The order of fixed effects terms was patch size, area of calcareous grassland fragments, and landscape diversity, while site identity was treated as random block factor. In order to predict the number of seeds, pollinator abundance and diversity were included in the model as fixed factors. We used paired t-tests to compare seed set of hand- versus open-pollinated flowers. 


\section{Results}

Pollinator abundance and diversity

In 2000, we observed 35 individuals of six bee species (Osmia bicolor, Bombus terrestris, Bombus pascuorum, Anthophora plumipes, Andrena haemorrhoa, Apis mellifera) and bombyliid flies during a total observation time of 1,350 minutes (Table 2). In 2005, altogether 237 individuals from 19 different taxa were observed in a total of 1,980 minutes (Table 2). With 0.39 and 1.80 pollinators per 15 minute-observation time, respectively, the average number of pollinators in 2000 was significantly different from 2005 (t-test, $P<0.001)$.

Table 2: Number of individuals and number of visited inflorescences for visitors of Primula veris in 30 min and 45 patches in 2000 and 45 min and 44 patches in 2005. Bombus terrestris agg. is a group of B. terrrestris and $B$. lucorum, which are difficult to distinguish in the field.

\begin{tabular}{|c|c|c|c|c|}
\hline & \multicolumn{2}{|c|}{2000} & \multicolumn{2}{|r|}{2005} \\
\hline & Individuals & $\begin{array}{c}\text { Visited } \\
\text { inflorescences }\end{array}$ & Individuals & $\begin{array}{c}\text { Visited } \\
\text { inflorescences }\end{array}$ \\
\hline \multicolumn{5}{|l|}{ Bees } \\
\hline Andrena spp. & 2 & 9 & 3 & 4 \\
\hline Anthophora plumipes & 8 & 21 & 33 & 73 \\
\hline Apis mellifera & 1 & 1 & & \\
\hline Bombus lapidarius & & & 1 & 3 \\
\hline Bombus pascuorum & 8 & 39 & 4 & 4 \\
\hline Bombus terrestris agg. & 5 & 19 & 8 & 17 \\
\hline Halictus/Lasioglossum spp. & & & 47 & 61 \\
\hline Osmia spp. & 4 & 11 & 2 & 4 \\
\hline \multicolumn{5}{|l|}{ Hover flies } \\
\hline Cheilosia spp. & & & 3 & 3 \\
\hline Epistrophe eligans & & & 2 & 2 \\
\hline Eupeodes spec. & & & 1 & 2 \\
\hline Melanostoma spec. & & & 1 & 1 \\
\hline Scaeva spec. & & & 1 & 1 \\
\hline other Syrphidae & & & 7 & 7 \\
\hline \multicolumn{5}{|l|}{ Bombyliid flies } \\
\hline Bombylius spp. & 7 & 11 & 72 & 113 \\
\hline \multicolumn{5}{|l|}{ Butterflies } \\
\hline Pieris spec. & & & 1 & 1 \\
\hline \multicolumn{5}{|l|}{ Beetles } \\
\hline Elateridae & & & 1 & 1 \\
\hline Meligethes spp. & & & 35 & 38 \\
\hline Mordellidae & & & 1 & 1 \\
\hline Staphilinidae & & & 14 & 16 \\
\hline Total & 35 & 111 & 237 & 352 \\
\hline
\end{tabular}


Pollinator observations in 2000 were very low and no significant effects of patch size, area of calcareous grassland, or landscape diversity on pollinator abundance or richness were found. In 2005, pollinator density (number of flower visitors on 10 plants) was determined by patch size, calcareous grassland area, and landscape diversity (Table 3): The number of pollinators increased significantly with increasing size of Primula patches (Fig. 1) and area of calcareous grassland fragments (Fig. 2). Pollinator density was further marginally influenced by an increase in landscape diversity within a $250 \mathrm{~m}$ radius around the centre of the calcareous grassland (Fig. 3). Taxonomic richness of pollinators visiting $P$. veris also increased significantly with increasing patch size (Table 3, Fig. 4). However, area of grassland fragment or landscape diversity did not affect pollinator richness (Table 3).

Table 3. Degrees of freedom, $F$ - and $P$-values of mixed effects models for 45 and 44 patches nested within 16 and 15 populations of Primula veris in 2000 and 2005, respectively. Patch size, habitat area of calcareous grassland fragments, and landscape diversity (radius $250 \mathrm{~m}$ around centre) went into the model as fixed factors and grassland identity as the random factor. For predicting the number of seeds, pollinator abundance and diversity were included in the model. Patch and habitat size were log10-transformed, pollinator densities, richness and seeds per fruit were square root-transformed, predation rates were arcsine-transformed. For pollinator abundance and richness in 2000 and seed set in 2005, no significant effects were found.

2000:

\begin{tabular}{lcccccc}
\hline & \multicolumn{3}{c}{ Seeds per fruit } & \multicolumn{3}{c}{ Seed predation } \\
& \multicolumn{3}{c}{2000} & \multicolumn{3}{c}{2000} \\
\hline Patch size & d.f. & $F$ & $P$ & d.f. & $F$ & $P$ \\
Calcareous grassland area & 1,28 & 17.60 & $<0.001$ & n.s. & n.s. & n.s. \\
Landscape diversity & n.s. & n.s. & n.s. & 1,14 & 10.70 & 0.006 \\
Pollinator abundance & n.s. & n.s. & n.s. & n.s. & n.s. & n.s. \\
Pollinator richness & n.s. & n.s. & n.s. & & & \\
\hline
\end{tabular}

2005:

\begin{tabular}{lccccccccc}
\hline & \multicolumn{3}{c}{ Pollinator abundance } & \multicolumn{3}{c}{ Pollinator richness } & \multicolumn{3}{c}{ Seed predation } \\
& \multicolumn{3}{c}{2005} & & \multicolumn{2}{c}{2005} & \multicolumn{3}{c}{2005} \\
\hline & d.f. & $F$ & $P$ & d.f. & $F$ & $P$ & d.f. & $F$ & $P$ \\
Patch size & 1,28 & 11.08 & 0.003 & 1,28 & 22.42 & $<0.001$ & n.s. & n.s. & n.s. \\
Calcareous grassland area & 1,12 & 6.49 & 0.026 & n.s. & n.s. & n.s. & 1,13 & 6.71 & 0.022 \\
Landscape diversity & 1,12 & 3.61 & 0.082 & n.s. & n.s. & n.s. & n.s. & n.s. & n.s. \\
\hline
\end{tabular}



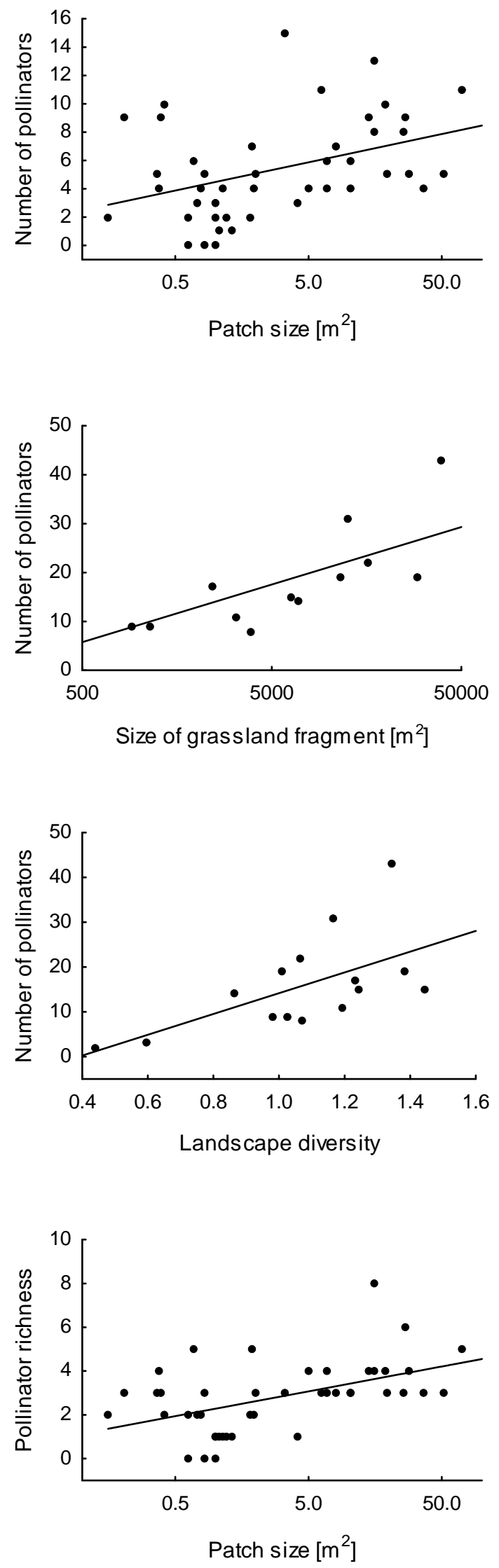

Figure 1. Relation between the pollinator density (number of pollinators observed over 45 minutes on ten inflorescences) and patch size of 44 Primula veris patches in $2005\left(F_{1,28}=11.08\right.$, $P=0.003)$.

Figure 2. Relation between pollinator density and habitat area of 15 calcareous grasslands with Primula veris populations $\left(F_{1,12}=6.49\right.$, $P=0.026)$.

Figure 3. Relation between pollinator density and landscape diversity within a radius of $250 \mathrm{~m}$ around 15 calcareous grasslands with Primula veris populations in $2005 \quad\left(F_{1,12}=3.61\right.$, $P=0.082$ ).

Figure 4. Relation between pollinator species richness and patch size of 44 Primula veris patches in $2005\left(F_{1,28}=22.42, P<0.001\right)$. 


\section{Seed set and pollination limitation}

Average seed set per patch in 2000 ranged from 20.7 to 44.5 seeds per fruit and was significantly influenced by patch size (Table 3). Increasing size of $P$. veris patches led to an increase in seed set (Fig. 5). Flower visitors, however, did not affect the number of seeds per fruit. Looking at the overall seed set in 2000, there was no significant difference between open- and hand-pollinated flowers (paired t-test, $\mathrm{n}=38, P=0.183$ ). However, when comparing different treatments at the three patch size classes, we found a significantly higher seed set in hand- versus open-pollinated flowers in patches smaller than $1 \mathrm{~m}^{2}$ compared to intermediate patches between 1 and $2 \mathrm{~m}^{2}$, or patches larger than $2 \mathrm{~m}^{2}$ (Fig. 6).

Many of the marked Primula plants in 2005 were consumed by herbivorous mammals like rabbits, hares, sheep, or goats. Only a low number of patches $(n=20)$ with adequate sample size (at least 5 fruits of both open- and hand-pollinated plants) remained and no significant model predicting seed set was found in 2005. Comparing open- and handpollinated flowers, a difference in seed set was neither found in all patches (paired t-test, $\mathrm{n}=20, P=0.249)$ nor in patches smaller than $1 \mathrm{~m}^{2}(\mathrm{n}=5, \mathrm{P}=0.264)$.

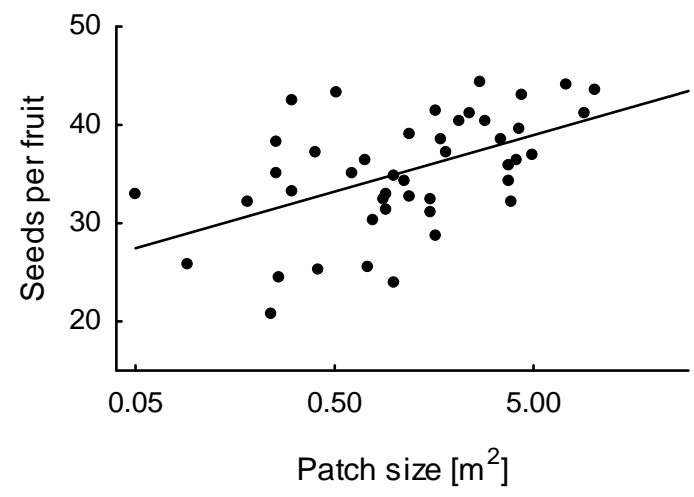

Figure 5. Relation between average number of seeds per fruit and patch size of 45 Primula veris patches in $2000\left(F_{1,28}=17.60, P<0.001\right)$.

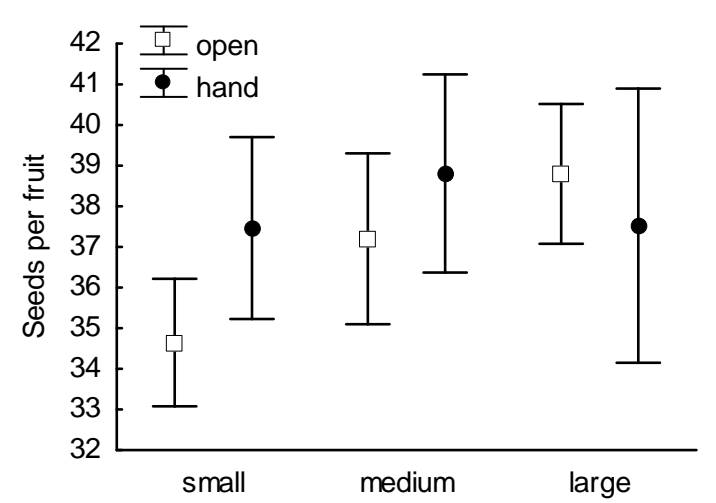

Figure 6. Number of seeds per fruit (mean \pm $95 \%$ confidence intervals) for hand-pollinated flowers versus open-pollinated flowers (patches where at least 5 fruits of each treatment could be harvested). Seed set in small patches $\left(<1 \mathrm{~m}^{2}\right)$ differed significantly (paired t-test, $\mathrm{n}=16$, $P=0.032)$, seed set in medium $\left(1 \mathrm{~m}^{2}-2 \mathrm{~m}^{2}\right.$, $\mathrm{n}=11, P=0.348$. $)$ and large $\left(>2 \mathrm{~m}^{2}, \mathrm{n}=11\right.$, $P=0.567)$ patches did not differ significantly. 


\section{Seed predation}

We observed two, not further determined, species of tortricid moths emerging from predated fruits. Predated fruits were found in 11 out of 16 populations and in 27 out of 45 patches in 2000 . Between $0 \%$ and $87.3 \%$ of collected fruits of open-pollinated flowers were predated per patch by insects. Area of calcareous grassland fragments was the only factor determining the predation rate of $P$. veris fruits (Table 3). Predation rates increased significantly with increasing habitat area (Fig. 7). In 2005, predated fruits were found in 12 out of 15 populations and in 29 out of 44 patches. Predation rates per patch ranged between $0 \%$ and $100 \%$ of collected fruits. Even though the model was not as strong (Table 3), seed predation in 2005 was also positively influenced by fragment area (Fig. 7).

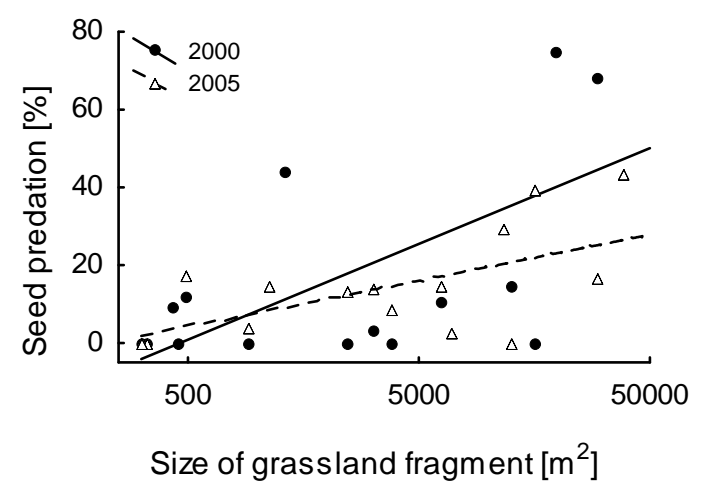

Figure 7. Relation between seed predation rate and habitat area of 16 calcareous grasslands with Primula veris populations in $2000\left(F_{1,14}=10.70\right.$, $P=0.006)$ and 15 calcareous grasslands in 2005 $\left(F_{1,13}=6.71, P=0.022\right)$.

\section{Discussion}

\section{Pollinator abundance and richness}

We found extreme differences in pollinator abundance between the two study years 2000 and 2005. Different weather conditions can not explain these differences because mean temperature, precipitation, and number of sunny days per month were almost equal during flowering time of $P$. veris in both years and also very similar in the preceding winters (Deutscher Wetterdienst, Wetterstation Göttingen). The differences may be due to natural year-to-year fluctuations in pollinator communities (Roubik 2001; Ivey et al. 2003) or due to stronger competition for pollinators with simultaneously flowering plants in 2000 compared to 2005 , but we have no data to prove this hypothesis.

More pollinators per inflorescence were found in large patches of $P$. veris than in small patches. Higher visitation rates (Mustajärvi et al. 2001) and longer residence time (Cresswell and Osborne 2004) of bumble bees in patches with more flowers have been shown 
in experimental populations of a wild plant, Lychnis viscaria, and oilseed rape, respectively. Large patches are more attractive to pollinators because they have a high abundance of pollen and nectar resources to permit sufficient yield and pollinators rewarded on their foraging bouts will stay longer to collect nectar or pollen (Zimmerman 1981). The individual plant may benefit from this attraction of many conspecific flowers by receiving more visits (Sih and Baltus 1987) that will consequently result in higher seed set as could be observed in large patches. Rathcke (1983) proposed that visitation rate increases with increasing floral resources until a threshold is reached where no more pollinators can be attracted. A further increase then leads to decreased visitation rates because individual plants of a patch start to compete for pollinators (Steven et al. 2003). The optimum of P. veris was seemingly not reached in this study with patch sizes of up to $37 \mathrm{~m}^{2}$ because even at this level, visitation rate increased linearly with increasing patch size.

Primula veris plants also received more pollinator visits on larger calcareous grassland habitats than on smaller fragments. Large calcareous grasslands can support large populations of pollinators because they provide high amounts of pollen and nectar and also offer various larval food and nesting resources. Increased habitat area has been shown to enhance the abundance of bees (Aizen and Feinsinger 1994; Steffan-Dewenter 2003) and butterflies (Krauss et al. 2003). In addition to resident pollinators, large calcareous grasslands may further attract pollinators foraging in the surrounding landscape because the size of grassland fragments in our study was highly correlated with the number of total individuals of $P$. veris and large grasslands with a prominent cover of yellow Primula flowers may therefore be easily detected by pollinators with good dispersal abilities like bumble bees (Westphal et al. 2006).

More pollinators were found on sites that were embedded in a diverse landscape matrix within a radius of $250 \mathrm{~m}$ around the calcareous grasslands. When the proportion of semi-natural habitats in the surrounding landscape was increased, bee abundance has been found to increase in canola fields (Morandin et al. 2007) and in experimental patches of Centaurea jacea (Steffan-Dewenter et al. 2001). Butterflies were also shown to correlate with landscape heterogeneity (Weibull et al. 2000). A complex landscape in our study region implies the presence of semi-natural grasslands, fallows, orchard meadows, hedgerows, woodlands, and gardens that provide additional foraging plants and a variety of nesting resources for bee species and other flower visitors (Steffan-Dewenter and Tscharntke 2002). A diverse landscape also includes arable land that provides e.g. larval food resources for syrphid flies with aphidophagous larvae that we also found visiting $P$. veris. The most 
important scale for flower visitors was the $250 \mathrm{~m}$ radius, i.e. the landscape directly adjacent to the calcareous grasslands. This effect may be attributed to the foraging ranges of wild bees, the most abundant flower visitors of $P$. veris, that range from 150 to $400 \mathrm{~m}$ (Gathmann and Tscharntke 2002).

In contrast to previous studies (Aizen and Feinsinger 1994; Krauss et al. 2003; Cane et al. 2006; Öckinger and Smith 2006; Ouin et al. 2006), we found no effects of habitat area on pollinator species richness. However, our study only concerned visitors of $P$. veris, not the entire pollinator community in calcareous grasslands thus purposely neglecting habitat heterogeneity by analysing Primula patches only. Small and large habitat fragments both seem to support the entire spectrum of $P$. veris flower visitors in our study region. This might be due to the fact that even small fragments included large patches and large patches exhibited the highest taxonomic richness of Primula-visiting insects. Large patches offering quantitatively large amounts of energetic rewards are foraged thoroughly by pollinators which increases the probability of also detecting numerous species.

Because $P$. veris flowers in early spring, the spectrum of possible pollinators is relatively low. Mainly bumble bees and large solitary bees like Osmia spp. and Anthophora spp. are foraging at this time (Westrich 1989b). However, we also observed smaller wild bees like halictid bees as well as syrphid flies and beetles, especially Meligethes spp. of considerable numbers. Primula veris is a generalist with respect to its pollinators and might have a reduced risk of pollination failure because the loss of one pollinator can be compensated by another (Waser et al. 1996; Wilcock and Neiland 2002). Still, Aguilar et al. (2006) found that generalist plants are not less affected by fragmentation than specialists. Despite the advantage over specialists of avoiding total extinction over a long time scale, generalists also suffer from pollen limitation, expressed by lower seed set, because overall pollinator abundance is likely to be reduced in small fragments, failing to provide enough flower visits for sufficient pollination.

\section{Seed set and pollination limitation}

We found a strong reduction in seed set with decreasing size of $P$. veris patches. This result supports findings of Kéry et al. (2000) and Brys et al. (2003). The former analysed seed set of $P$. veris populations ranging from 9 to 13,000 individuals and reported the strongest negative effects on reproductive success in populations with less than 200 plant individuals. The populations of our study have been considerably larger. Single $P$. veris patches within these populations, however, ranged from 10 to 1,600 flowering individuals and it was on this patch scale, that we observed area effects on seed set. Our results furthermore suggest that 
reduced seed set in the smallest patches is due to pollen limitation, as the number of seeds per fruit of hand-pollinated flowers was significantly higher than the number of seeds from openpollinated flowers. This pollination deficit could be explained by the observed foraging behaviour; that is pollinators avoid small patches because they lack sufficient rewards to justify the handling effort. Large patches, on the other hand, seem to offer enough pollen and nectar to receive adequate numbers of pollinator visits.

A direct effect between observed pollinator abundance on the number of seeds per fruit, as was shown for Primula sieboldii (Matsumura and Washitani 2000), was not evident in our study. We therefore argue that several confounding patch size related factors conceal the relationship between observed visitation rate and seed set: First, the probability that $P$. veris' generalist pollinators are mostly laden with conspecific pollen is higher in large patches (Waites and Ágren 2004), whereas generalist pollinators foraging in small patches possibly carry many different pollen types (Talavera et al. 2001) that may then clog the stigma and reduce seed set (Wilcock and Neiland 2002). Second, an unequal ratio of pin vs. thrum plants may occur in small patches. In patches with less than 10 flowering individuals it has been observed that all plants belong to the same style-type (Kéry et al. 2003). Because P. veris individuals can only be fertilized by pollen from the opposite morph type, even high abundances of pollinators could not induce seed set in these patches, unless they bring pollen from neighbouring, opposite morph-types.

A reduction in produced seeds may lead to decreased genetic diversity in small patches and compromise the ability of a plant to adapt to a changing environment. This may have detrimental effects on the long-term survival of plants and may increase extinction rates in small patches (Fischer and Stöcklin 1997). Because P. veris has a life-span of 50 years (Inghe and Tamm 1988) and fragmentation has only become a problem in recent decades, increased rates of extinctions of small populations might be observed in the future.

\section{Seed predation}

In addition to produced seeds per fruit, we analysed the predation rates of $P$. veris in dependence of area and landscape effects to further quantify plant reproductive success. In a Finish study on pre-dispersal seed set in P. veris, the seed predators were a plume moth (Pterophoridae) and a tortricid moth (Tortricidae) (Leimu et al. 2002). We observed two species of tortricid moths emerging from predated fruits.

Despite the often seen spatiotemporal variation in seed predation rates (Ehrlén 1996; Leimu et al. 2002; Pías et al. 2007), we could show that the predation rate of $P$. veris was consistently influenced by the area of calcareous grasslands over both study years. In 2000 
and 2005, we found significantly more predated fruits on larger fragments. Primula veris, alluring pollinators with showy yellow flowers covering entire grasslands, is attracting at the same time pre-dispersal seed predators (Ehrlén 1996; Brody and Mitchell 1997). However, seed predation may not necessarily lead to a reduced overall plant fitness of $P$. veris (Leimu et al. 2002). Even though highly predated, large P. veris patches in large calcareous grasslands might not decrease in population growth because increased seed set may counterbalance the effects of pre-dispersal seed predation. And small P. veris patches in small habitat fragments, although disadvantaged considering visitation rates and seed set, are untroubled by seed predation that would further reduce their reproductive output. On the other hand, small $P$. veris patches in large grassland fragments that have reduced seed set and additionally suffer from increased seed predation are most likely to experience reduced plant fitness over time. Benefiting from increased seed set and decreased predation rates, large $P$. veris patches in small fragments should therefore experience a positive growth rate. However, the predicted fitness increase of $P$. veris in these large patches may be limited by the actual size of the calcareous grassland fragment or by the availability of microsites, that are suitable for germination and the survival of seedlings (Eriksson and Ehrlén 1992). Further research monitoring the long-time plant fitness of $P$. veris in dependence of reproductive success and habitat quality will be necessary.

\section{Spatial scales}

We can conclude that pollinators were most abundant in large patches of $P$. veris, on large calcareous grassland fragments and in diverse landscapes, thereby reacting to all tested factors of agricultural land use change. Seed predation rate responded to the area of calcareous grassland fragments whereas seed set depended on patch size. Pollination limitation was found in patches smaller than $1 \mathrm{~m}^{2}$. Our results make evident that plant-insect interactions should be analysed at different spatial scales in order to make predictions about the consequences of agricultural land use change for mutualistic and antagonistic relationships with a plant species. If we had focused on population level only, we would have overlooked the effect of patch size on pollinator diversity and seed set, and falsely concluded that there is no pollination limitation. If we had, on the other hand, focused on patch level only, we would not have seen differential rates of seed predation due to effects of fragment size.

Considering the effects of different spatial scales on flower visitation, seed set, and seed predation, conservation efforts should also focus on patch, population, and landscape levels to preserve plant-insect interactions and ecosystem functioning. To prevent the loss of 
the rare distylous perennial $P$. veris, management decisions have to consider foremost the preservation of its habitat, calcareous grasslands. To ensure adequate number of conspecifics, extensive management on this biotope is necessary to prevent calcareous grasslands from succession reducing $P$. veris populations to small patches. Plant-pollinator interactions will further benefit from a well balanced matrix of semi-natural and agricultural landscape features that prevents pollen limitation of self-incompatible rare plants in calcareous grasslands. 
CHAPTER

5

\section{PATCH AND LANDSCAPE EFFECTS}

ON POLLINATOR DIVERSITY AND SEED SET OF HIPPOCREPIS COMOSA

IN AN AGRICULTURAL LANDSCAPE

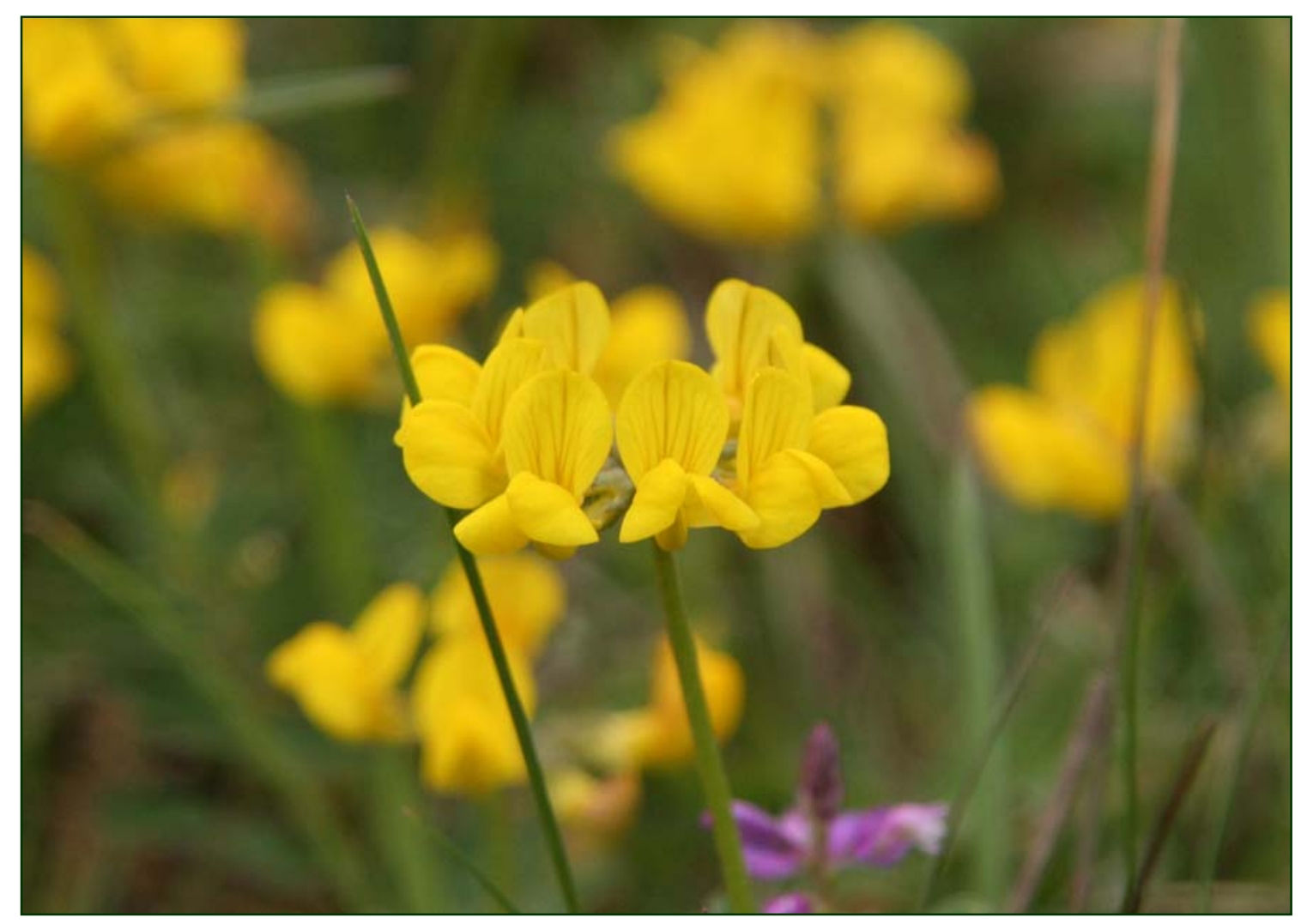




\section{Abstract}

Agricultural land use intensification has caused a considerable decline of once common semi-natural habitats leaving only small and isolated habitat remnants within a homogeneous landscape matrix. Populations of flowering plants in these remaining habitat fragments are also declining and can not offer sufficient resources for potential pollinators. The loss of pollinators and consequential pollination limitation is especially severe for obligately out-crossing plant species. In this study, pollination and reproductive success of Hippocrepis comosa was examined. Hippocrepis comosa is a self-incompatible, declining plant species occurring in fragmented remnants of semi-natural calcareous grassland habitats in an agricultural landscape in Southern Lower Saxony, Germany. Plant-pollinator interactions were analysed in small, medium, and large plant patches in 15 differently sized calcareous grassland fragments surrounded by landscape matrices of differing complexity. Flower visitors were observed during three 15-minute observations, pollen supplementation experiments were performed to test for pollination limitation, and fruits from the plant patches were collected to calculate seed set. Hippocrepis comosa showed evidence of pollination limitation because hand-pollinated flowers set more seeds per fruit than open-pollinated flowers and seed set was strongly reduced by decreased visitation rates. Pollinators were most abundant in large patches and in diverse landscapes. Visitation rate was not affected by patch size. Hence, in order to maintain plant-pollinator interactions in an agricultural landscape, conservation efforts should include the preservation of calcareous grasslands that can support sufficiently large patches of a plant species and offer ample rewards for pollinators and the establishment of a diverse agricultural landscape around the semi-natural habitats that will further enhance pollinator abundance.

\section{Zusammenfassung}

Die Intensivierung der Landwirtschaft führte während der letzten Jahrzehnte zu einer drastischen Abnahme von naturnahen Lebensräumen, so dass nur kleine, isolierte Habitatfragmente in einer monotonen Agrarlandschaft verbleiben. Die Pflanzenpopulationen, die auf diese naturnahen Lebensräume angewiesen sind, schwinden ebenfalls und können potentiellen Bestäubern nicht genug Nahrungsressourcen bieten. Der Verlust der Bestäuber und die daraus resultierende Bestäubungslimitierung hat für obligat fremdbestäubte Pflanzenarten besonders schwerwiegende Konsequenzen. In dieser Studie wird die Bestäubung und der Reproduktionserfolg von Hippocrepis comosa, einer selbst- 
inkompatiblen, bedrohten Pflanzenart, die auf Kalkmagerrasen in der Agrarlandschaft in der Region Südniedersachsen vorkommt, untersucht. Pflanze-Bestäuber-Interaktionen wurden auf kleinen, mittleren und großen Patches auf 15 verschieden großen Kalkmagerrasen, eingebettet in unterschiedlich diversen Landschaften, analysiert. Blütenbesucher wurden während fünfzehnminütiger Beobachtungen aufgenommen, Bestäubungsexperimente zur Bestäubungslimitierung durchgeführt und Früchte entnommen, um den Samenansatz zu messen. Es wurden deutliche Hinweise für eine Bestäubungslimitierung bei Hippocrepis comosa gefunden, da zusätzlich handbestäubte Blüten mehr Samen ausbildeten als unbehandelte Blüten und der Samenansatz mit abnehmender Besuchsrate sank. Die Abundanz der Bestäuber war auf großen Patches und in diversen Landschaften erhöht, wobei sich die Besucherraten auf kleinen, mittleren und großen Patches nicht unterschieden. Um intakte Pflanze-Bestäuber-Interaktionen in einer Agrarlandschaft zu bewahren, sollten einerseits Kalkmagerrasen, die große Pflanzenpopulationen beherbergen können, erhalten werden und andererseits eine diverse Landschaftsstruktur um die naturnahen Lebensräume geschaffen werden.

Key words: calcareous grasslands - foraging behaviour - habitat fragmentation - landscape diversity - patch size - pollination limitation - reproductive success - self-incompatible visitation rate

\section{Introduction}

Agricultural land use intensification is considered to be one of the major causes of the disruption of plant and pollinator communities on semi-natural habitats and hence adversely affects the ecosystem service of pollination (Kearns et al. 1998). Habitat destruction and degradation leaves only fragments of once more common semi-natural habitats containing small and isolated plant populations in a matrix of unsuitable, structurally poor landscapes (Vitousek 1994; Fischer and Stöcklin 1997). Small plant populations are then further threatened by stochastic factors such as the loss of genetic variation due to inbreeding, or demographic fluctuations that will compromise the ability of a plant to buffer environmental degradation (Menges 1991) and impede its long-term survival in fragmented habitats. Calcareous grasslands are semi-natural habitats that harbour many rare and threatened plant species and are among the habitats with the highest taxonomic diversity in Western Europe (Ellenberg 1996). They developed centuries ago by land use practices like sheep- and goatherding (Poschlod and WallisDeVries 2002). In recent decades, however, as traditional land 
use practices became uneconomical, many calcareous grasslands were replaced by intensive agricultural land use types or abandoned to natural succession (Poschlod and WallisDeVries 2002).

Fragmentation of plant populations in semi-natural habitats like calcareous grasslands may have adverse effects on pollinator communities on different spatial scales: 1) At the patch scale, small plant patches with reduced floral availability do not offer sufficient rewards to be attractive to flower visitors. Pollinators may express different foraging behaviour e.g. reduced visitation rates (Sih and Baltus 1987). 2) At the habitat scale, small and isolated calcareous grassland habitats with reduced habitat heterogeneity and diminished food and nesting resources can not maintain viable populations of pollinators. Consequently, reduced pollinator abundance and species richness are often seen in small, isolated habitats (e.g. Aizen and Feinsinger 1994; Krauss et al. 2003; Cane et al. 2006; Ouin et al. 2006). 3) At the landscape scale, the landscape context in which fragmented plant populations are embedded, further influences the composition of insect communities (Tscharntke and Brandl 2004). The matrix structure is especially important for mobile species such as bees that often forage and nest among different habitat types. An unsuitable matrix does not allow for multi-habitat use and may impair movement of pollinators across the landscape (Ricketts 2001).

Low numbers of available pollinators and decreased visitation rates result in a failure of pollen dispersal (Wilcock and Neiland 2002) adversely affecting seed set (Burd 1994; Ashman et al. 2004). Pollination limitation is especially detrimental in obligately out-crossing plants such as Hippocrepis comosa, where self-fertilisation is impeded by proterandry. Hippocrepis comosa is pollinated by generalist pollinators such as honey bees and bumble bees that may carry pollen of different plant species (Talavera et al. 2001) potentially causing a clogging of the stigma with heterospecific pollen in patches with few conspecific flowers. Pollination limitation can be experimentally demonstrated either by pollination supplementation experiments, comparing seed set of hand pollinated versus open pollinated flowers or by relating observations of flower-visitation to the obtained seed set (Dafni et al. 2005).

In this study, local and landscape scale effects on the pollinator community of $H$. comosa are linked with their ecosystem function, i.e. pollination, and the resulting reproductive success, by:

1. determining the effects of agricultural land use change on pollinator communities in patches of the rare self-incompatible herb $H$. comosa on its calcareous grassland habitat, 
2. analysing if foraging behaviour changes with varying patch size, habitat area, or landscape diversity, and

3. testing for pollination limitation with pollen supplementation experiments and by relating seed set to observed visitation by pollinators.

The hypotheses of this study are that $H$. comosa is pollination limited and will have reduced seed set in patches receiving fewer flower visits; that decreased patch size, area of calcareous grassland fragments and landscape diversity will reduce density and species richness of pollinators visiting Hippocrepis comosa, and that their visitation rates will be higher in large patches.

\section{Materials and Methods}

Study species and its habitat

Hippocrepis comosa L. (Fabaceae) is a perennial herb occurring on south- to southwest-facing slopes, on shallow, calcareous soils in Central and Southern Europe (Fearn 1973). The study area in Southern Lower Saxony represents the species' north-eastern boundary analogous to the distribution of calcareous soils. The 5-30 $\mathrm{cm}$ tall herb has imparipinnate leaves and bright yellow flowers arranged in heads of 5-8 on a long peduncle (Voggesberger 1992). In Germany, H. comosa flowers from the end of May until the beginning of July (Hennenberg and Bruelheide 2003). Hippocrepis comosa is allogamous and entomophilous; selfing is prohibited by proterandry. Pollination is effected by a pump mechanism where heavy flower visitors like Apis mellifera, Bombus spp., Osmia spp., or Megachile spp. cause the flower to press out pollen from the tip of the carina (Fearn 1973). Each pollinated flower develops into a 10-30 mm pod that breaks up into 3-6 segments after ripening, each containing one seed. The bent shape of the segments led to H. comosa's common name, horseshoe vetch. Seeds are probably distributed zoochorously in the hooves of sheep (Fischer et al. 1996) grazing on calcareous grasslands. Calcareous grasslands, the habitat of $H$. comosa, occur on nutrient-poor, shallow soils of calcareous rock with low water capacity. They belong to the phytosociological association Gentiano-Koelerietum and contain a very species-rich flora with xero- and thermophilic plants (Ellenberg 1996). Because of the fragmentation of its calcareous grassland habitat, $H$. comosa is declining and included in the Red Data Book as “vulnerable” (Garve 1994).

Study region and study design

The calcareous grassland study sites are located around the city of Göttingen in 
southern Lower Saxony, Germany. This region is characterized by intensively managed agricultural areas and calcareous grasslands are highly fragmented covering only about $0.3 \%$ of the total study area of $1,944 \mathrm{~km}^{2}$.

In 2000 and 2005, 15 calcareous grasslands with $H$. comosa populations were selected lying within a surrounding matrix of differing landscape diversity. Using Geographic Information Systems (GIS, ARC/View 3.2 ESRI Geoinformatik, Hannover, Germany) the percent land cover of different habitat types (arable land, forest, grassland, built-up area, garden land, hedgerows, calcareous grasslands, orchard meadows, fen, plantations, and other habitats) was measured and landscape diversity $\left(H^{\prime}\right)$ was calculated at each of twelve different spatial scales ranging from 250 to 3000 m radius around the centre of the calcareous grassland using the Shannon-Wiener index (Krebs 1989). Because landscape diversity of these twelve different landscape scales correlated significantly with each other, only the most significant landscape scale (750 m) was used for further analysis.

The area of the calcareous grassland fragments was measured in 2000 with a differential GPS GEOmeter 12L (GEOsat GmbH, Wuppertal, Germany) and ranged from $314-51,395 \mathrm{~m}^{2}$. Of the 15 populations studied in each year, ten grasslands were common to both years resulting in 20 different sites over both years.

Within each $H$. comosa population on each calcareous grassland fragment, 2-4 patches of differing size classes were chosen for a total of 42 patches in 2000 ranging from 0.01 $140 \mathrm{~m}^{2}$ per patch and 54 patches in 2005 ranging from $0.17-15.4 \mathrm{~m}^{2}$. This way, different patch sizes could be analysed independent of grassland size.

\section{Flower visitation observation}

To determine the density and taxonomic richness of pollinators, flower visitation observations in 54 patches of $H$. comosa were performed three times from May $5^{\text {th }}$ to June $18^{\text {th }}$ 2005. Due to differences in the used methodology, observations from 2000 are not comparable to those from 2005, and were therefore only used for calculation of visitation rates in the context of experimental pollination treatments (see below).

Observations took place once during the start of the flowering period, once at the peak of flowering and once at the end of flowering, between 0930 and 1730 hours on sunny days with little wind and at least $16{ }^{\circ} \mathrm{C}$. All study sites were sampled in a randomized sequence and at different times during the day. At each observation period, a $0.4 \times 0.4 \mathrm{~m}$ square was randomly placed inside each patch. The number of inflorescences within the observation unit were recorded and observed for 15 minutes. All visitors were noted and identified on the wing to the lowest taxonomic level possible. Noted were also the number of inflorescences and the 
number of single flowers visited by each pollinator. The visitation rate was calculated by dividing the number of visited inflorescences by the number of inflorescences present in the observation unit.

\section{Pollination experiments}

In 2000, seed set was determined in 42 patches of Hippocrepis comosa by randomly marking 15 inflorescences per patch when flower buds first emerged and collecting these open-pollinated pods in August when the seeds had ripened. To assess pollination limitation, five additional inflorescences in each patch were randomly chosen, marked, and crosspollinated by hand with pollen from at least two $H$. comosa plants of a neighbouring patch and also collected after ripening. As a measure of reproductive success, the number of seeds per inflorescence for open- and for hand-pollinated inflorescences was counted. In order to relate reproductive success to visitation rate, the number of visited inflorescences was recorded during three 15 minute observation periods from May $6^{\text {th }}$ to June $24^{\text {th }} 2000$. To calculate visitation rate, the number of visited inflorescences was divided by the total inflorescences available per patch. For eight patches larger than $4 \mathrm{~m}^{2}$, the number of inflorescences was counted and flower visitation was observed on a 2 x 2 m square.

\section{Statistical analysis}

For the analysis of flower visitation, data were pooled over 45 minutes; reproductive data were averaged per patch. The three predictor variables patch size, area of calcareous grasslands, and landscape diversity were neither correlated in 2000 (patch - grassland area: $\mathrm{n}=42$, Pearson- $r=0.002, P=0.806$; grassland area - landscape: $\mathrm{n}=15$, Pearson- $r=0.056$, $P=0.395$; patch - landscape: $\mathrm{n}=42$, Pearson- $r=0.012, P=0.488$ ) nor in 2005 (patch grassland area: $\mathrm{n}=54$, Pearson- $r=0.001, P=0.854$; grassland area - landscape: $\mathrm{n}=15$, Pearson- $r=0.011, P=0.705$; patch - landscape: $\mathrm{n}=54$, Pearson- $r=0.028, P=0.229$ ). The statistical analyses of the data were carried out using R, Version 2.4.1 (R Development Core Team 2006). All response variables were tested for meeting the assumptions of normality and homoscedasticity. Pollinator densities, richness, and seeds per inflorescence were square roottransformed; visitation rate was arcsine-transformed for analyses. The predictor variables, patch size and area of calcareous grasslands, were log10-transformed for analyses.

To analyse flower visitation and seed set in relation to the different spatial scales of patch, habitat, and landscape, a nested design was applied with patch factors, i.e. patch size nested within site factors, i.e. grassland area and landscape diversity. Linear mixed effects models (Pinheiro and Bates 2000) were used, fitted by maximum likelihood in the nlme 
package (Version 3.1-79) of R 2.4.1. Fixed effects terms were added sequentially, and models differing in their fixed effects structures were compared using F-tests and Akaike information criterion (AIC, Burnham and Anderson 2002). The minimal adequate model was the one with the lowest AIC. The order of fixed effects terms was patch size, area of calcareous grassland fragments, and landscape diversity, while site identity was treated as random block factor. In order to predict the number of seeds per inflorescence, visitation rate was included in the model as a further fixed factor. A paired t-test was used to compare seed set of hand- versus open-pollinated inflorescences.

\section{Results}

Effects of patch size, habitat area, and landscape diversity on flower visitors

Table 1. Number of individuals and visited inflorescences for visitors of Hippocrepis comosa L., observed over 45 min on 54 patches in 2005. Bombus terrestris agg. is a group of B. terrrestris and B. lucorum, which are difficult to distinguish in the field.

\begin{tabular}{lcc}
\hline & $\begin{array}{c}\text { Number of } \\
\text { flower visitors }\end{array}$ & $\begin{array}{c}\text { Visited } \\
\text { inflorescences }\end{array}$ \\
\hline Hymenoptera & 3 & 7 \\
Andrena spec. & 235 & 1683 \\
Apis mellifera & 84 & 650 \\
Bombus lapidarius & 8 & 67 \\
Bombus pascuorum & 3 & 6 \\
Bombus terrestris agg. & 19 & 26 \\
Halictus/Lasioglossum spp. & 1 & 2 \\
Megachile spec. & 2 & 3 \\
Osmia aurulenta & 47 & 163 \\
Osmia bicolor & 5 & 20 \\
Osmia rufa & 1 & 4 \\
Osmia spec. & 1 & 1 \\
Psithyrus rupestris & 2 & 3 \\
Psithyrus spec. & & \\
Lepidoptera & 15 & 19 \\
Hesperiidae & 2 & 2 \\
Lycaenidae & 1 & 5 \\
Noctuidae & & \\
Diptera & 1 & 1 \\
Syrphus spec. & 2 & 2 \\
Bibionidae & 2 & 5 \\
Sarcophagidae & 1 & \\
Coleoptera & 1 & \\
Meligethes spec. & 436 & \\
Oedemeridae & & \\
Total & & \\
\hline
\end{tabular}


In 2005, 436 individuals from 21 different taxa were observed in a total of 2,430 minutes in the $0.4 \times 0.4 \mathrm{~m} \mathrm{H}$. comosa observation plots (Table 1). Apis mellifera, Bombus lapidarius, and Osmia bicolor were the most common flower visitors. The observed pollinators visited a total of 2,674 H. comosa inflorescences in the observation plot (Table 1 ).

Table 2. Degrees of freedom and F-values of mixed effects models for 42 and 54 Hippocrepis comosa L. patches nested within 15 different populations in calcareous grassland fragments in 2000 and 2005, respectively. Patch size, habitat area of calcareous grassland fragments, and landscape diversity (radius $750 \mathrm{~m}$ around centre) went into the model as fixed factors and grassland identity as the random factor. For predicting the number of seeds, visitation rate was included in the model as a fixed factor. Patch and habitat size were log10-transformed, pollinator density, richness, and seeds per inflorescence were square root-transformed, and visitation rate was arcsine-transformed.

\begin{tabular}{|c|c|c|c|c|c|c|c|c|}
\hline & \multicolumn{2}{|c|}{$\begin{array}{l}\text { Pollinator density } \\
\qquad 2005\end{array}$} & \multicolumn{2}{|c|}{$\begin{array}{c}\text { Species richness } \\
2005\end{array}$} & \multicolumn{2}{|c|}{$\begin{array}{l}\text { Seed set } \\
2000\end{array}$} & \multicolumn{2}{|c|}{$\begin{array}{c}\text { Visitation rate } \\
2000\end{array}$} \\
\hline & d.f. & $F$ & d.f. & $F$ & d.f. & $F$ & d.f. & $F$ \\
\hline Patch size & 1,38 & $185.3^{* * *}$ & 1,38 & $38.52 * * *$ & 1,25 & $3.11^{(*)}$ & n.s. & n.s. \\
\hline Calc. grassland area & n.s. & n.s. & n.s. & n.s. & n.s. & n.s. & n.s. & n.s. \\
\hline Landscape diversity & 1,13 & $8.76^{*}$ & n.s. & n.s. & n.s. & n.s. & 1,12 & $6.48^{*}$ \\
\hline Visitation rate & & & & & 1,25 & $6.77 *$ & & \\
\hline
\end{tabular}

Patch size strongly influenced the abundance and the richness of pollinators (Table 2). The number of pollinators that visited Hippocrepis comosa patches increased significantly with increasing patch size (Fig. 1). An increase in patch size also led to an elevated taxonomic richness (Fig. 2). The area of calcareous grassland fragments was not a significant factor in the model predicting pollinator abundance (Table 2). Pollinator abundance was influenced by landscape diversity within a $750 \mathrm{~m}$ radius around the centre of the calcareous grassland (Table 2). With increasing landscape heterogeneity, the abundance of pollinators increased (Fig. 3). An increasing rate of visited inflorescences to available inflorescences was not found on larger patches in 2005 (Pearson- $\mathrm{r}=-0.15, \mathrm{n}=54, P=0.290$ ), indicating that the individual inflorescence did not benefit from increased pollinator density in larger patches. 


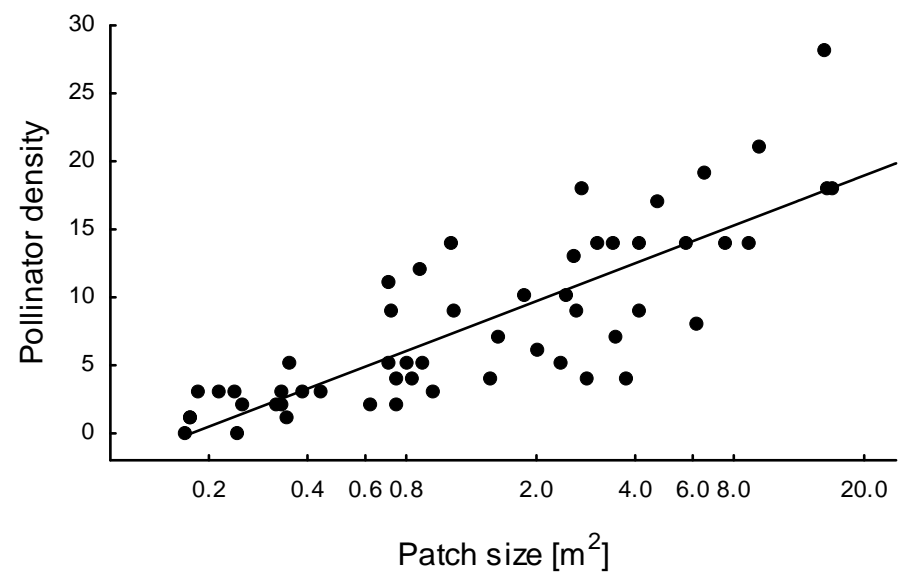

Figure 1. Relationship between number of pollinators and Hippocrepis comosa L. patch size of 54 patches in 2005 $\left(F_{1,38}=185.30, P<0.001\right)$.

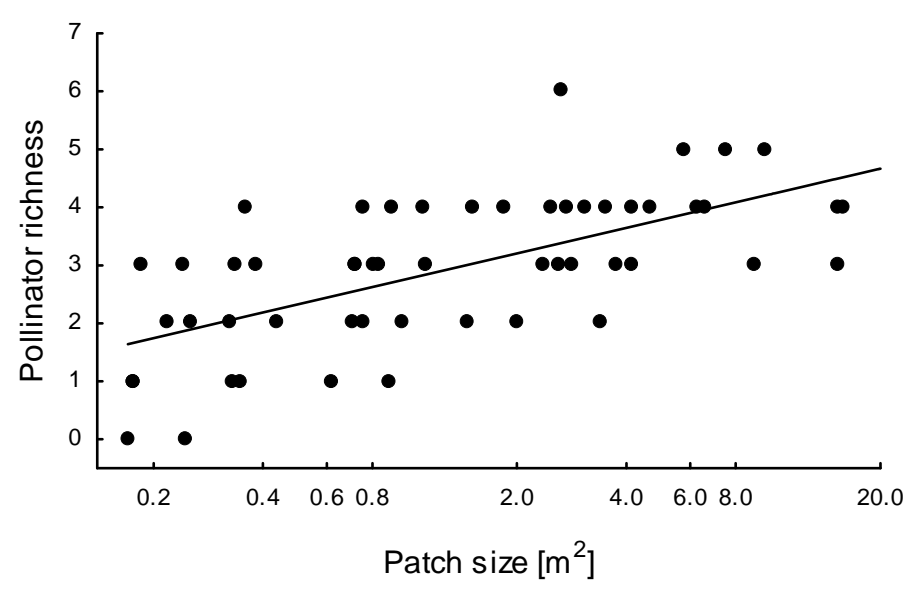

Figure 2. Relationship between taxonomic richness of pollinators and patch size in 54 patches of Hippocrepis comosa L. in $2005 \quad\left(F_{1,38}=38.52\right.$, $P<0.001)$.

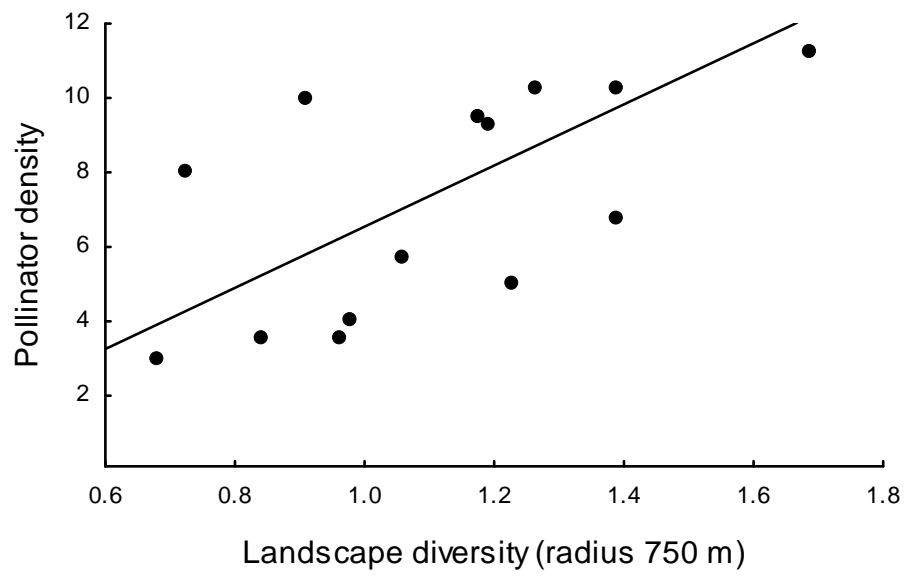

Figure 3. Relationship between average number of pollinators per Hippocrepis comosa patch and landscape diversity within a $750 \mathrm{~m}$ radius around 15 calcareous grasslands in 2005 $\left(F_{1,13}=8.76, P=0.011\right)$.

\section{Pollination of Hippocrepis comosa}

There was a significant difference between open- and hand-pollinated flowers (paired t-test, $\mathrm{n}=42, P=0.034$, Fig. 4 ) indicating that $H$. comosa is pollination limited. The mean number of seeds per inflorescence was $5.79( \pm 0.57)$ for open-, and $7.00( \pm 0.70)$ for handpollinated inflorescences. Average seed set per patch ranged from 0.13 to 16.6 seeds per inflorescence and was significantly affected by visitation rate (Table 2). When a higher 
percentage of $H$. comosa inflorescences was visited by pollinators during the flowering period, more seeds were developed per inflorescence (Fig. 5) further supporting the evidence of pollination limitation of $H$. comosa. Seed set was also marginally increased by patch size (Table 2).

The visitation rate of $H$. comosa inflorescences in 2000 ranged from $0 \%$ to $98.2 \%$; on average $35.1 \%$ inflorescences per patch were visited by pollinators. When analysing the visitation rate in $H$. comosa patches, no increased percentages of visited inflorescences in large patches were found, but a significant effect of landscape diversity on a radius of $750 \mathrm{~m}$ around the Hippocrepis population (Table 2). With increasing landscape diversity, the percentage of visited inflorescences increased. In contrast to expectations no effects of calcareous grassland area or patch size were found.
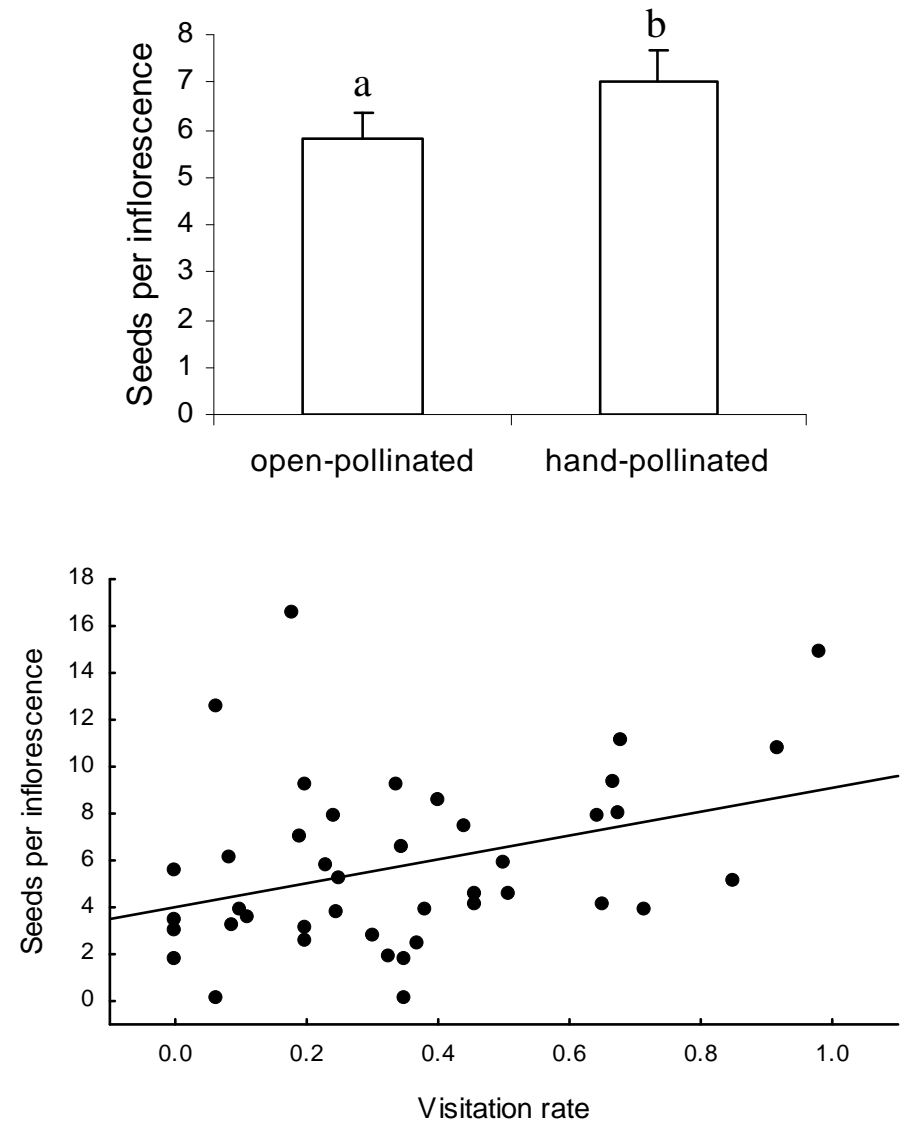

Figure 4. Mean number of seeds per inflorescence ( + standard errors) of open versus hand pollinated treatments in 42 patches of Hippocrepis comosa L. in 2000 (paired t-test, $P=0.034$ ).

Figure 5. Relationship between number of seeds per inflorescence and visitation rate (visited / available inflorescences) on 42 patches of Hippocrepis comosa L. in $2000\left(F_{1,25}=6.77, P=0.015\right)$.

\section{Discussion}

This study gives strong evidence for pollination limitation of Hippocrepis comosa in fragmented calcareous grasslands. First, hand-pollinated inflorescences yielded more seeds than open-pollinated inflorescences. Second, seed set was significantly increased by an 
increased visitation rate of the available inflorescences. This concurs with findings that selfincompatible species are often threatened by pollination limitation in fragmented habitats (Aguilar et al. 2006). Because self-pollination in Hippocrepis is impeded by proterandry where pollen of a flower is released before the stigma is receptive, out-crossing by insect vectors is obligatory for fertilisation in our study system.

Pollinator limitation in self-incompatible plant species may occur because of the pollinator loss due to habitat disruption or fragmentation (Wilcock and Neiland 2002). Small, isolated populations often fail to support sufficient densities of pollinator communities leading to the disruption of plant-pollinator interactions in fragmented habitats (Kearns et al. 1998). Unlike Wolf and Harrison (2001), who found more pollinators and higher fruit production in the Morning Glory Calystegia collina in large compared to small serpentine outcrop habitats, a significant effect of habitat area on pollinator abundance or seed set could not be shown. However, data of this study, in contrast to almost all other related studies, allowed to differentiate between the patch (or subpopulation) and habitat (or population) level. Thus hidden patch-scale effects could be detected that might have been assigned to population size in other studies. This study indeed revealed a positive effect of patch size on pollinator abundance, taxonomic richness, and seed set.

Large patches with a high amount of conspecific plants offer sufficient rewards for flower visitors and attract a high number and diversity of pollinators (Rathcke 1983; Sih and Baltus 1987). Ideally for an individual plant, the higher abundance of pollinators should translate into higher visitation rates, that is an increased percentage of visited inflorescences of all inflorescences present, avoiding competition between plants (Waites and Agren 2004). For $H$. comosa, increased patch size could not increase the visitation rate to individual inflorescences. Hence, the probability of a single inflorescence to receive a pollinator visit remained constant over patches of all sizes. Large patches seemed to offer more flowers than the local pollinator community can visit thereby counterbalancing the benefit of mutual attraction of many conspecifics. Pollinators have been shown to visit proportionally less flowers in large patches because searching for unvisited and hence not already depleted flowers is easier in patches with only a few flowers compared to very large patches (Goulson 2000).

Even though visitation rates were not elevated in large patches, a marginal increase of seed set with increasing patch size was found. Jennersten and Nilsson (1993) attribute effects like these to the possibility that individual pollinators may carry and deposit more conspecific pollen while foraging in large patches compared to small ones. Many insect pollinators 
concentrate on one or a few particular plant species that they visit in a given bout (Goulson et al. 1997; Goulson and Wright 1998; Gegear and Laverty 2005) because floral constancy reduces handling time. Small patches may not contain enough resources to allow for floral constancy, so pollinators might switch to different species when few target plants are available (Kunin 1993). Hippocrepis comosa is usually present in high numbers in calcareous grasslands, but in 2000, another yellow-flowering Fabaceae, Lotus corniculatus, was also abundant. Apis mellifera, Bombus lapidarius, and Osmia bicolor, the main pollinators of Hippocrepis comosa, are polylectic, using many plant families as pollen or nectar sources (Westrich 1989a). As many of these pollinators were observed visiting L. corniculatus after leaving a $H$. comosa patch (personal observation), Lotus might constitute a strong competitor for pollination services on calcareous grasslands. Generalist pollinators carrying different pollen types when foraging in small patches (Talavera et al. 2001) may on the one hand cause a clogging of the stigma with heterospecific pollen (Wilcock and Neiland 2002) and on the other hand lose conspecific pollen to other plant species. Reduced amounts of conspecific pollen on the stigma then prevent adequate fertilization and reduce seed set in small populations.

Visitation rate and pollinator density on $H$. comosa patches were significantly elevated by an increase in landscape diversity around the calcareous grasslands within a radius of $750 \mathrm{~m}$. Effects of landscape context on pollinators in an agricultural landscape have been shown for bees (Steffan-Dewenter et al. 2002; Morandin et al. 2007), butterflies (Weibull et al. 2000), and hoverflies (Kleijn and van Langevelde 2006). A complex landscape in the study region of an agricultural landscape in Southern Lower Saxony offers semi-natural grasslands, fallows, orchard meadows, hedgerows, forest, and gardens thereby providing additional foraging plants and a variety of nesting resources for bee species and other flower visitors (Steffan-Dewenter and Tscharntke 2002). This allows for the conservation of large pollinator populations in the region and for the movement of mobile pollinators among different foraging and nesting sites (Ricketts 2001). The spatial scale of $750 \mathrm{~m}$ is well within the foraging ranges of the large $H$. comosa pollinators; Apis mellifera and Bombus lapidarius (Westphal et al. 2006, Steffan-Dewenter and Kuhn 2003). The solitary bee pollinator Osmia bicolor should also be able to forage within this radius as foraging ranges for the similar sized Osmia rufa are given to be $600 \mathrm{~m}$ (Gathmann and Tscharntke 2002).

In order to implement conservation strategies that aim at preserving ecosystem functions such as the pollination of a self-incompatible declining plant species, one has to assess the spatial scales on which plant-pollinator interactions react to agricultural land use 
change. This study could show that patch size and landscape diversity are important factors determining pollinator communities of the pollination-limited $H$. comosa populations in calcareous grasslands: Patch size increases pollinator density and taxonomic richness and landscape diversity also increases the number of pollinators. $H$. comosa is pollination-limited and seed set is increased with a higher visitation rate and in larger patches that do not receive more visits per plant, but possibly higher amounts of conspecific pollen per visit. 


\section{REFERENCES}

Aguilar, R., Ashworth, L., Galetto, L. \& Aizen, M.A. (2006) Plant reproductive susceptibility to habitat fragmentation: review and synthesis through a meta-analysis. Ecology Letters, 9, 968-980.

Aizen, M.A. \& Feinsinger, P. (1994) Habitat fragmentation, native insect pollinators, and feral honey-bees in Argentine Chaco Serrrano. Ecological Applications, 4, 378-392.

Amiet, F., Herrmann, M., Müller, A. \& Neumeyer, R. (2001) Fauna Helvetica 6 - Apidae 3 Halictus, Lasioglossum. Schweizerische Entomologische Gesellschaft, Neuchâtel.

Amiet, F., Müller, A. \& Neumeyer, R. (1999) Fauna Helvetica 4 - Apidae 2 - Colletes, Dufourea, Hylaeus, Nomia, Nomioides, Rhophitoides, Rophites, Sphecodes, Systropha. Schweizerische Entomologische Gesellschaft, Neuchâtel.

Andren, H. (1994) Effects of habitat fragmentation on birds and mammals in landscapes with different proportions of suitable habitat - a review. Oikos, 71, 355-366.

Ashman, T.L., Knight, T.M., Steets, J.A., Amarasekare, P., Burd, M., Campbell, D.R., Dudash, M.R., Johnston, M.O., Mazer, S.J., Mitchell, R.J., Morgan, M.T. \& Wilson, W.G. (2004) Pollen limitation of plant reproduction: Ecological and evolutionary causes and consequences. Ecology, 85, 2408-2421.

Bergman, K.O., Askling, J., Ekberg, O., Ignell, H., Wahlman, H. \& Milberg, P. (2004) Landscape effects on butterfly assemblages in an agricultural region. Ecography, 27, 619628.

Biesmeijer, J.C., Roberts, S.P.M., Reemer, M., Ohlemuller, R., Edwards, M., Peeters, T., Schaffers, A.P., Potts, S.G., Kleukers, R., Thomas, C.D., Settele, J. \& Kunin, W.E. (2006) Parallel declines in pollinators and insect-pollinated plants in Britain and the Netherlands. Science, 313, 351-354.

Bignal, E.M. \& McCracken, D.I. (1996) Low-intensity farming systems in the conservation of the countryside. Journal of Applied Ecology, 33, 413-424.

Branquart, E. \& Hemptinne, J.L. (2000) Selectivity in the exploitation of floral resources by 
hoverflies (Diptera : Syrphinae). Ecography, 23, 732-742.

Brody, A.K. \& Mitchell, R.J. (1997) Effects of experimental manipulation of inflorescence size on pollination and pre-dispersal seed predation in the hummingbird-pollinated plant Ipomopsis aggregata. Oecologia, 110, 86-93.

Brys, R., Jacquemyn, H., Endels, P., Hermy, M. \& de Blust, G. (2003) The relationship between reproductive success and demographic structure in remnant populations of Primula veris. Acta Oecologica, 24, 247-253.

Buchmann, S.L. \& Nabhan, G.P. (1997) The forgotten pollinators. Island Press, Washington, DC.

Burd, M. (1994) Bateman principle and plant reproduction - the role of pollen limitation in fruit and seed set. Botanical Review, 60, 83-139.

Burgio, G. \& Sommaggio, D. (2007) Syrphids as landscape bioindicators in Italian agroecosystems. Agriculture Ecosystems \& Environment, 120, 416-422.

Burnham, K.P. \& Anderson, D.R. (2002) Model selection and multimodel inference: a practical information-theoretic approach. Springer-Verlag, New York.

Cane, J.H. (2001) Habitat fragmentation and native bees: a premature verdict? Conservation Ecology, 5, art. no. 3.

Cane, J.H., Minckley, R.L., Kervin, L.J., Roulston, T.H. \& Williams, N.M. (2006) Complex responses within a desert bee guild (Hymenoptera: Apiformes) to urban habitat fragmentation. Ecological Applications, 16, 632-644.

Colwell, R.K. (2004) EstimateS, Version 7: Statistical estimation of species richness and shared species from samples (software and user's guide). http://viceroy.eeb.uconn.edu/EstimateS.

Cresswell, J.E. \& Osborne, J.L. (2004) The effect of patch size and separation on bumblebee foraging in oilseed rape: implications for gene flow. Journal of Applied Ecology, 41, 539546.

Cresswell, J.E., Osborne, J.L. \& Goulson, D. (2000) An economic model of the limits to foraging range in central place foragers with numerical solutions for bumblebees. 
Ecological Entomology, 25, 249-255.

Dafni, A., Kevan, P.G. \& Husband, B.C. (2005) Practical Pollination Ecology. Enviroquest, Cambridge, Ontario, Canada.

Duelli, P. \& Obrist, M.K. (2003) Regional biodiversity in an agricultural landscape: the contribution of seminatural habitat islands. Basic and Applied Ecology, 4, 129-138.

Dupont, Y.L. \& Nielsen, B.O. (2006) Species composition, feeding specificity and larval trophic level of flower-visiting insects in fragmented versus continuous heathlands in Denmark. Biological Conservation, 131, 475-485.

Ehrlén, J. (1996) Spatiotemporal variation in predispersal seed predation intensity. Oecologia, 108, 708-713.

Ellenberg, H. (1996) Vegetation Mitteleuropas mit den Alpen. Eugen Ulmer, Stuttgart.

Eriksson, O. \& Ehrlén, J. (1992) Seed and microsite limitation of recruitment in plant populations. Oecologia, 91, 360-364.

Ewers, R.M. \& Didham, R.K. (2006) Confounding factors in the detection of species responses to habitat fragmentation. Biological Reviews, 81, 117-142.

Fahrig, L. (2003) Effects of habitat fragmentation on biodiversity. Annual Review of Ecology Evolution and Systematics, 34, 487-515.

Fearn, G.M. (1973) Hippocrepis comosa L. Journal of Ecology, 61, 915-926.

Fischer, M. \& Stöcklin, J. (1997) Local extinctions of plants in remnants of extensively used calcareous grasslands 1950-1985. Conservation Biology, 11, 727-737.

Fischer, S.F., Poschlod, P. \& Beinlich, B. (1996) Experimental studies on the dispersal of plants and animals on sheep in calcareous grasslands. Journal of Applied Ecology, 33, 1206-1222.

Fontaine, C., Dajoz, I., Meriguet, J. \& Loreau, M. (2006) Functional diversity of plantpollinator interaction webs enhances the persistence of plant communities. PLOS Biology, 4, 1-7.

Fuller, R.M. (1987) The changing extent and conservation interest of lowland grasslands in 
England and Wales - a review of grassland surveys 1930-84. Biological Conservation, 40, 281-300.

Gabriel, D., Roschewitz, I., Tscharntke, T. \& Thies, C. (2006) Beta diversity at different spatial scales: Plant communities in organic and conventional agriculture. Ecological Applications, 16, 2011-2021.

Garve, E. (1994) Atlas der gefährdeten Farn- und Blütenpflanzen in Niedersachsen und Bremen. Kartierung 1982-1992. Hannover.

Gathmann, A. \& Tscharntke, T. (2002) Foraging ranges of solitary bees. Journal of Animal Ecology, 71, 757-764.

Gegear, R.J. \& Laverty, T.M. (2005) Flower constancy in bumblebees: a test of the trait variability hypothesis. Animal Behaviour, 69, 939-949.

Gotelli, N.J. \& Colwell, R.K. (2001) Quantifying biodiversity: procedures and pitfalls in the measurement and comparison of species richness. Ecology Letters, 4, 379-391.

Goulson, D. (2000) Why do pollinators visit proportionally fewer flowers in large patches? Oikos, 91, 485-492.

Goulson, D., Ollerton, J. \& Sluman, C. (1997) Foraging strategies in the small skipper butterfly, Thymelicus flavus: When to switch? Animal Behaviour, 53, 1009-1016.

Goulson, D. \& Wright, N.P. (1998) Flower constancy in the hoverflies Episyrphus balteatus (Degeer) and Syrphus ribesii (L.) (Syrphidae). Behavioral Ecology, 9, 213-219.

Haila, Y. (2002) A conceptual genealogy of fragmentation research: From island biogeography to landscape ecology. Ecological Applications, 12, 321-334.

Hanski, I., Alho, J. \& Moilanen, A. (2000) Estimating the parameters of survival and migration of individuals in metapopulations. Ecology, 81 , 239-251.

Haslett, J.R. (1989) Adult feeding by holometabolous insects: pollen and nectar as complementary nutrient sources for Rhingia campestris (Diptera: Syrphidae). Oecologia, 81, 361-363.

Hegland, S.J. \& Boeke, L. (2006) Relationships between the density and diversity of floral 
resources and flower visitor activity in a temperate grassland community. Ecological Entomology, 31, 532-538.

Helm, A., Hanski, I. \& Partel, M. (2006) Slow response of plant species richness to habitat loss and fragmentation. Ecology Letters, 9, 72-77.

Hendrickx, F., Maelfait, J.P., Van Wingerden, W. , Schweiger, O., Speelmans, M., Aviron, S., Augenstein, I., Billeter, R., Bailey, D., Bukacek, R., Burel, F., Diekötter, T., Dirksen, J., Herzog, F., Liira, J., Roubalova, M., Vandomme, V. \& Bugter, R. (2007) How landscape structure, land-use intensity and habitat diversity affect components of total arthropod diversity in agricultural landscapes. Journal of Applied Ecology, 44, 340-351.

Hennenberg, K.J. \& Bruelheide, H. (2003) Ecological investigations on the northern distribution range of Hippocrepis comosa L. in Germany. Plant Ecology, 166, 167-188.

Hines, H.M. \& Hendrix, S.D. (2005) Bumble bee (Hymenoptera: Apidae) diversity and abundance in tallgrass prairie patches: Effects of local and landscape floral resources. Environmental Entomology, 34, 1477-1484.

Holt, R.D., Lawton, J.H., Polis, G.A. \& Martinez, N.D. (1999) Trophic rank and the speciesarea relationship. Ecology, 80, 1495-1504.

Holzschuh, A., Steffan-Dewenter, I., Kleijn, D. \& Tscharntke, T. (2007) Diversity of flowervisiting bees in cereal fields: effects of farming system, landscape composition and regional context. Journal of Applied Ecology, 44, 41-49.

Hopkins, A. \& Wilkins, R.J. (2006) Temperate grassland: key developments in the last century and future perspectives. Journal of Agricultural Science, 144, 503-523.

Inghe, O. \& Tamm, C.O. (1988) Survival and flowering of perennial herbs. V. Patterns of flowering. Oikos, 51, 203-219.

Ivey, C.T., Martinez, P. \& Wyatt, R. (2003) Variation in pollinator effectiveness in swamp milkweed, Asclepias incarnata (Apocynaceae). American Journal of Botany, 90, 214-225.

Jennersten, O. \& Nilsson, S.G. (1993) Insect flower visitation frequency and seed production in relation to patch size of Viscaria vulgaris (Caryophyllaceae). Oikos, 68, 283-292.

Jervis, M. \& Kidd, N. (1996) Insect natural enemies - practical approaches to their study and 
evaluation. Chapman \& Hall, London.

Kearns, C.A., Inouye, D.W. \& Waser, N.M. (1998) Endangered mutualisms: The conservation of plant-pollinator interactions. Annual Review of Ecology and Systematics, 29, 83-112.

Kéry, M., Matthies, D. \& Schmid, B. (2003) Demographic stochasticity in population fragments of the declining distylous perennial Primula veris (Primulaceae). Basic and Applied Ecology, 4, 197-206.

Kéry, M., Matthies, D. \& Spillmann, H.H. (2000) Reduced fecundity and offspring performance in small populations of the declining grassland plants Primula veris and Gentiana lutea. Journal of Ecology, 88, 17-30.

Kleijn, D. \& van Langevelde, F. (2006) Interacting effects of landscape context and habitat quality on flower visiting insects in agricultural landscapes. Basic and Applied Ecology, 7, 201-214.

Klein, A.-M., Vaissiere, B., Cane, J.H., Steffan-Dewenter, I., Cunningham, S.A., Kremen, C. \& Tscharntke, T. (2007) Importance of pollinators in changing landscapes for world crops. Proceedings of the Royal Society of London Series B-Biological Sciences, 274, 303-313.

Krauss, J., Steffan-Dewenter, I. \& Tscharntke, T. (2003) How does landscape context contribute to effects of habitat fragmentation on diversity and population density of butterflies? Journal of Biogeography, 30, 889-900.

Krebs, C.J. (1989) Ecological Methodology. Harper Collins, New York.

Kunin, W.E. (1993) Sex and the single mustard: Population density and pollinator behavior effects on seed-set. Ecology, 74, 2145-2160.

LaSalle, J. \& Gauld, I.D. (1993) Hymenoptera: their diversity, and their impact on the diversity of other organisms. Hymenoptera and biodiversity (eds. J. LaSalle \& I. D. Gauld), pp. 1-26. CAB International, Wallingford.

Leimu, R., Syrjänen, K., Ehrlén, J. \& Lehtilä, K. (2002) Pre-dispersal seed predation in Primula veris: among-population variation in damage intensity and selection on flower number. Oecologia, 133, 510-516. 
Lennartsson, T. (2002) Extinction thresholds and disrupted plant-pollinator interactions in fragmented plant populations. Ecology, 83, 3060-3072.

Lindborg, R., Cousins, S.A.O. \& Eriksson, O. (2005) Plant species response to land use change - Campanula rotundifolia, Primula veris and Rhinanthus minor. Ecography, 28, 29-36.

MacArthur, R.H. \& Wilson, E.O. (1967) The theory of island biogeography. Princeton University, Princeton.

Matsumura, C. \& Washitani, I. (2000) Effects of population size and pollinator limitation on seed-set of Primula sieboldii populations in a fragmented landscape. Ecological Research, 15, 307-322.

Matthies, D., Bräuer, I., Maibon, W. \& Tscharntke, T. (2004) Population size and the risk of local extinction: empirical evidence from rare plants. Oikos, 105, 481-488.

Mauss, V. (1987) Bestimmungsschlüssel für die Hummeln der Bundesrepublik Deutschland. Deutscher Jugendbund für Naturbeobachtung, Hamburg.

Menges, E. (1991) The application of minimum viable population theory to plants. Genetics and conservation of rare plants (eds D. Falk\& K. Holsinger), pp. 45-61. Oxford University Press, Oxford.

Monteil, C. (2006) A Species Selection Tool for the "Syrph the Net" database. Syrph the Net on CD, Issue 5. The database of European Syrphidae (eds M. C. D. Speight, E. Castella, J.-P. Sarthou, \& C. Monteil), Syrph the Net Publications, Dublin.

Morandin, L.A., Winston, M.L., Abbott, V.A. \& Franklin, M.T. (2007) Can pastureland increase wild bee abundance in agriculturally intense areas? Basic and Applied Ecology, 8, $117-124$.

Mustajärvi, K., Siikamäki, P., Rytkönen, S. \& Lammi, A. (2001) Consequences of plant population size and density for plant-pollinator interactions and plant performance. Journal of Ecology, 89, 80-87.

Niehoff, B. \& Poehling, H.M. (1995) Population dynamics of aphids and syrphid larvae in winter wheat treated with different rates of pirimicarb. Agriculture Ecosystems \& Environment, 52, 51-55. 
Öckinger, E. \& Smith, H.G. (2006) Landscape composition and habitat area affects butterfly species richness in semi-natural grasslands. Oecologia, 149, 526-534.

Ouin, A., Sarthou, J.P., Bouyjou, B., Deconchat, M., Lacombe, J.P. \& Monteil, C. (2006) The species-area relationship in the hoverfly (Diptera, Syrphidae) communities of forest fragments in southern France. Ecography, 29, 183-190.

Philippi, G. (1993) Primulaceae. Die Farn- und Blütenpflanzen Baden-Württembergs. Band 2 (eds. O. Sebald, S. Seybold \& G. Philippi), pp. 377-416. Eugen Ulmer Verlag, Stuttgart.

Pinheiro, J.C. \& Bates, D.M. (2000) Mixed-effect models in S and S-PLUS. Springer, New York.

Poschlod, P. \& WallisDeVries, M.F. (2002) The historical and socioeconomic perspective of calcareous grasslands - lessons from the distant and recent past. Biological Conservation, 104, 361-376.

Potts, S.G., Vulliamy, B., Dafni, A., Ne'eman, G. \& Willmer, P. (2003) Linking bees and flowers: How do floral communities structure pollinator communities? Ecology, 84, 26282642.

Powell, A.H. \& Powell, G.V.N. (1987) Population dynamics of male euglossine bees in Amazonian forest fragments. Biotropica, 19, 176-179.

Pías, B., Salvande, M. \& Guitián, P. (2007) Variation in predispersal losses in reproductive potential in rowan (Sorbus aucuparia L. Rosaceae) in the NW Iberian Peninsula. Plant Ecology, 188, 191-203.

R Development Core Team (2006) R: A Language and Environment for Statistical Computing. The R Foundation for Statistical Computing, Vienna, Austria.

Rand, T.A. \& Louda, S.A. (2006) Spillover of agriculturally subsidized predators as a potential threat to native insect herbivores in fragmented landscapes. Conservation Biology, 20, 1720-1729.

Rathcke, B. (1983) Competition and facilitation among plants for pollination. Pollination biology (ed L. Real), pp. 305-329. Academic Press, Orlando.

Rathcke, B.J. \& Jules, E.S. (1993) Habitat fragmentation and plant-pollinator interactions. 
Current Science, 65, 273-277.

Ricketts, T.H. (2001) The matrix matters: Effective isolation in fragmented landscapes. American Naturalist, 158, 87-99.

Ricklefs, R.E. \& Lovette, I.J. (1999) The roles of island area per se and habitat diversity in the species-area relationships of four Lesser Antillean faunal groups. Journal of Animal Ecology, 68, 1142-1160.

Rosenzweig, M.L. (1995) Species diversity in space and time. Cambridge University Press, Cambridge.

Roubik, D.W. (2001) Ups and downs in pollinator populations: When is there a decline? Conservation Ecology, 5.

Sadeghi, H. \& Gilbert, F. (2000) Aphid suitability and its relationship to oviposition preference in predatory hoverflies. Journal of Animal Ecology, 69, 771-784.

Scheuchl, E. (1996) Illustrierte Bestimmungstabellen der Wildbienen Deutschlands und Österreichs - Band II: Megachilidae - Melittidae. Eigenverlag, Landshut.

Scheuchl, E. (2000) Illustrierte Bestimmungstabellen der Wildbienen Deutschlands und Österreichs - Band I: Anthophoridae. Eigenverlag, Velden.

Schmid, B., Hector, A., Huston, M.A., Inchausti, P., Nijs, I., Leadley, P.W. \& Tilman, D. (2002) The design and analysis of biodiversity experiments. Biodiversity and ecosystem functioning - synthesis and perspectives (eds M. Loreau, S. Naeem, \& P. Inchausti), Oxford University Press, Oxford.

Schmid-Egger, C. \& Scheuchl, E. (1997) Illustrierte Bestimmungstabellen der Wildbienen Deutschlands und Österreichs - Band III: Andrenidae. Eigenverlag, Velden.

Schoereder, J.H., Galbiati, C., Ribas, C.R., Sobrinho, T.G., Sperber, C.F., DeSouza, O. \& Lopes-Andrade, C. (2004) Should we use proportional sampling for species-area studies? Journal of Biogeography, 31, 1219-1226.

Schweiger, O., Musche, M., Bailey, D., Billeter, R., Diekötter, T., Hendrickx, F., Herzog, F., Liira, J., Maelfait, J.P., Speelmans, M. \& Dziock, F. (2007) Functional richness of local hoverfly communities (Diptera, Syrphidae) in response to land use across temperate 
Europe. Oikos, 116, 461-472.

Shahabuddin, G. \& Ponte, C.A. (2005) Frugivorous butterfly species in tropical forest fragments: correlates of vulnerability to extinction. Biodiversity and Conservation, 14, 1137-1152.

Sih, A. \& Baltus, M.S. (1987) Patch size, pollinator behavior, and pollinator limitation in catnip. Ecology, 68, 1679-1690.

Speight, M.C.D. (2006) Species accounts of European Syrphidae (Diptera), Ferrara 2006. Syrph the Net on CD, Issue 5. The database of European Syrphidae (eds M. C. D. Speight, E. Castella, J.-P. Sarthou, \& C. Monteil), Syrph the Net Publications, Dublin.

Speight, M.C.D., Monteil, C., Castella, E. \& Sarthou, J.-P. (2006) StN Ferrara 2006. Syrph the Net on CD, Issue 5. The database of European Syrphidae (eds M. C. D. Speight, E. Castella, J.-P. Sarthou, \& C. Monteil), Syrph the Net Publications, Dublin.

Steffan-Dewenter, I. (2003) Importance of habitat area and landscape context for species richness of bees and wasps in fragmented orchard meadows. Conservation Biology, 17, 1036-1044.

Steffan-Dewenter, I., Klein, A.M., Gaebele, V., Alfert, T. \& Tscharntke, T. (2006) Bee diversity and plant-pollinator interactions in fragmented landscapes. Plant-pollinator interactions - from specialization to generalization (eds N. M. Waser \& J. Ollerton), pp. 387-407. The University of Chicago Press, Chicago.

Steffan-Dewenter, I. \& Kuhn, A. (2003) Honeybee foraging in differentially structured landscapes. Proceedings of the Royal Society of London Series B-Biological Sciences, 270, 569-575.

Steffan-Dewenter, I., Münzenberg, U., Bürger, C., Thies, C. \& Tscharntke, T. (2002) Scaledependent effects of landscape context on three pollinator guilds. Ecology, 83, 1421-1432.

Steffan-Dewenter, I., Münzenberg, U. \& Tscharntke, T. (2001) Pollination, seed set and seed predation on a landscape scale. Proceedings of the Royal Society of London Series BBiological Sciences, 268, 1685-1690.

Steffan-Dewenter, I. \& Tscharntke, T. (2000) Butterfly community structure in fragmented habitats. Ecology Letters, 3, 449-456. 
Steffan-Dewenter, I. \& Tscharntke, T. (2002) Insect communities and biotic interactions on fragmented calcareous grasslands - a mini review. Biological Conservation, 104, 275-284.

Steven, J.C., Rooney, T.P., Boyle, O.D. \& Waller, D.M. (2003) Density-dependent pollinator visitation and self-incompatibility in upper Great Lakes populations of Trillium grandiflorum. Journal of the Torrey Botanical Society, 130, 23-29.

Stoate, C., Boatman, N.D., Borralho, R.J., Carvalho, C.R., De Snoo, G.R. \& Eden, P. (2001) Ecological impacts of arable intensification in Europe. Journal of Environmental Management, 63, 337-365.

Sugiura, N. (1996) Pollination of the orchid Epipactis thunbergii by syrphid flies (Diptera: Syrphidae). Ecological Research, 11, 249-255.

Talavera, S., Bastida, F., Ortiz, P.L. \& Arista, M. (2001) Pollinator attendance and reproductive success in Cistus libanotis L. (Cistaceae). International Journal of Plant Sciences, 162, 343-352.

Tamm, C.O. (1972) Survival and flowering of perennial herbs. III. Behavior of Primula veris on permanent plots. Oikos, 23, 159-\&.

Tenhumberg, B. \& Poehling, H.M. (1995) Syrphids as natural enemies of cereal aphids in Germany: Aspects of their biology and efficacy in different years and regions. Agriculture Ecosystems \& Environment, 52, 39-43.

Tilman, D., Fargione, J., Wolff, B., D'antonio, C., Dobson, A., Howarth, R., Schindler, D., Schlesinger, W.H., Simberloff, D. \& Swackhamer, D. (2001) Forecasting agriculturally driven global environmental change. Science, 292, 281-284.

Tscharntke, T. \& Brandl, R. (2004) Plant-insect interactions in fragmented landscapes. Annual Review of Entomology, 49, 405-430.

Tscharntke, T., Klein, A.M., Kruess, A., Steffan-Dewenter, I. \& Thies, C. (2005) Landscape perspectives on agricultural intensification and biodiversity - ecosystem service management. Ecology Letters, 8, 857-874.

Tscharntke, T., Steffan-Dewenter, I., Kruess, A. \& Thies, C. (2002) Characteristics of insect populations on habitat fragments: A mini review. Ecological Research, 17, 229-239. 
van Veen, M.P. (2004) Hoverflies of Northwest Europe - Identification keys to the Syrphidae. KNNV publishing, Utrecht.

Vance, N.C., Bernhardt, P. \& Edens, R.M. (2004) Pollination and seed production in Xerophyllum tenax (Melanthiaceae) in the cascade range of central Oregon. American Journal of Botany, 91, 2060-2068.

Vitousek, P.M. (1994) Beyond global warming - ecology and global change. Ecology, 75, 1861-1876.

Voggesberger, M. (1992) Fabaceae. Die Farn- und Blütenpflanzen Baden-Württembergs. Band 3 (O. Sebald, S. Seybold \& G. Philippi), pp. 288-450. Eugen Ulmer, Stuttgart.

von Hagen, E. \& Aichhorn, A. (2003) Hummeln. Bestimmen, ansiedeln, vermehren, schützen. Fauna Verlag, Nottuln.

Waites, A.R. \& Agren, J. (2004) Pollinator visitation, stigmatic pollen loads and amongpopulation variation in seed set in Lythrum salicaria. Journal of Ecology, 92, 512-526.

WallisDeVries, M.F., Poschlod, P. \& Willems, J.H. (2002) Challenges for the conservation of calcareous grasslands in northwestern Europe: integrating the requirements of flora and fauna. Biological Conservation, 104, 265-273.

Walther-Hellwig, K. \& Frankl, R. (2000) Foraging habitats and foraging distances of bumblebees, Bombus spp. (Hym., Apidae), in an agricultural landscape. Journal of Applied Entomology, 124, 299-306.

Waser, N.M., Chittka, L., Price, M.V., Williams, N.M. \& Ollerton, J. (1996) Generalization in pollination systems, and why it matters. Ecology, 77, 1043-1060.

Watling, J.I. \& Donnelly, M.A. (2006) Fragments as islands: a synthesis of faunal responses to habitat patchiness. Conservation Biology, 20, 1016-1025.

Wedderburn, F. \& Richards, A.J. (1990) Variation in within-morph incompatibility inhibition sites in heteromorphic Primula L. New Phytologist, 116, 149-162.

Weibull, A.C., Bengtsson, J. \& Nohlgren, E. (2000) Diversity of butterflies in the agricultural landscape: the role of farming system and landscape heterogeneity. Ecography, 23, 743750. 
Westphal, C., Steffan-Dewenter, I. \& Tscharntke, T. (2003) Mass flowering crops enhance pollinator densities at a landscape scale. Ecology Letters, 6, 961-965.

Westphal, C., Steffan-Dewenter, I. \& Tscharntke, T. (2006) Bumblebees experience landscapes at different spatial scales: possible implications for coexistence. Oecologia, 149, 289-300.

Westrich, P. (1989a) Die Wildbienen Baden-Württembergs. Allgemeiner Teil: Lebensräume, Verhalten, Ökologie und Schutz. Eugen Ulmer, Stuttgart.

Westrich, P. (1989b) Die Wildbienen Baden-Württembergs. Spezieller Teil: die Gattungen und Arten. Eugen Ulmer, Stuttgart.

Whittaker, R.J. (1998) Island Biogeography - Ecology, Evolution, and Conservation. Oxford University Press, Oxford.

Wilcock, C. \& Neiland, R. (2002) Pollination failure in plants: why it happens and when it matters. Trends in Plant Science, 7, 270-277.

Wolf, A.T. \& Harrison, S.P. (2001) Effects of habitat size and patch isolation on reproductive success of the serpentine morning glory. Conservation Biology, 15, 111-121.

Woodell, S.R.J. (1960) What pollinates Primulas? New Scientist, 8, 568-571.

Wratten, S.D., Bowie, M.H., Hickman, J.M., Evans, A.M., Sedcole, J.R. \& Tylianakis, J.M. (2003) Field boundaries as barriers to movement of hover flies (Diptera: Syrphidae) in cultivated land. Oecologia, 134, 605-611.

Zimmerman, M. (1981) Patchiness in the dispersion of nectar resources: probable causes. Oecologia, 49, 154-157. 


\section{SUMMARY}

Agricultural intensification has caused a substantial decline of once common seminatural habitats in the agricultural landscape. Many calcareous grasslands, one of the most species-rich habitats in central Europe harbouring many xero- and thermophilic plant and animal species, are left for succession because of the abandonment of traditional land-use practises such as sheep- or goat-herding. The remaining small and isolated habitat fragments in a matrix of an unsuitable, structurally poor landscape might fail to offer sufficient foraging and nesting resources for pollinator communities. Fragmentation may therefore disrupt plantpollinator interactions on semi-natural habitats potentially causing pollination limitation of calcareous grassland plant species and reducing their reproductive success.

In the first part of this study, the effects of habitat and landscape factors on species richness and abundance of two important pollinator groups, i.e. bees (Hymenoptera: Apiformes) and hover flies (Diptera: Syrphidae), in fragmented calcareous grasslands were analysed. In the second part, the reproductive success of two endangered calcareous grassland species, Primula veris and Hippocrepis comosa, was determined in relation to patch, population, and landscape factors.

We assessed pollinator communities on 32 calcareous grasslands around the city of Göttingen in Germany differing in size, resource availability, and landscape context. During six transect walks from April to September 2004, 4707 bees out of 110 species and 3560 hoverflies out of 75 species groups were recorded. Richness of bee and hoverfly species increased strongly with increasing habitat size. Small and solitary bees especially exhibited strong species-area relationships whereas large bees, social bees, and cuckoo bees were less influenced by habitat loss. Hoverflies and bees, especially social bees, further depended on resource availability. Bumble bees and social halictid bees can establish large colonies on grassland fragments with abundant nectar and pollen resources. Increasing complexity of the landscape immediately surrounding the calcareous grasslands (radius $250 \mathrm{~m}$ ) also positively influenced species richness of bees and hoverflies. Whereas abundances of bees increased in complex landscapes, more hoverfly individuals were found in homogeneous landscapes. This can be attributed to the high number of hoverflies with aphidophagous larvae. Hoverflies such as Episyrphus balteatus, whose larvae predate crop aphids, occur in large numbers in homogeneous landscapes because of the large amount of available annual crop fields. Similar effects were observed in obligate forest hoverflies as more individuals were found on 
calcareous grasslands with a high percentage cover of forest in the surrounding landscape. Unlike overall species richness, the abundance of hoverflies was determined by the surrounding landscape at larger scales up to $1500 \mathrm{~m}$. Thus, crop and forest dwelling hoverflies exhibit good dispersal abilities and can cover large foraging distances.

Pollination and reproductive success of the two self-incompatible, declining calcareous grassland species Primula veris and Hippocrepis comosa were analysed on small, medium and large patches in 15 differently sized calcareous grassland fragments surrounded by landscape matrices of differing complexity. Between April and September 2005, flower visitors were observed during three 15-minute observations on 44 patches of $P$. veris and 54 patches of $H$. comosa. Fruits of each species were collected after seed ripening to determine seed set per fruit and assess the predation rate by seed predators. To test for pollination limitation, we performed pollination experiments comparing seed set per fruit of hand- versus open-pollinated flowers. For a comparative analysis, data from a similar study in 2000 was drawn on. Pollinators were most abundant on large patches of P. veris and $H$. comosa, on large calcareous grassland fragments, and in diverse landscapes. Whereas seed predation was not effective in $H$. comosa, $P$. veris fruits had predation rates up to $100 \%$, experiencing the strongest predation on large calcareous grassland fragments. Both grassland species showed evidence of pollination limitation because hand-pollinated flowers set more seeds per fruit than open-pollinated flowers. Seed set was strongly reduced in small patches of $P$. veris and in $H$. comosa patches with low visitation rates.

The results of this study show that communities of bee and hoverfly pollinators are strongly affected by the loss of semi-natural habitat. Moreover, a diverse landscape around the habitat fragments and ample resource availability in the calcareous grasslands were of importance for pollinators. This was further reflected in the reduced abundance of flower visitors of $P$. veris and $H$. comosa in small patches, small grassland fragments, and homogeneous landscapes which ultimately resulted in a reduced reproductive success. In order to conserve pollinator communities and maintain plant-pollinator interactions in agricultural landscapes, conservation efforts should include the preservation of large, heterogeneous, and flower rich calcareous grasslands. A diverse landscape surrounding the semi-natural habitats offering hedgerows, flowering strips, orchard meadows, extensively managed grasslands, etc. will add to the permeability of the landscape and offer additional habitats for pollinators. 


\section{ZUSAMMENFASSUNG}

Der Landnutzungswandel einhergehend mit der Intensivierung der Landwirtschaft und der Aufgabe unrentabler Flächen führte während der letzten Jahrzehnte zu einer Abnahme von naturnahen Habitaten in der Agrarlandschaft. Sehr artenreiche Habitate wie z.B. Kalkmagerrasen, die viele wärme- und trockenliebende Tier- und Pflanzenarten beherbergen, werden durch die Aufgabe traditioneller Hütewirtschaft der Sukzession überlassen, so dass nur kleine, isolierte Fragmente in einer homogenen Agrarlandschaft übrig bleiben. Diese kleinen Magerrasenfragmente bieten nur wenig Nahrungs- und Nistressourcen für Bestäubergemeinschaften und sind daher von einem Bestäubermangel bedroht. Dies führt zu gestörten Pflanze-Bestäuber-Interaktionen auf den kleinen Fragmenten und gefährdet letztlich den Reproduktionserfolg der speziellen Magerrasenflora.

Die vorliegende Arbeit gliedert sich in zwei Bereiche: Zum einen wurde der Einfluss von Habitat- und Landschaftsfaktoren auf die Lebensgemeinschaften zweier wichtiger Bestäubergruppen, Bienen (Hymenoptera: Apiformes) und Schwebfliegen (Diptera: Syrphidae) auf fragmentierten Kalkmagerrasen untersucht. Zum anderen wurde der Reproduktionserfolg zweier gefährdeter Kalkmagerrasenpflanzen, Primula veris und Hippocrepis comosa, in Abhängigkeit von Populations- und Landschaftsfaktoren und der Bestäuberbesuche analysiert.

Die Aufnahme der Bestäubergemeinschaften erfolgte auf 32 Kalkmagerrasen im Raum Göttingen, die sich in ihrer Nahrungsverfügbarkeit, Größe und Diversität der umgebenden Landschaft unterscheiden. Mittels sechs Transektbegehungen von April bis September 2004 wurden 4707 Bienen aus 110 Arten und 3560 Schwebfliegen aus 75 Artengruppen erfasst. Der Artenreichtum der Bienen und Schwebfliegen war sehr stark von der Größe der Magerrasenfragmente abhängig. Insbesondere kleine und solitäre Bienen zeigten starke Art-Areal-Beziehungen, während große Bienenarten, soziale Bienen und Kuckucksbienen weniger stark auf den Habitatverlust reagierten. Die Ressourcenverfügbarkeit hatte einen positiven Einfluss auf die Schwebfliegen und Bienen, besonders auffällig war der positive Effekt der Blühdichte auf das Vorkommen der sozialen Bienen; Hummeln und soziale Furchenbienen können auf den Kalkmagerrasen, die viele Pollen- und Nektarressourcen zur Verfügung stellen, besonders individuenstarke Kolonien ausbilden. Weiterhin wirkte sich die Diversität der umgebenden Landschaft positiv auf die Bienen- und Schwebfliegenarten aus. Besonders war hierbei die Landschaft in unmittelbarer 
Nähe zum Magerrasen (250 m Radius) von Bedeutung. Während auch die Individuenzahlen der Bienen in komplexen Landschaften anstiegen, wurden mehr Schwebfliegen auf Magerrasen in ausgeräumten Landschaften gefunden. Dies kann auf den großen Anteil von Schwebfliegen mit aphidophager Larvalentwicklung zurückgeführt werden. Schwebfliegen wie Episyrphus balteatus, deren Larven sich von Blattläusen in Feldfrüchten ernähren, sind dort vermehrt anzutreffen, wo viele Ackerfrüchte angebaut werden, also in ausgeräumten Landschaften. Ebenso verhielt es sich mit den Schwebfliegen, deren Larvalentwicklung sich im Wald vollzieht; sie wurden vermehrt auf Magerrasen gefunden, die einen hohen Waldanteil in der umgebenden Landschaft hatten. Für das Vorkommen der Schwebfliegenindividuen war nicht die Landnutzung in unmittelbarer Nachbarschaft, sondern auf höheren Skalenebenen bis zu $1500 \mathrm{~m}$ von Bedeutung. Dies lässt auf hohe Fouragierdistanzen und Ausbreitungsfähigkeiten der Acker- und Waldschwebfliegen schließen.

Für die Untersuchungen zur Bestäubung und zum Reproduktionserfolg zweier bedrohter Magerrasenpflanzen wurden jeweils kleine, mittlere und große Teilpopulationen in Primula veris- und Hippocrepis comosa-Populationen auf 15 Kalkmagerrasen ausgewählt, die sich ebenfalls in ihrer Größe und in der Diversität der umgebenden Landschaft unterschieden. Zwischen April und Juni 2005 wurden die Bestäuber in jeder Teilpopulation von P. veris (44 Teilpopulationen) und $H$. comosa (54 Teilpopulationen) jeweils dreimal für 15 Minuten beobachtet. Fruchtstände beider Pflanzen wurden gesammelt, um den Samenansatz zu ermitteln und die Schädigung durch Samenprädatoren zu erfassen. Um herauszufinden, ob die untersuchten Arten bestäuberlimitiert sind, wurden Bestäubungsexperimente durchgeführt. Für eine vergleichende Auswertung wurden Daten einer ähnlichen Untersuchung aus dem Jahr 2000 herangezogen. Die meisten Bestäuber wurden in den großen Teilpopulationen beider Arten, auf großen Magerrasenfragmenten und in komplexen Landschaften beobachtet. Die Samenprädation spielte bei $H$. comosa keine Rolle, während es bei $P$. veris Prädationsraten von bis zu 100 Prozent gab, wobei die stärkste Samenprädation auf großen Kalkmagerrasen nachgewiesen wurde. Beide Arten zeigten Bestäuberlimitierung, d.h. zusätzlich handbestäubte Blüten hatten einen höheren Samenansatz als insektenbestäubte Blüten. Der Samenansatz war zudem signifikant reduziert in kleinen $P$. verisTeilpopulationen und in $H$. comosa-Teilpopulationen mit geringen Besuchsraten.

Die Ergebnisse dieser Arbeit haben gezeigt, dass Bestäubergemeinschaften stark von Habitatverlust betroffen sind. Auch die Landschaft, die die naturnahen Kalkmagerrasen umgibt, und die Ressourcenverfügbarkeit innerhalb der Habitate waren von Bedeutung. Dies 
spiegelte sich auch bei den Besuchern von $P$. veris und $H$. comosa wieder, die weniger häufig in kleinen Teilpopulationen, kleinen Magerrasenfragmenten und ausgeräumten Landschaften zu finden waren und schließlich auch im geringeren Reproduktionserfolg der Pflanzen. Um Bestäubergemeinschaften zu bewahren und Pflanze-Bestäuber-Interaktionen intakt zu halten, ist die Erhaltung und Pflege von großen, heterogenen und blütenreichen Kalkmagerrasen von zentraler Bedeutung. Eine strukturreiche Landschaft um die Kalkmagerrasen mit Strukturen wie Hecken, Blühstreifen und Wegrändern und diversen Landnutzungen wie Streuobstwiesen oder extensiv bewirtschafteten Grünländern trägt zur Permeabilität der Landschaft bei und bietet zusätzliche Lebensräume für Bestäuber. 


\section{ACKNOWLEDGEMENTS}

Ich möchte mich sehr herzlich bei Prof. Dr. Ingolf Steffan-Dewenter bedanken; für die Überlassung dieses interessanten und schönen Themas, für die hervorragende Betreuung und Unterstützung meiner Arbeit, von der Planung der Freilandarbeit bis zur Korrektur der Manuskripte und für den Optimismus, den er immer dabei verbreitete. Prof. Dr. Stefan Vidal danke ich, dass er sich freundlicherweise als Korreferent zur Verfügung gestellt hat.

Der EU danke ich für die finanzielle Unterstützung der Untersuchungen im Rahmen des FP 6 integrierten Projekts ALARM, GOCE-CT-2003-506675).

Die Mithilfe vieler Menschen, denen ich an dieser Stelle danken möchte, hat mir meine Arbeit sehr erleichtert:

Jochen Krauß hat in einer vorangehenden Untersuchung die Kalkmagerrasen ausgewählt und die GIS-Dateien erstellt. Bertram Preuschhof von der Unteren Naturschutzbehörde des Landkreises Göttingen, die Biologische Schutzgemeinschaft, der Arbeitskreis Heimische Orchideen und andere Naturschutzverbände gaben ihre Zustimmung für meine Untersuchungen. Die Besitzer und Pfleger der Kalkmagerrasen, insbesondere die Schäfer Anke Busch und Olaf Tiedgen und ihre Tiere waren sehr kooperativ bei der Datenerhebung. Bei den Transektbegehungen und Blütenbeobachtungen hatte ich tatkräftige Unterstützung von Frank Jauker. Susanne Schiele war in vielen praktischen Angelegenheiten immer hilfsbereit und hat mir dabei so einiges über sauberes Arbeiten beigebracht. Die Samen von Primula veris wurden von Julia Dolezil gezählt. Dr. Reiner Theunert und Paul-Walter Löhr übernahmen freundlicherweise die Bestimmung schwieriger Bienenarten, bzw. Schwebfliegen der Gattung Cheilosia. Plötzlich auftretende Rechnerprobleme wurden von Friedrich Sundmacher stets prompt behoben. Bei der Datenanalyse haben Carsten Dormann und Christoph Scherber die passenden Tests aus dem Hut gezaubert und mir dabei viel über Statistik beigebracht. Hilfreiche Kommentare zu Manuskripten gaben neben einigen anonymen Gutachtern Frank Jauker, Jim desLauriers und Marcelo Aizen.

Ihnen allen tausend Dank!

Weiterhin danke ich den Kollegen im ALARM-Projekt, besonders den „Pollinators“ für eine schöne Zusammenarbeit und für produktive und sehr unterhaltsame Tagungen. Ein großes Dankeschön auch an Prof. Dr. Teja Tscharntke für die herzliche Aufnahme in seine Arbeitsgruppe. Allen Mitarbeitern der Agrarökologie, insbesondere Stephanie Sobek, Ines Vollhardt, Catrin Westphal, Arno Kuhn, Andrea Holzschuh, Birte Waßmuth und Patrick 
Höhn möchte ich für die schöne Zeit während meiner Doktorarbeit danken, für die angenehme Arbeitsatmosphäre, die anregenden Diskussion, die enorme Hilfsbereitschaft, und für viele schöne Freizeitaktivitäten. Ein besonderer Dank gilt dabei meiner stets hilfsbereiten, fürsorglichen und vor allem vergnüglichen Zimmerkollegin Barbara Scheid.

Außerordentlich verbunden bin ich meinen Eltern dafür, dass ich bei ihnen immer auf ihr Verständnis und ihre volle Unterstützung zählen konnte. Und schließlich gilt mein Dank Frank Jauker; für seinen unermüdlichen Arbeitseinsatz am Wochenende, viele fachliche Diskussionen, reichlich aufmunternde Worte und schöne Zerstreuungen zur rechten Zeit. 


\section{PUBLICATIONS}

Meyer, B., Jauker, F. \& Steffan-Dewenter, I. (submitted) Contrasting responses of species richness and density of hoverflies (Diptera: Syrphidae) to agricultural land-use change.

Meyer, B., Gaebele, V. \& Steffan-Dewenter, I. (submitted) Patch and landscape effects on pollinator diversity and seed set of Hippocrepis comosa in an agricultural landscape.

Meyer, B., Gaebele, V. \& Steffan-Dewenter, I. (submitted) Linking flower visitation, seed set, and seed predation of Primula veris at multiple spatial scales.

Meyer, B., Krauss, J. \& Steffan-Dewenter, I. (in revision) Importance of life history traits for pollinator loss in fragmented calcareous grasslands.

Meyer, B., Steffan-Dewenter, I. \& Theunert, R. (2007) Megachile apicalis (SPINOLA, 1808), erster Nachweis aus Niedersachsen (Hymenoptera: Apidae). Bembix 24: 25-26.

Meyer, B. \& Steffan-Dewenter, I. (2006). Habitat size and landscape diversity affect wild bee communities in fragmented calcareous grasslands. Verhandlungen der Gesellschaft für Ökologie 36: 97.

Meyer, B. \& Steffan-Dewenter, I. (2006). Pollinator loss in fragmented calcareous grasslands. Abstracts Volume of the 91st Annual Meeting of the Ecological Society of America (ESA) in Memphis, Tennessee.

Meyer, B. \& Steffan-Dewenter, I. (2005). Pollinator diversity in fragmented calcareous grasslands. Verhandlungen der Gesellschaft für Ökologie 35: 133.

Meyer, B., Dauber, J. \& Wolters, V. (2004). Effects of patch and landscape factors on specialist beetle fauna on Scotch Broom (Cytisus scoparius). Verhandlungen der Gesellschaft für Ökologie 34: 79. 


\section{CURRICULUM VITAE}

\section{Birgit Meyer}

geboren am 05.10.1974

in Varel

\section{Promotion}

03/2004 - 07/2007 bei Prof. Dr. Ingolf Steffan-Dewenter am Fachgebiet Agrarökologie, Georg-August Universität Göttingen im Rahmen des EU-Projekts ALARM

\section{Studium}

10/1999 - 11/2003 Biologie an der Justus-Liebig-Universität Gießen, Ausbildungsschwerpunkte: Ökologie, Zoologie und Tierphysiologie, Diplom-Biologin (Note: 1,0$)$

Diplomarbeit: „Untersuchungen der Coleopterenfauna an Besenginster, Cytisus scoparius im Lahn-Dill-Bergland mit einer Bemerkung über die Arten mit carpophager Larvalentwicklung“

09/1998 - 06/1999 Biologie an der California State Polytechnic University, Pomona (GPA 4.0)

01/1996 - 07/1998 Biologie am Chaffey College, Rancho Cucamonga, Kalifornien (GPA 4.0)

\section{Schulbildung}

11/1987 - 06/1994 Lothar-Meyer-Gymnasium in Varel, Abitur 